University of Rhode Island

DigitalCommons@URI

Open Access Master's Theses

1982

\title{
INDUSTRIAL PARK DEVELOPMENT: AN OVERVIEW AND CASE STUDY OF MYLES STANDISH INDUSTRIAL PARK, TAUNTON, MASSACHUSETTS
}

Nils Bonde-Henriksen

University of Rhode Island

Follow this and additional works at: https://digitalcommons.uri.edu/theses

\section{Recommended Citation}

Bonde-Henriksen, Nils, "INDUSTRIAL PARK DEVELOPMENT: AN OVERVIEW AND CASE STUDY OF MYLES STANDISH INDUSTRIAL PARK, TAUNTON, MASSACHUSETTS" (1982). Open Access Master's Theses. Paper 374.

https://digitalcommons.uri.edu/theses/374

This Thesis is brought to you for free and open access by DigitalCommons@URI. It has been accepted for inclusion in Open Access Master's Theses by an authorized administrator of DigitalCommons@URI. For more information, please contact digitalcommons-group@uri.edu. 
INDUSTRIAL PARK DEVELOPMEITT:

AN OVERVIEW AND CASE STUDY OF MYLES STANDISH INDUSTRIAL PARK, TAUNTON, MASSACHUSETTS

BY

NILS BONDE-HENRIKSEN

A RESEARCH PROJECT SUBMITTED IN PARTIAL FULFILIMENT OF THE REQUIREASENTS FOR THE DEGREE OF MASTER OF COMMUNITY PLANNING

UNIVTRSITY OF RHODF ISLAND 1982 


\section{IAASTER OF COMUNITY PLANNING}

PESEARCH PROJECT

OF

NILS BONDE-HENRIKSEN

APPROVED:

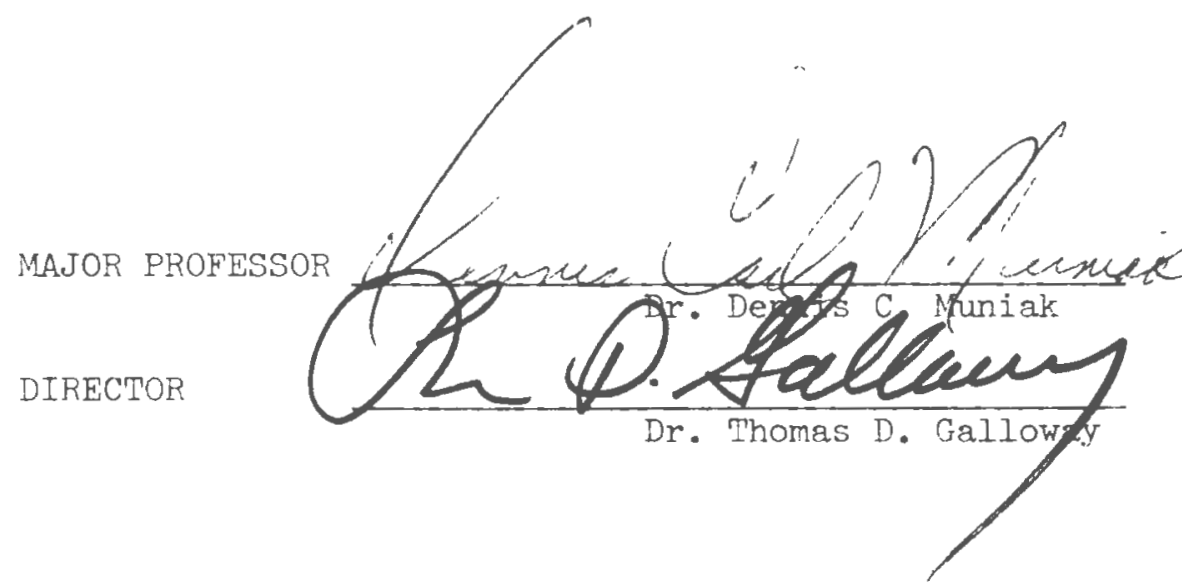




\section{TABLE OF CONTENTS}

Acknowledgements........................... i

I. OVFRVIEW AID HISTORY OF IINUSTRIAL PARKS

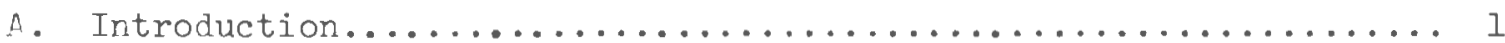

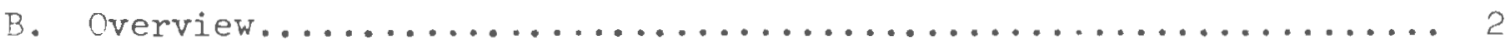

II. DEVELOPING THE INDUSTRIAL PARK

A. Preliminary Evaluations by Community and Industry...........13

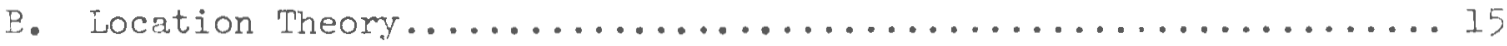

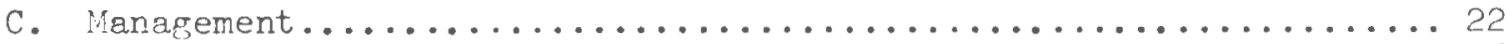

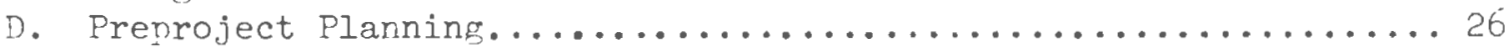

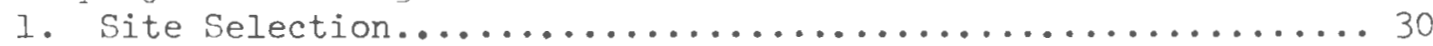

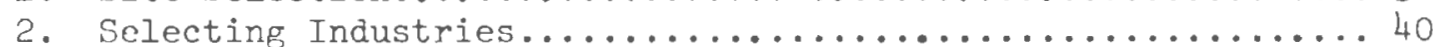

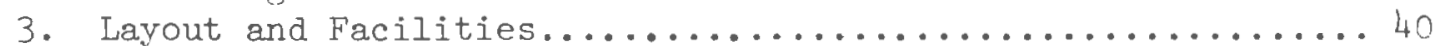

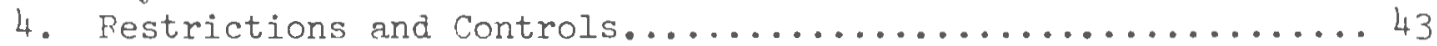

5. Factors Affecting Develonment Costs................. 45

6. Selling vs. Leasing.......................... 47

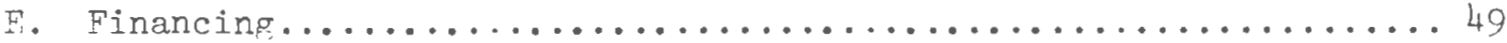

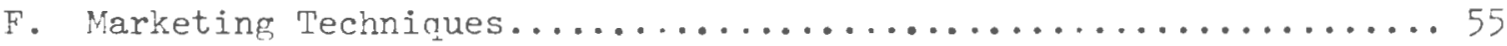

III. CASE STUDY OF MYLES STANDISH INDUSTRIAL

PARK, TAUNTON, MASSACHUSETTS

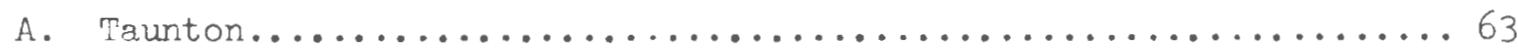

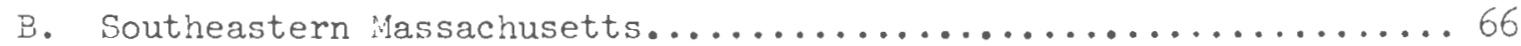

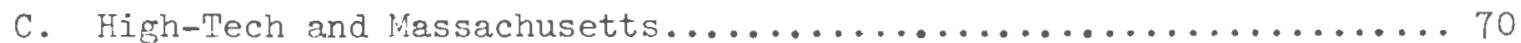

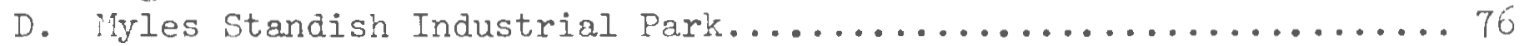

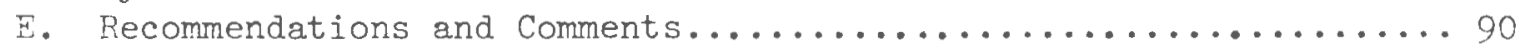

APPENDIX I. .................................... I-3

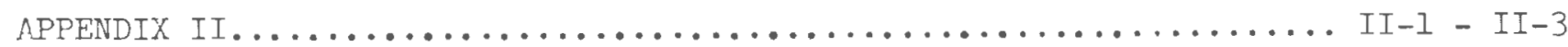

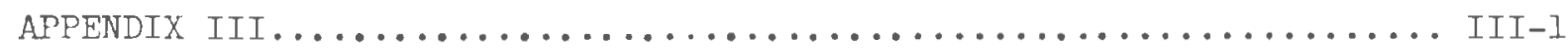

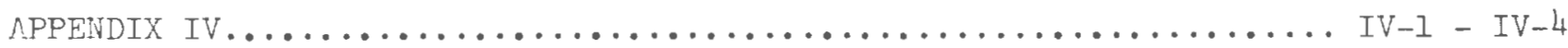




\section{ACKINOWLEDGF FENTS}

I would like to take this opportunity to thank my parents, Frik and Irna Bonde-Henriksen, and my Uncle Hans Bonde-Henriksen, for the supnort and encouragement which they have given me throughout the years.

Nlso, I'd like to offer my thanks and kest wishes to Ir. Dennis $\mathrm{C}$. :uniak, my advisor and confidant while at the University of Phode Island. His concern for his students was a breath of fresh air in the academic rorld and was appreciated by all. 


\section{INTRODUCTION}

There is an increasing realization in the United States that organized industrial parks may be a powerful tool for community industrial development. Many parks can be found which are well-planned and reflect a sophisticated awareness of the potential inherent in this form of development. Many others, however, reflect little effort to benefit from the mistakes of others, and exhibit serious and elementary defects.

This paper consists of two major sections. The first section describes the various factors involved in attracting suitable industry to a community, and details the steps needed for successful development of an industrial park. The second section consists of a study and analysis of Myles Standish Industrial Park in Taunton, Massachusetts. Myles Standish is evaluated using the criteria set forth in the first part of the paper. Comments and recommendations based on this evaluation are then offered.

The reader should understand that while this paper stresses the positive benefits of properly planned industrial parks, the risk of failure is inherent in industrial development programs which do not take these various factors into account. The proposition is set forth that taking these factors into account will help to assure the park's success; while the implied assumption is that not taking them into account will result in problems for the industrial park, the community, and possibly, the region. 
AN OVERVIEW OF INDUSTRIAL PARKS

An industrial park is a tract of land set aside for industrial purposes under the private management and control of the developer or investors. Typically it includes many designated sites. Since World War II the industrial park has come to typify the grouped siting of industrial activity within urban areas. During this period accelerated industrial growth and decentralization of economic activity throughout the United States have combined to give impetus to the expansion and acceptance of planned industrial developments. The term "industrial park" implies careful planning and brings to mind extensive low-rise buildings located in a landscaped setting of wide lawns, and interconnected by broad boulevards. Generally, the property has all the characteristics of the ideal industrial site, including installed utilities, highly accessible highway and rail connections, and finished grading.

Many parks can be found which are well-planned and reflect a sophisticated awareness of the potential inherent in this form of development. Many others, however, reflect little effort to benefit from the mistakes of others, and exhibit serious and elementary defects. This is at least partially due to the rapid changes in basic concepts and regulatory controls taking place in the field. Acceptance of the industrial park concept has grown rapidly during the last twenty-five years. A study conducted by the Industrial Development and Manufacturing Record substantiates this point. It indicated that in 1966 , eighty-five percent of the 1,102 industrial parks throughout the United States and Canada had been in existence ten years or less. I Industrial parks have not evolved in a steady progression. As new uses have been accommodated, some uses commonly included in earlier parks have been excluded. For example, heavy industry, once part of early planned industrial districts, is seldom provided for in the newest 
industrial parks. At the same time, however, new facilities such as offices, service areas, shonping centers, and recreational facilities are being added to enhance the convenience of the planned industrial neighborhood for tenants and visitors.

Because of their interest in encouraging industrial growth that would generate freight traffic, railroads played an important part in developing the early industrial districts in the United States. Even as late as 1952, most of the organized industrial districts in the country had been developed by the railroad companies. ${ }^{2}$ Between 1952 and 1957 the growing interest in planned location of industry caused a sharp increase in the number of parks and introduced new types of sponsorship. ${ }^{3}$ Railways declined in importance as sponsors, while sponsorship by private individuals and by agencies of government grew, especially at the municipal and regional level.

The largest single group of industrial districts is owned and operated privately for the purposes of making a profit. These have been developed by corporations, individual real estate brokers, contractors, architects, and others. Also noteworthy is the extent to which in recent years public development agencies, either directly or indirectly, have been increasingly influential in promoting parks. 4 These agencies have included municipalities and counties, port commissions, airport authorities, redevelopment authorities, housing authorities, and development commissions. Industrial foundations, or community development companies, have been utilized as instruments of development by local governments. There is increasing realization in the United States that organized industrial districts may be a powerful tool for community industrial development.

In order to compete effectively in the market, the industrial park must provide adequate facilities for the industrial user seeking space. The land should be in the form of serviced sites, and not simply undeveloped acerage. Minimum 
standards must be established so that the sites will be competitively attractive in the market. This means at least controlling the size and shape of lots and the use of the land, for the protection of current and prospective users, the developer, and the community.

The industrial park offers, as a minimum, a site "package" to the potential industrial user, along with protection of the investment in the site. The amenities and site improvements offered include at least the following: (a) good location, (b) utilities, (c) transportation, (d) services.

Industrial parks are most attractive to distributive or warehousing activities. Distribution is better suited to the locational amenities of industrial parks, and generally better able to pay premium prices for prime locations. Typically, these activities do not generate nuisances such as noise, odor, and smoke which are characteristic of certain industrial processes. Proper planning makes possible the accommodation of vehicular traffic which is usually the biggest problem generated by a warehouse and distribution park. In addition, these activities constitute an easily identifiable group of uses because most major material corporations require regional distribution facilities.

Industrial parks also are attractive to industrial service organizations and assembly-distribution type industries. The latter would include activities such as bakeries or candy plants, or the assembly, storage, and distribution of final products. Least appropriate for most industrial parks are fabricating or processing firms with relatively large land requirements and relatively little interest in the speed of delivery that distributive users are seeking.

Warehousing and distribution functions are characterized by relatively low ratios of employment relative to building coverage. Property taxes generated tend to be less than for more intensively utilized land, because of the lower capital investment requirements. For these reasons, there is resistance today in some communities to building more warehouses. Locations seeking to expand their 
employment base recognize that manufacturing pays higher wages and employs more workers. Other communities feel that commercial and office areas have more aesthetic appeal and have less truck traffic. What is needed is a wider understanding that industrial parks, properly located and specifically planned for a mix of uses, can have a pleasant appearance with minimum traffic and other ill effects upon the community.

Advantages

The major economic advantage of settling on an industrial park results from the fact that the organizer of the park is able to provide improved facilities and services more economically and quickly than can the small industrialist. Usually, the developing agency can improve land economically and install utilities, layout, and factory buildings cheaply because it is experienced in these matters and because costs are distributed among many units. The speed with which an industrialist can get started in production is usually an important factor. 5

The small industrialist saves the cost of conducting a survey to find a suitable site for his factory. He avoids the problems of finding a suitable parcel of land, and of collecting all relevant information on land assessment and tax rates, on the availability of basic cost, and on the many other considerations involved in selecting the most suitable site for locating a factory. Where assembling of land is necessary, he avoids the haggling and the possible bidding up of prices in acquiring land from several property owners. In certain situations he may benefit from being able to negotiate for a site confidentially with a park developer without revealing his intentions to his competitors.

In negotiating with the government, the individual industrialist is generally in a weak bargaining position. Negotiations may be time-consuming, difficult, and recurrent. Sometimes they may be the cause of embarrassment and strained relations, which can be future handicaps to the industrialist. Private 
developers of industrial parks can benefit tenants substantially by negotiating agreements with government agencies concerned with the property. Once the arrangements are made they may well apply to all occupants in the future. De facto industrial zoning is developed by this process and the relevant agreements are often written into the individual protective covenants governing, all tenants of the estate.

The industrialist may benefit from tax agreements reached between the developer and the municipality concerning the level of tax assessments. Naturally, the industrialist is benefited in making production plans if the future tax bill is known with some certainty. Conceivably, more equitable and favorable tax rates may be anticipated if the local government is negotiating with respect to the conditions that are to apply to an entire industrial tract. Contrastingly, when negotiating tax rates with industrialists individually, the administration has little notion about the extent of the future demand for industrial land in the community. Therefore, there is an opportunity to obtain more favorable tax treatment if the fark is dealt with as a whole. Moreover, the desirability of providing tax incentives for the occupants of an industrial park is more apparent to a local government if it can see benefits derived by the community from greater revenues and well-paid industrial employment. 6

Occupants of a park can also benefit when the basic utilities have been installed at the time of or shortly after settling on the property. Economies can be achieved by providing utilities, access roads, and streets for a sufficiently large area as a unit. Concentration of industrial users in a park enables a utility company to predict more accurately requirements of power, water, and waste disposal capacity. This is in contrast to making piecemeal arrangements with individual industrialists without having adequate information as to the size and location of future demand for utility requirements. 
Less obvious, but nevertheless important, is the benefit to the industrial tenant from the protection provided by the management of the park in controlling the actions of other tenants. The protective covenants with tenants usually define the uses that are permitted and the nuisances prohibited. Tenants are thus protected from detrimental activity by incompatible neighbors. The management of the park also may control the type of architecture (where buildings are not provided), and the landscaping about the factories.

Industrial parks provide the industrialist with the opportunity of acquiring a good location and modern factory accommodations. Parks may be located in the suburbs of cities, in nearby small towns and villages, and in areas distant from the large cities in order to achieve decentralization away from congested surroundings. With more space available, it is possible to provide larger loading docks and parking space, as well as easier access to less congested roads or to railroad sidings. A well-planned industrial park should provide sufficient land to permit industrialists to expand factory space in the future. Plants of different sizes will meet the different growth rates of enterprises. Lack of space should never be a handicap to the growth of enterprises.

Industrial parks provide distinct advantages to the urban centers and to the regions where they are situated. As a form of controlled industrial development, they are of particular interest to local governments concerned with guiding the growth of their communities, and to state governments wishing to promote the industrialization of a region.

Municipal governments may be under pressure to increase their tax base to continue or expand community services and projects. They may desire to increase employment opportunities. These are the usual motives prompting cities to support or promote industrial districts. The initiative in developing parks 
may be taken by the municipal government or by private real estate developers. Actual development may be done by private developers who assume all the responsibility or who may get varying degrees of community support. Development may also be carried out fointly between municipal and private interests. In some instances, municipalities promote parks themselves, but usually only as improved industrial tracts without buildings. ${ }^{7}$ By making investment in industry easier through the device of industrial parks, communities can exercise some control over the industrialization of their areas.

Strict selection of industry settling in an area is feasible through industrial parks. The control exercised over development can be more effective than that possible through zoning regulations. Industrial applicants may be selected who are likely to succeed and who will tend to promote industrial diversification and economic stability. Firms may be chosen whose competitive position is improved by the location in question. Restrictive covenants provide an additional method of controlling other aspects of industrial life not feasible in an industrial zone per se, especially for the purpose of enhancing the economic and social desirability and the beauty of the area.

Decentralization of industry may be in the interests of an urban area as well as the country at large. In a city it may be desirable to prevent or to reduce congestion. Efforts may be directed toward relocating industry from the central core of the city and toward establishing new enterprises in carefully planned industrial zones and districts. Even with efficient urban administration, zoning is not fully effective as a control device, and encroachment of other uses of land may be permitted in areas zoned industrial. In the absence of zoning, or even relatively good enforcement of zoning restrictions, the scattered industrial investment that inevitably results drives up the cost of installing streets, roads, utilities, and other services, not to mention the possibility of causing nuisances and other activities detrimental to the public. 
Where land use zoning is insufficiently practiced, it may be easier to obtain all the benefits of zoning by using industrial parks. These benefits include economy of development, a fairly dense concentration of enterprises, and the chance of exercising direction over the location of industry. Decentralized location will reduce traffic congestion in the central city. While plants in the park may be fairly well concentrated, good planning may prevent future congestion, especially by an improved layout of streets, by off-street parking, and by providing spacious loading dock areas. By suitable control over architectural design, property setbacks, kinds of materials utilized in construction, and proper landscaping, an environment can be developed in which it is pleasant to work and live.

Just as importantly, an industrial park may become the nucleus for further industrial and commercial growth. New enterprises may be induced to settle near the park because of the mutual advantage of providing goods and services for each other, or because of benefits deriving from the existence of labor skills and the general technological stimulation generated by industry in the park. One early effect is likely to be the clustering near the park of enterprises providing industrial services, including equipment repairing, wholesaling, and storage. Some of these services may be the result of initiative by the park sponsor. Restaurants and inns, retail stores, and shops providing personal services also may be expected to grow up at an early stage. The need for constructing housing and schools nearby will depend on how close the park is to existing residential areas and how adequate the existing transportation services are. Transport facilities for carrying workers and goods may need to be improved and expanded to meet the demands of the park. This kind of commercial and industrial growth can be advantageous to a community in expanding employment and incomes. 


\section{Limitations}

In spite of the many clear advantages of industrial parks, some limitations should be recognized. Most of the apparent disadvantages can be overcome by proper planning.

One concern with industrial parks is that their use can restrict investment in industry to only the most promising enterprises - those selected for location in the industrial park: thereby depriving center-cities of investment capital as well as the potential for attracting high growth industries. However, parks might be used to encourage the formation of industrial nuclei in strategic places, to stimulate high priority industries, and to modernize industry. In short, industrial parks can be used as a device for spearheading industrialization.

An industrial park, to be successful, should provide optimum locational advantages to the firms which it serves. It cannot serve its purpose or pay for itself unless its occupants are well located. Firms must have some advantage from the standpoint of location with respect to raw materials and markets, availability of labor supply, tax benefits, or other advantages in order to be competitively viable. There is further danger in mislocating the industrial park and creating the necessity of large investments in worker housing and other social overhead facilities such as schools, hospitals, places of worship, restaurants, and hotels. When location errors are made there is sometimes no provision for investing, in such facilities, and then the question may arise whether additional residential housing should be constructed or the park allowed to incur the risk of failure. 8

Economies achieved in the construction of industrial park facilities is a major selling point for the parks. On the other hand, there are some inherent dangers in these opportunities, and there should be some words of caution. There is the constant danger of overinvesting in facilities beyond the essentials 
which would prove sufficient to tenants of the park. Poor planning of industrial parks could result in planned industrial slums, with traffic problems, industrial nuisances, and inadequate buildings and utilities. 9

Even with good planning, it may take several years to complete the development of a park, to install the utilities and improvements, to select the tenants, and to dispose of the property. Hence, the importance of careful physical and financial planning and execution should be appreciated. One danger is that faulty execution will leave the park in a partially unfinished state for a long time, resulting in an uneconomic investment and handicaps to resident industrialists.

The big problem with perimeter or highway locations for industrial parks is their potential for detracting from the center-city. An industrial park may actually take business away from the center by drawing existing businesses away or by agglomerating all new growth in the park area. Industrial park planners must be very aware of the need to tie-in their planning efforts with center-city development efforts. A community which gets greedy and allows "unplanned" perimeter growth may see short-term gains which, in the long-run, result in the eventual depreciation of residential land values near the park, and the deterioration of the center-city business district.

An industrial park can make a great contribution to improving the general planning of a community in an area where there is no framework of comprehensive planning and where decisions regarding land use are haphazard and not wholly consistent. However an industrial park cannot be a complete solution to the planning problem. Without sufficient care, an industrial park might become completely surrounded by uncontrolled growth of business enterprises, which could turn a well-conceived project into a congested industrial slum and a large traffic culde-sac. While industrial parks provide many benefits to the developer, the community, and the industrial occupant, these benefits are gained only after 
long-range planning, extensive development expenditures, and the passage of considerable time. 
DEVELOPING THE INDUSTRIAL PARK

\section{A. Preliminary Evaluations of Community and Industry}

The possession of available land and a desire to industrialize is not enough for a community in today's competitive atmosphere. If it is going to be successful in competing for industry, the community will first have to consider and develop some basic information about itself. Industrial leaders are fully aware of the important effects that their location decisions can have in determining community growth and prosperity, therefore they carefully weigh the advantages and disadvantages of several communities before making a final decision on any one area. Community attitude, desire, and the ability to get things done are extremely important factors that are carefully examined by industry. Many similar characteristics can be found in every community. However, their degree of importance and their effectiveness within particular localities may vary considerably. Therefore, the primary objective in creating a good first impression is to develop a profile which will reflect these attributes in a someWhat general manner, but at the same time be sufficiently detailed so that the assets, attitudes, and accomplishments of the community are clearly visible.

The development of an up to date community study or profile is the first step in the promotion process. Selecting the appropriate study for a specific town will depend upon the availability of funds, the amount of time available to carry out the project, and the capabilities of those responsible for collecting and interpreting the data. Regional and state planning agencies are often very experienced at providing assistance in these projects.

It is possible to develop a useful profile without the cost and technological requirements which an indepth economic base study would necessitate. More practical, and economical, is a economic-social type survey. ${ }^{10}$ This is more 
in-depth than the typical community inventory, but not as elaborate as the economic base study. For most communities, it will provide a sufficient amount of useful data. It should first provide a basic profile of the community by covering in a somewhat general manner a description of location, climate, and soil topography - together with a brief history of the area. The profile should then divide into three basic areas: the people of the comunity, the economy, and the quality of life in the community.

In looking at the people of the community the profile should not only include the typical demographic data but should strive to shed additional light on the local population. In order to present a complete picture the following subjects should be explored:ll

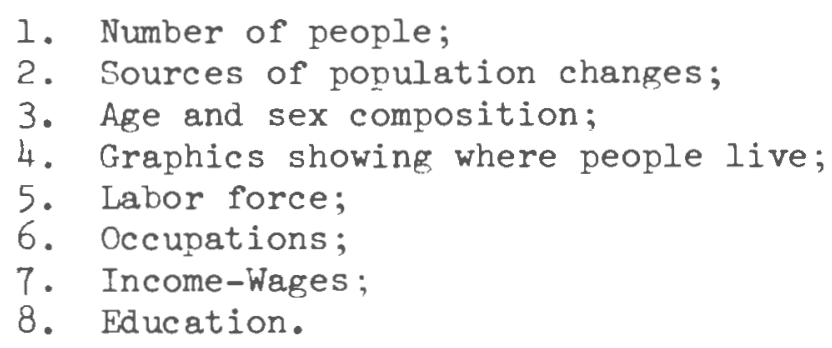

8. Education.

In looking at the community's economy, regional as well as local factors should be evaluated since they will have a direct affect on any community. The following subjects should be included in the analysis: ${ }^{12}$

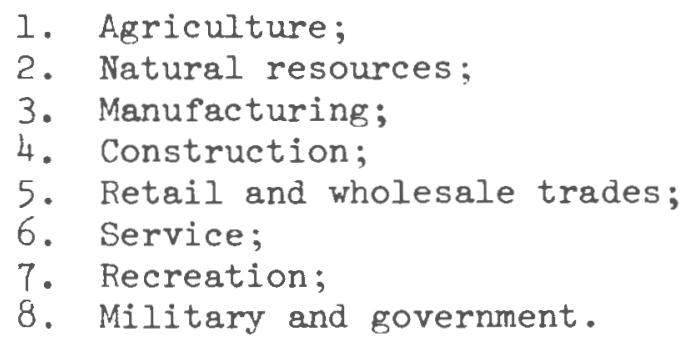


employer looks for a well-rounded employee, he also looks for a well-balanced community. The receptiveness of the community to industrial growth is an important factor in that industrialists would (obviously) rather settle where they are wanted. Each of the subjects listed below are important to potential residents and should not only be described in the profile, but should also be monitored closely by local governments in an attempt to maintain or build a wellbalanced community: ${ }^{13}$

1. Housing and neighborhoods;

2. Central business districts and other commercial areas;

3. School systems;

4. Recreation;

5. Hospital and medical services;

6. Transportation, utilities and public works;

7. Churches;

8. Safety;

9. Insurance classification.

\section{B. Location Theory}

All industrial promotion efforts culminate in the final selection of a community by the prospective industry. Yet, the process by which management decides among candidate locations is still probably the least understood aspect of area development. A survey of the literature shows that the stress is placed on the tangible factors which obviously must be taken into account: ${ }^{4}$ distribution to markets; freight charges on raw materials; comparative wage rates; degree of unionization; utility rate schedules; state and local taxes; and the like. But the typical location decision ultimately involves a choice among almost equally qualified sites - where distribution and operating costs may be very similar. Therefore, the final decision rests squarely upon management's review of the intangible considerations: qualities of the community and its ability to meet corporate objectives.

Community considerations appear to be more important for corporate office 
location than for manufacturing location. ${ }^{15}$ Because they wish to exercise their personal location preference, corporate officers often keep the responsibility for corporate location to themselves. The impact of personal preferences on industrial location is perhaps one of the most underrated and least understood aspects of the industrial development process. 16

When a site for a production facility is being chosen, personnel considerations are of paramount concern. There must be an ample labor pool from which to draw workers with the required skills. These workers must also be available at a price commensurate with their level of productivity and with wages in other areas. The case of administrative office location is more complicated since two kinds of personnel are employed - each presenting distinct recruitment problems. One of the assumptions of industrial development programs has been that economic growth may be accelerated through appropriate policies designed to make an area more attractive to industry and to people. Government policies may need to be designed to attract new industry to the area, to provide incentives for expansion of industry already in the area and to induce localized entrepreneurial efforts, all of which will create employment opportunities. 17 However, these policies may be worthless if they do not include strategies for preparing local residents to take advantage of the anticipated industrial growth. These same policies must be structured so as to not only retain the area's population, but to also attract migrants to the area, particularly migrants who possess skills not locally available.

of particular interest to governments who wish to attract industry to an area are firms most likely to be engaged in "high technology". These kinds of firms are considered less tied-down to specific areas when expanding or developing, environmentally desirable and high wage and high skill employers: they utilize local university talent, local consultants, produce high value-added low-weight 
products, are growth firms and require minimal additional economic infrastructure investment. ${ }^{18}$ Thus, these firms are seen as having all the desirable and no undesirable attributes. Further, it may be that these firms can be attracted to an area because of its amenities or quality of life. Thus government could invest in better schools, universities, recreation areas and activities, health, cultural activities and other similar areas, which would not only help attract high technology firms but which would also at the same time benefit the local population. In other words, an investment in social infrastructure for people rather than only economic infrastructure investment for firms. What must be remembered is that the community is the number one priority; first and foremost, the industry should serve to improve the community, and secondly, the community should provide benefits to industry.

These statements do little to assist the policy maker in efforts to induce faster development. What is needed is the translation of these general statements to specific action programs. Before that step can be taken, policy makers need to know what economic and quality of life factors are important to various types of firms within a location decision context.

For industries the best location is determined by identifying those factors considered most important to the company when determining the profit potential of the specific site. Below are five categories, the categories are not rigid, they only represent the areas where a company is most sensitive.

Market-Oriented Industries. 19 During the last thirty years, consumer goods manufacturers have grown quite rapidly. These companies, by developing and servicing their markets, have become highly market-oriented. At the same time, personal incomes have to a great extent become equalized throughout the country, a factor which in turn has developed new markets for consumer products. These companies closely follow their developing markets; as soon as a regional market 
appears economically feasible, companies will build plants to service that new market. This trend has led to the point where when one company establishes a plant in an area, its competitors tend to follow, even though the economic advantages may be slight. 20

Market-oriented industries are usually divided between consumable products and component parts. The manufacturers of consumables wish to be close to their markets, since their products are usually quite perishable. Reduction of high transportation costs is the reason most component manufacturers give for locating close to their markets. 21

Material and Resources-Oriented Industries. ${ }^{22}$ Industries select sites close to their source of raw materials in hopes of reducing their domestic transportation costs. Two basic types of industry fall into this classification. First are those plants consuming great amounts of fuel. The cost of transporting the finished product is usually much less than the cost of bringing fuel to the plant site. The second type of industry in this category usually handles raw materials that undergo significant weight losses during manufacturing. Some examples would be ore processing, cement manufacture, grain elevators, and food processors. Transportation-Oriented Industries.3 When considering transportation costs, industries that depend heavily on warehousing or bulk storage must consider more than just relative freight rates; they include other factors such as terminal costs, the cost of dealing with customers at distant points, the cost of maintaining large inventories at distant supply points, and the cost associated with the demand for fast delivery service. Fuel oil bulk plants are one example of industries which tend to locate near deep water ports. Manufacturers of highvalue instruments, on the other hand, might prefer to locate near air freight terminals.

Labor-Oriented Industries. ${ }^{24}$ There are many industries that rely 
heavily on highly skilled workers, and these industries normally tend to cluster around areas where these skills are plentiful. Perhaps the most desirable industries, from a community standpoint, are those in the research and development fields. These industries are viewed as "clean" industries, but they are the most labor-oriented of all. They employ a high percentage of scientists, engineers and other highly trained professionals. Therefore, they require a large pool of professional people, and they also desire to locate close to universities and research organizations. 25 Their general location patterns tend to be in or near centers of higher learning and the attractive suburbs of some of the larger cities. Non-Oriented Industries. Industries in this classification normally do not rely very heavily on any of the technical factors previously mentioned. They usually employ a small number of skilled workers and deal with technical products. Convincing such industries to locate in a particular area requires the services of an individual who is quite knowledgeable about what this type of enterprise needs. Since they are normally among the fastest growing industries, non-oriented industries offer great potential for outside industrial development.

On an elementary level, the concept of urban and regional uneven development implies that capital accumulation and the location of rapidly growing industries are not dispersed evenly throughout the nation. Instead, these activities agglomerate in a few cities and metropolitan areas, creating the phenomenon of prosperous and depressed regions. Being in at the ground level of any new enterprise has its distinct advantages. Since the growth process is cumulative and self-reinforcing, those activities that have gained a head start may soon outstrip their rivals in terms of economic growth and employment.

The present distribution of manufacturing employment in the United States continues to reflect the trenendous advantages that have made the Northeast one of the great manufacturing regions of the world. However, an examination 
of long-term trends reveals that the dominance of this region is on the wane. ${ }^{26}$ In order to put this decline into its proper perspective the manufacturing employment changes should be compared with population changes. Several trends are readily apparent when the data is analyzed in this manner. The relative decline of manufacturing employment in New England and the Middle Atlantic states has been considerably greater than the relative decline in their population, a reflection of the fact that the oldest manufacturing, regions of the nation have advanced to a higher level of economic development in which their economic bases are more diversified and greater emphasis is placed on tertiary employment. 27 This analysis reveals that there has been a movement toward equalization of manufacturing employment and population within every region of the country, which demonstrates that manufacturing employment is becoming increasingly market-oriented. Since substantial markets now exist throughout the country, regional dominance may disappear in the future.

Other factors also affect processing costs, but their influence promotes industrial dispersion, not agglomeration. Among the factors that counteract the agglomeration tendencies are such items as labor costs, the local tax burden and government subsidies.

Labor Costs. The development of cheap transportation facilities released many manufacturing processes from their former ties to large cities. Businessmen discovered that by shifting certain segments of the manufacturing process to low-wage areas while maintaining other functions in the central city, they could have the best of both worlds. 28

Labor cost variations basically result from two factors. First, some areas have a lower cost of living. In these areas, workers can achieve the same standard of living even though they are paid less than workers residing in high cost of living, regions. Second, regional variations in labor militancy, productivity, and labor laws create real wage differentials. 29 Whatever their cause, wage disparities do influence the location of industry. 
Industries searching for a cheap labor site will locate in the region with the lowest cost of living, even if real wages are equal. This is particularly true if the industry employs a substantial number of unskilled and semiskilled workers and sells on the national market. ${ }^{30}$ Under these conditions, businessmen can maximize profits by reducing their outlay for the various factors of production; the site with lowest cost of living will also be the site where dollar outlays can be minimized.

Tax Burden. The widely held belief that tax differences among states and localities are an important factor in industrial location decisions has had a major influence on taxation and economic development policies for decades. Businessmen have argued that high business taxes have induced industry to locate in lower tax jurisdictions. They claim that the economic decline and loss of jobs will halt only when these cities cut their taxes and improve their business climate.

Despite its prevalence and persistence, the belief is not supported by the considerable study devoted to assessing its validity. 31 Research on the effect of state and local taxes on location decisions reveals that although tax differences may play a role in certain decisions and may sometimes be influential in the final stages of the decision process when the choice has been narrowed to a few locations that meet more basic criteria, their effect is not a significant factor in most industrial location decisions. Clearly, an industry will not relocate simply to reduce its tax burden, unless the tax savings offset the cost of new construction.

This is not to say that taxes have no effect - differential tax rates can have a serious impact on the Northeast. Since construction cost must be incurred wherever industry decides to build or relocate, the relative tax burdens will be sufficient, in some cases, to tip the decision against continuing at the 
old site. In this manner, the highly taxed Northeast is placed at a competitive disadvantage with respect to the sumbelt. In this way high tax burdens may deter new firms locating in this region, while prompting the exodus of expanding businesses.

Subsidies. Historically, government subsidies have taken three forms

other than tax credits, abatements, and forgiveness: ${ }^{32}$ (1) loan guarantees; (2) low interest loans; and (3) Industrial Development Bonds. These devices will be discussed later in examining financing of industrial park development. The devices have been condemned by city and state officials for forcing communities to compete by offering subsidies to industry. 33 They argue that when one community or region uses these devices, all others must also offer subsidies if they wish to remain competitive. Firms will locate somewhere with or without incentives - no new firms will exist solely because of these subsidies.

\section{Management}

Management of industrial development consists of a combination of public relations, administration of standards, and delicate coordination of development activities. If an industrial project is subject to failure, there are generally two internal areas responsible for the nonprofitability. They are: (1) the financing of the development, and (2) the management of the park. A good project can deteriorate rapidly because of mismanagement.

Long-term management of the industrial park should be planned right from the beginning, and the necessary organizational arrangements should be written into the project proposal. The necessity to provide continuing management and supervision over the industrial park, during the development and selling phases and after the park has been sold out, sets it anart from single-site industrial development. The basic objective of management during any of these phases is to insure an adenuate, stable cash flow to the developer. 
Because the industrial park is a long-term investment and commitment for the developer, it is necessary to maintain its attractiveness throughout the development phase. Lack of attention to industrial park appearance can undermine the success of later stages. If the developer is leasing space in the park on a long-term basis, he wants to protect his investment over the long run. For the private developer looking for future business, his reputation is in a large way dependent on the reputation of his existing parks.

To promote harmony in the administration of an industrial park, it may be advantageous to establish a committee of tenants to which some responsibility may be delegated on matters affecting the common interests of the occupants. 34 Committee responsibility may include self-policing relating to nuisance activities and the regulation of traffic. Limited self-policing may be preferable to direct control by the park management. Such committees may be useful for direct negotiation with industrialists.

The organization which develops an industrial park is often responsible for the assembly and financing of the land, the preparation of a development plan, site preparation, the preparation of development standards, the provision of utilities, the sale and leasing of land, the promotion of the district, and its continuing operation and maintenance.

Private corporations have developed industrial parks for one reason to make a profit on the sale or leasing of land and buildings. Most of the public corporations which have developed industrial districts were formed by "civic minded leaders".35 The main interest of such groups in developing an industrial district is to improve the economic stability of their communities.

Public corporations have two main advantages for these civic minded leaders to use for the development of a district. First, public corporations can qualify as non-profit organizations in the eyes of the Internal Revenue Service. 
This means that their entire earnings, if any, can be reinvested in the development of the district. The second advantage is that public corporations can solicit and receive funds for development costs from business leaders and other sources of capital.

Management of industrial development is a specialized field. The traditional management of commercial and apartment buildings deals with the operational and maintenance aspects of building improvements. In the industrial development field management must also be concerned with selling and leasing, and maintaining good public relations in the community. The profect manager becomes the industrial promoter and public relations man for the project both as the development takes form and after it has become part of the community. Maintaining a harmonious relationship between the project and the community is one of the key responsibilities of the project manager.

Management of large-scale, long-term industrial developments generally follows a three-phased program which features different priorities and goals for each phase. 36 During the initial project implementation phase, coordination and timing goals are created to establish the park's character and reputation and to initiate the sale of land to seed tenants. The second phase covers the maturing stages of development and is primarily concerned with sales pace and price levels. In the last phase of development, management assures that the properties are being operated and maintained properly.

In the first phase of management coordination of the infrastructure development and attracting seed tenants is of paramount concern. But also important is the relationship between management and the community. The scale of the overall development and its impact will influence the nature of the community's reaction to the development. Concern for environmental factors may bring lots of attention to potential industrial development. To the degree that the developer has incorporated measures designed to insure the implementation and 
maintenance of a high quality industrial environment, this problem can be mitigated. The success of the "good neighbor" image of the development may hinge on the diplomacy with which these problems are resolved. Failure to respond quickly to community concerns can result in time consuming, costly delays for the developer and for the community. This is very important, because a timely completion of infrastructure is not only vital to the seed tenants but also to the overall success of the project. A project's best salesmen are its tenants and owners if the initial investors are not satisfied, it may be difficult to gain their support for future promotional efforts.

Coordination and timing are also necessary for management during the maturing phase, but with a different emphasis. Emphasis in this phase is placed on tenant selection, enforcement of project standards, financial management, and maintenance of the development's reputation.

If a detailed market analysis has been conducted, it will have suggested the optimal tenant mix for the industrial park. The actual occupancy pattern should fall in line with the projected occupancy pattern. To avoid a disfointed, scattered image, it is important that management keep the long-term goals and objectives firmly in mind and not sacrifice them for any potentially detrimental short-term considerations, a very real temptation in many cases. Assuring the continuation of an industrial development's marketability is of obvious importance. The establishment and enforcement of restrictive covenants concerning architecture, setback requirements, outdoor storage, loading, and parking requirements can serve to assure marketability. The concept of positive encouragement, backed by controls and continuing supervision, must be handled on an equal and impartial basis. A well-nurtured understanding among tenants of the value of complying with the covenants will be far more effective than waiting to enforce noncompliance. Whereas, the initial objective for the 
management's staff was timing, coordination, and acquisition of a seed tenant for the project, the basic objective of management at this stage is to maximize the long-term financial potential inherent in the development.

Once an industrial park is sold out there are different ways of handling. management. One way is through a tenants association which would operate much like a homeowners association. Under this format, the occupants play an integral role in the maintenance of the park and in enforcement of the standards ascribed to by the ownership groun. Another way of handling long-term management is to leave it in the hands of the community. What often happens is that once the development is sold out, the developer departs leaving the enforcement of standards to the municipality's zoning department.37 This situation can also occur when a voluntary association is created which relies primarily on social pressure and lacks a legal mandate to maintain the development. With a mandatory association the responsibility for enforcement should rest with the tenants, allowing them to enforce covenant requirements which might not be legally enforceable by the public.

While the creation and nurturing of an effective association of tenants places another burden on the industrial developer's management team, the longterm protection of the initial development objectives yields benefits to the tenants, to the community as a whole, and to the developer's reputation. The return, and the protection it provides, makes the effort of proper management worthwhile.

\section{Preproject Planning}

Industrial park development is a systematic process that involves careful planning and control. These are two of the basic distinctions of the planned district from the single-site development. Timing is another important distinction. 
Timing is critical to the initiation of the development, the subdividing of the land, the installation of site improvements, and the sale or lease of the sites and buildings.

The principle steps in the development of an industrial park include: 38

1. Preliminary or background analysis;

2. Site selection and acquisition;

3. Preparation of a development plan;

4. Formulation of use restrictions and controls;

5. Preparation of a district layout;

6. Installation of site improvements;

7. Building construction;

8. Management; and

9. Marketing.

Careful planning of each step in the development of an industrial park is of vital importance, whether sponsorship originates in a governmental or private agency. It must be recognized that a great deal is at stake - the financial success of the project and that of its industrial occupants; the safety of investments; and the preventing of waste of economic resources. Moreover, an industrial park can have a profound effect on the community where it is placed. To justify the investment the park should have the effect of making a net contribution to the economy of the area, and should seek to prevent urban congestion and the development of an industrial slum.39 To achieve these objectives requires sound planning. The planning process for industrial parks and employment centers should be continuous. Improvements in transportation, shifts in tenant mix, technological changes in processing or communication, changes in the lifestyle of employees, and other factors may modify the layout, the structures, and the optimum mix of uses - even in the final stages of marketing. An ongoing planning process is important to insure completion of a balanced and viable project which can be expected to have a long and productive life. However, the concentrated planning effort comes during the initial stages of development.

The eventual location of an industrial park can have tremendous local 
and regional impacts. A single industrial park can directly affect several thousand families, and indirectly many thousands more. The location of an industrial park not only affects the length of time and mode of transportation required for the trip to work, but also effects the types of industry that can be attracted, as well as the community's capital budget program. 40

As is the case in large-scale residential development, it is often found that in developing an industrial park, phased development may be more desirable than developing the project all at once. 4 If any slowness is anticipated in attracting industries and if the budget is limited, it may be better to develop a portion of the park at a time, as the demand for space seems to warrant it. Such an approach also has the positive benefit of reducing the capital carrying costs for the developer.

A comprehensive, workable project proposal for the development of an industrial park is extremely useful to preproject planning in that this proposal can demonstrate that the project is feasible and also provides a document which can aid in obtaining private capital or governmental sanction and budget appropriations. The proposal should include information on many important features. An estimate of what the park will cost, including fixed and operating costs is essential to any proposal, as is information on the financing of the project. The proposal should also include a description of the proposed site with a tentative layout plan which would account for the kinds of facilities and services being proposed. The proposal should show the long-term development plan including the proposed organizational structure of the sponsoring and managing agency, and the proposed methods for marketing and controlling the park. Finally the proposal must, quite obviously, show the features of the plan which make it beneficial and acceptable to the community.

Planners of industrial parks should also ascertain whether a master 
nlan for the community exists, and whether their plans can be fitted into it. $A$ comprehensive community master plan is an outline for long-term development against which current requirements are evaluated. 42 The master plan should contain all features conducive to the long-term improvement of the area, including provision for transnortation, for distribution of goods and services, as well as for health and welfare. Projections of nopulation growth should be the backdron against which effective planning for community services is done. At a minimum, there should be a tentative zoning of areas showing the distribution of residential areas, business and commercial areas, industrial areas, railways and bus stations, streets and highways, places of worship, and schools and hospitals.

It may also be helpful for planners of industrial parks to negotiate longterm agreements with the municipality in order to relieve future occupants of the park of uncertainties concerning taxation, utility rates, protective services, and the provision of utilities, roads and streets, and other facilities. To have the area zoned industrial is a basic requirement. This means that residential developments and other nonconforming uses will not be permitted in the area in which industrial activity is to be conducted.

Industrial development can also be used as a vehicle for urban redevelopment. Where redevelopment of the central city with light industry is not feasible, industrial parks located on the outskirts of metropolitan areas can provide a means of relieving population oressure in the central city and in encouraging some degree of population decentralization. If handled properly, a planned decentralization program can be executed in a way to keep down the additional investments required for new roads, streets, utilities, and housing. But there is also a danger in this connection. Construction of an industrial park in a new area may necessitate complementary investments to an extent that the economic wisdom of the entire profect may become questionable. Such additional investments should be 
taken into account in the preliminary calculations, and the whole cost should be evaluated against alternative development projects.

A well-planned location and development can enhance a community's appearance. Local employment, tax revenues and sales can be increased while air and water quality, and the natural environment are protected if the industrial park is properly located, designed, and serviced in accordance with a comprehensive community development plan.

\section{1) Site Selection}

The selection of a site will be approached differently depending on the viewpoint of the sponsoring agency. Government agencies may make their selections based on economic characteristics or development needs of different areas (targeting), while private sponsors may be more concerned with market areas and labor availability .

Regardless of who sponsors the project, the steps in locating an industrial park are the selection of: (1) the region, (2) the community, and (3) the tract itself. In making a selection of the general area, the choice will depend on the comparative economic advantages a refion or community can offer to the kinds of industries it is planned to develop in the park. For government agencies, often times the aim will be to expand and strengthen the industries of an underdeveloped region. The final step in the location problem is to select the specific site for the park in the community. A municipality which takes the initiative for developing an industrial park will, obviously, be concerned only with selecting the site from a number of alternative tracts within the municipality.

Sponsoring agencies need to be aware of the necessity of taking into account the location of raw materials and markets, convenient access to road and railway transportation, and favorable shipping rates. These help to determine the competitive position of industries strongly oriented to sources of raw materials or to markets. 43 The locational requirements of proposed industries must be 
considered especially carefully when the government is following a deliberate policy of decentralizing small-scale industry. While a policy of industrial decentralization has many desirable aspects, the general pursuit of this objective, while ignoring the locational demands of industry, can lead to the danger of establishing a competitively weak industrial sector. 44

The choice of a regional location and of the most suitable industrial site in the region is a complex problem. In view of the impact of industrialization on a community, it is worthwhile to undertake a careful survey of and appraisal of alternative tracts. Location has a profound affect on the viability of the industrial park and its tenant industries, as well as the economic position of the chosen community. Therefore, spending money on planning and research which can provide detailed data and analysis regarding site location can provide important returns.

Two major factors should be kept in mind when choosing the region for an industrial park. One is the potential impact of the new industrial complex on the development of the region. In the case of industrial parks developed by a governmental agency, it is especially important to take into account the probable impact of such industrial investments on employment and regional standards of living. The other location factor is the extent to which the industrial park may facilitate improvement in the competitive position of new or existing industry. 45

One of the most important decisions in developing an industrial park involves acquisition of land. After the general area has been chosen, the problem is to select the most suitable tract. For comparative purposes, it probably makes sense to obtain information on a number of tracts. At an early stage, a check should be made to determine whether the plots comprising the potential tract can be assembled into a satisfactory unit. The choice of tract should be based upon an evaluation of a number of factors which are elaborated upon the following pages. 
In making a tentative selection of tracts for consideration the park planners should evaluate the difficulties and costs entailed in assembling plots, held by different owners, into tracts of suitable size and characteristics. 46 Assembling land is relatively simple for a public agency which has the authority to condemn land, but it may be an acute problem for private buyers. Dealing, with many individuals may force up the price of land, since it is seldom possible to carry on negotiations in secrecy. After the availability of parcels has been checked industrialists often take up options on one or more to ensure that they will be available at a later date if desired. No matter what the source of sponsorship, assemblinp, of land will be done most conveniently and economically if the tract can be put together with as few parcels as possible. 47

Tracts should be evaluated and compared for a number of characteristics. To the industrialists the most important factors have to do with reducing the cost of developing the park and of ensuring: (1) economies in future onerations for the industrial occupants, and (2) the convenience of their employees. 48 The general principles of land selection and assembly that apply to single-site developments are equally appropriate for the larger industrial nark. In general, the developer should purchase land that already has as many attributes as possible that industry wants. This helps minimize the elements of site conversion and development. To the community the important factors are much different, but no less important. They deal with protecting abutting properties, minimizing congestion, minimizing costs to the municipality, and protecting the environment. In both respects the following features should be considered when analyzing a prospective site: (1) industrial zoning, (2) size of the tract, (3) topography and environmental considerations, (4) access to utilities, and (5) access to transportation. Zoning. If the municipality has a planning commission and zoning ordinance, all vacant land areas under consideration should be checked as to whether 
or not they are industrially zoned, and, if so, the ordinance should be reviewed to determine the permitted uses in each type of industrial zone. If the municipality is without planning or zoning, or areas are being considered outside the municipal limits and are not subject to zoning, then special attention should be given to neighboring properties to assure that they and industry will be compatible neighbors.

While current ordinances tend to protect industrial land from other uses, the designation of such areas is not necessarily based upon modern industrial land use requirements or impacts. 49 Many zoning ordinances limit the types of industry allowed through specific lists of permitted uses, usually followed by a specific list of prohibited uses. These lists are generally based on lists from older ordinances whose derivation is obscure.

In an effort to eliminate the rigidity and shortcomings of permitted use lists, many communities have incorporated industrial performance standards in their zoning ordinances. Designed to classify industries by their environmental impact, performance standards deal with the process, not the products, by translating, the effects of the production process into quantifiable terms. 50 The primary advantage to this technique is that it allows the zoning ordinance to keep nace with current advances in industrial technology while at the same time maintain the quality of the local environment. The implementation of industrial performance standards, however, requires competent staff and sonhisticated equipment to insure compliance. Furthermore, communities should recognize that sole reliance upon industrial performance standards can result in the siting of any type of industry that can satisfy the criteria. Moreover, some industrial clients may be skeptical of performance standards since actual compliance may only be known after production has commenced.

Another alternative to traditional zoning anproach is "imoact zoninE,". 
This technique incorporates performance standards and a specific evaluation method which is applicable to all zoning uses rather than just industrial. The formula for measuring capacity against demand is fixed but the numbers are subject to change as special circumstances warrant. 51 The fundamental concept behind impact zoning is that approval of a project depends upon proof that the project will generate nositive or neutral impacts on the community. A number of different approaches to land use regulation are included under the heading of impact zoning. One of the most common requirements of impact zoning ordinances is the preparation of an environmental impact assessment, but more advanced codes demand analysis of the socio-economic and physical impact of the project. 52

"Overlay districts" represent another alternative to traditional industrial zoning. This technique requires special consideration of site specific factors by establishing additional requirements for the primary zoning district. These factors are normally associated with natural limitations such as steep slopes, high water tables, or unique natural areas. The granting of a building permit within an overlay district requires conformance to the primary district's use restrictions as well as any special conditions related to the limitations noted on the overlay.

The "Planned Unit Development" represents another alternative to traditional industrial zoning. There is no hard and fast definition of a planned unit development (PUD), however most applications of this technique share similar characteristics. A PUD is generally incorporated as a provision to the zoning ordinance in an effort to provide some degree of flexibility in the zoning standards. 53 It will often provide for a variety of uses on a specified tract of land under strict performance standards. In addition, higher use densities are allowed through clustering in exchange for more open space in the form of parks, plazas, etc. PUDs have generally been used in mixed residential developments, however, 
the inclusion of industrial and commercial uses within the PUD concept is also nossible.

Size of Tract. A basic consideration in planning an industrial park is to make it large enough to achieve economies of scale in the provision of utilities, building facilities, and services. On the other hand, the park should not be so large as to result in traffic congestion and other diseconomies attributable to size. 54 For the nark as a whole, a basic decision is required on the ratio of the plant size to the size of the lot. 55 The primary aim should be to prevent overcrowding and the development of an industrial slum property by carefully anticipating the uses for which provision has to be made. Provisions should be made which allow for items such as: (1) landscaping of lots, (2) loading space for trucks and general vehicle parking, and (3) land required for further expansion.

A 1972 National Association of Industrial Parks survey and a 1960-1961 Urban Land Institute study indicates that the average size of industrial parks is about 312 acres. ${ }^{56}$ Ultimately, the size of the development must be based on market demand which will allow reasonable absorption over a logical development period based on the needs of the community; the constraints of available sites; the costs of acquiring, holding. and developing larger projects; and, the need to accommodate new regulations.

Topography and Environmental Considerations. Physical characteristics are important to developers for several reasons. The topographic, hydrologic and soil features of a site can substantially affect the techniques and materials renuired for construction. These in turn will directly influence the cost of a project, possibly making it uneconomic. The physical environment also has great importance. Varied slopes, trees, and natural ground cover provide a diversity and visual attractiveness that are much desired by potential customers. In addition, certain natural conditions such as wetlands and underground water supplies can 
carry with them legal issues which can have profound effects on development feasibility .

Project feasibility evaluation begins early in the development process with a preliminary engineering study of the site. Any problems which may be too costly to remedy can be uncovered before a major financial commitment is made to proceed. Such preliminary work is usually done on a limited budget and, therefore, cannot be expected to determine and evaluate all problems. However, major problems should be evaluated during this phase of the work. Ideally, the preliminary work is completed before the site is actually acquired.

The topographic survey is basic to site evaluation. Some knowledge of the topography of the vacant land tract is necessary for estimating the grading necessary for a building site or otherwise evaluating the land's industrial potential. Survey data should be displayed on a map form which shows the ground surface contours of the site. Contours of perimeter property should also be shown, particularly if they relate to watershed areas. ${ }^{57}$ This base map is used for terrain analysis studies which indicate such characteristics as ground slope and drainage patterns which can provide clues to the presence of sinkholes, fault lines in earthquake prone areas, and susceptibility to flooding. ${ }^{58}$ Existing physical features such as springs, creeks, and the perimeter of wooded areas, should also be located in the topographic survey. It may also be wise to single out large trees suitable for retention. The location of existing man-made features such as roads, railways, utility lines, and buildings should also be determined.

Subsurface conditions must also be determined in order to accurately estimate the capacity of the underlying materials to support buildings, as well as the possibilities for drainage and grading. Preliminary evaluation of the soils and foundation conditions at the proposed site should be made at the earliest practicable time by a soils or geological engineer. Early analysis can often 
determine potentially troublesome conditions such as soils of low bearing capacity, swelling or shrinking soils which can affect floor slabs and pavements, and high groundwater levels requiring special drainage systems. 59 Many of these problems can be determined by the preliminary soils and foundation evaluation. A preliminary study of soil characteristics will determine suitability for industrial development. Most important will be identification of site areas where soil characteristics render the land economically unsuitable for building or other surface or subsurface improvements.

Several federal laws, designed to protect the environment, will have a significant effect on future and current industrial park projects. The National Enviornmental Policy Act (NEPA) of 1969, the Clean Air Act of 1970, the Federal Water Pollution Control Act Amendments of 1972, the Wetlands Protection Act of 1977, the National Flood Insurance Act of 1968, and the Noise Control Act of 1972 , all have potentially far-reaching effects on industrial land development. 60 Under NEPA, proposals for many projects using federal funds must be accompanied by an environmental impact statement (EIS). The purpose of the EIS is to document the effect of a proposed land use change before the change is made. The Clean Air Act of 1970 requires information on anticipated traffic flow and vehicular usage from "indirect sources". The Federal Water Pollution Control Act Amendments requires industry to obtain a permit for discharge of any pollutant into navigable and certain non-navigable waters of the United States. The conservation and protection of wetlands is dictated by the Wetlands Protection Act. In addition to complying with national environmental legislation, developers should be aware of local performance standards which may already affect the prospective site. These standards can have significant impacts on the land use arrangements and may limit the suitability of certain portions of a site for certain types of industrial development. 
Access to Utilities. To qualify for further consideration as industrial sites, the tentatively selected land tracts should either have access to suitable utility service or provisions for installation of those utilities. A site relatively close to existing utility lines - water, electricity, gas, sewage disposal will keep down costs of extending, the lines and may help to ensure economical service. It is necessary not only to determine that water, power, natural gas lines, and sewer lines are at or near the selected areas, but also to determine the capacities of the lines. Because of the hiph cost of installation, if sewer lines do not exist in the vicinity of the selected site, the industrial value of the site may depreciate. The available nower and gas line capacities are not as important at this stace of investigation as is the determination of the availability of service or, at least, the feasibility of extending such service to the sites under consideration. As utility line data are obtained, they also should be plotted on the base man.

Access to Transportation. The most important location consideration for an industrial park is the array of transportation services available at the site. 61 Transportation is a vital part of our marketing system. Tying together production, processing, and distribution, it serves as a critical link between the producer and consumers of goods and services. The major difference between planned industrial districts prior to World War II and the modern industrial parks has been the new freedom in choice of locations made possible by improved roads, expanded auto ownershin, and an expanding trucking industry. 62

Because industry generates considerable traffic, it requires a major thoroughfare, not only for convenience of access but also because the type of traffic generated often includes heavy vehicles. Heavy volume combined with vehicular weight requires streets, roads, and bridges built to withstand extra heavy wear. Such surface standards are found primarily on major thoroughfares because these facilities are intended for heavy traffic service. 
In addition to the convenience of access there are several other transportation considerations which are of importance to both industry and the community. First, a plant site snould be located so as to provide ease of access for customers and workers traveling to and from the plant from various sections of the area. Secondly, these movements should be possible without forcing heavy or bulky vehicles to travel through the central part of town and various residential areas. This need for nuisance-free access is also important where employee traffic is concerned. Employee traffic will probably involve the largest number of vehicles traveling to and from the site. Nuisance-free access can protect against disruptive traffic flow in other parts of the community.

The tendency of industrial parks to cluster near hichway interchanges has been documented by a 1970 Port of New York-New Jersey Authority survey. 63 The move towards highway locations for individual industrial plants and for planned industrial parks has also increased land requirements because of the large parking lots needed for emnloyees and visitors, and because of off-street truck facilities required to accomodate inbound and outbound shipments and vehicular storage areas.

Highway locations provide three major advantages to industry. First, the speed of transport brings economies in transport costs and savings in canital investment. Secondly, the labor market area serving, a plant is vastly expanded. Finally, the location serves to expand the market area. A plant or warehouse near the highway can serve the central city, the suburbs, and other nearby metronolitan areas. Trucks can also serve a wider overnight delivery area. If a location near a railway facility is possible, this may be an added advantage. Although certain industries do not reauire railroad freight service, the industrial nrogram of any community served by a railroad should consider sites affording access to railroad transportation. For many industrial operations, 
direct rail shipping is economically essential, and therefore a community that has substantial acreages of industrially suitable land along a railway may have a competitive advantage in attracting industry.

Industrial park planners should also consider the service available for transporting workers to the factories. It may be necessary to determine whether existing bus franchises provide transportation to the industrial park site, and if so, whether sufficient buses are available to transport workers at the beginning and end of working shifts. Where facilities do not presently exist, it may be necessary to negotiate with the carriers to extend or expand the service.

2) Selecting Industries

A great deal of time and effort can be saved if industrial park planners can determine the basic type of industry best suited for their area. 64 Two kinds of investigation may be useful in selecting candidate industries - area development surveys, and industry outlook surveys. 65 The aim of the area development survey would be to produce an inventory of the industrial resources and markets of a region, and after considering its various advantages and drawbacks, including location and available skills, to evaluate its competitive position and investment opportunities. The result is a list of industries appropriate for the region. The industry-outlook surveys are designed to determine the technical and economic problems of specific industries, existing or projected, and to evaluate their growth potential. Both types of study assist in selecting industries that represent the most promising candidates for investment, and they can also help to determine how these industries may be assisted.

\section{3) Layout and Facilities}

At an early stage a decision has to be made concerning the manner in which the industrial park will be laid out and the kind of facilities and services it will provide. 
This paper has emphasized the importance of integrating the planning of the park with the long-range plans of the community. It has stressed the need to come to definite agreement on the respective responsibilities of the municipality and the developer for providing the required utilities. Similarly, there should be adequate provision for linking the industrial park into the road system of the community in order to facilitate communication and transport within the region and to other regions. The street system within the park should be planned in accordance with basic principles of economy in development, ease of communication, and avoidance of congestion.

In designing the layout, as much information as possible should be obtained about the needs of potential tenants. At this stage the sponsor may have no definite knowledge of the specific clients who are going to settle on the property, but it should be possible to anticipate their main requirements. Sometimes a park will be planned for a selected group of industries, such as light engineering industries, or for a specific group of diversified industries. Study of the needs of such industries is necessary so that the proper facilities can be constructed and the right kind of services provided. Where there is more latitude in the selection of industries, a prior study can determine the kinds of industries that would obtain the most benefit from location in an industrial park, as well as those industries that would be most beneficial to the community. Such a study might have an effect on the size of the park, since the degree of interest in it could be tested.

The layout plan for the industrial park is developed in terms of the obfectives of the developer, the physical and other construction considerations involved, and the use controls and restrictions decided upon by the developer and his advisor.

One major determination to be made by the developer is the physical 
planning or layout of the lots. This should be based on the requirements of industrial firms likely to be attracted to the park. Maximum flexibility in design will allow for custom plotting for industrial customers and provide room for subsequent expansion. The real solution to the expansion problem, of course, is to convince industrial purchasers or tenants to acquire plenty of land at the outset for expansion. Failing this, however, a high degree of flexibility in street layout and plot planning can be most helpfur.

Land absorption in most industrial park developments is slow and erratic. Predicting specific space requirements of industrial users can be extremely difficult. For this reason, development in phases is an important planning and development tool. To the extent that local planning and zoning authorities allow ambiquity in subdivision plans filed, time and money may be saved because numerous revisions are avoided. Phased development is also valuable since considerable sums are usually expended before any revenues are received by the park developer. Therefore, phasing the development process can be a major factor in the success of the entire undertaking. It conserves on cash, and requires less total commitment on the part of the sponsor at any one time and this, in turn, reduces the developer's risk.

The layout nlan of the industrial nark is essentially the physical portion of the develonment plan. It indicates the location of the major frcilities that are to be provided by the developer, and sets the ceneral shape pattern of the block of sites. When it is designed to be executed in a phased manner these stages must be carefully integrated with one another so that continuity in development is provided. The layout plan of the industrial park should provide for as much adjustment and adontion to the topography of the land as possible to take full advantage of drainage and flows.

The following checklist includes many of the important factors involved in planning the layout: 66 
1. The plans for streets, tracks, and utility easements should aim to minimize development costs and obtain maximum efficiency of operation.

2. The layout plans should seek to minimize the length of tracks, length of utility lines, quantity of earth moved, and the area in streets, but with provision that street widths be adequate for moving the anticipated traffic flow efficiently through the park.

3. The street pattern should be such that block lengths and lot depths are adequate but not excessive in keeping with the needs of prospective tenants.

4. The drainage runs should coincide with major streets.

5. Acute angles should be avoided at important intersections.

6. Streets and tracks should be laid out on contours so that parked trucks and freight cars can stand on level ground.

7. The layout should permit free flow of truck traffic without interference from rail freight switching.

8. Rail curvatures should be kept at a minimum. Rail lead tracks should be sited so as to cross a minimum number of streets and reach a maximum number of sites.

9. Layout plans should show building set-back lines in accordance with approved restrictions or existing zoning ordinances.

10. The layout should keep to a minimum the number of odd-shaped lots which can be difficult to sell or lease.

11. The tract layout should permit prospective tenants a choice of size, shape, and type of site to meet their specific requirements.

12. The layout should permit development and construction in progressive stages, keeping in mind future needs and expansion but recognizing that the immediate demand for sites may not fill the industrial park.

13. A certain amount of zoning may be desirable in order to provide some segregation of different types of industries, especially where nuisances and hazards may be involved.

4) Restrictions and Controls

To safeguard industrial tenants, and keep an industrial park attractive, sponsors often use supplemental methods for controlling future land use within the park. Protective controls may be embodied in covenants, leases, and purchase contracts, or they may be incorporated into sales agreements. Such restrictive controls supplement municipal regulations. 
Covenants provide the industrial developer with private land use controls in the form of a legal instrument to protect future occupants of his development, its investors, and the community interests. Covenants can apply to virtually every aspect of industrial development including site coverage, architectural design, parking requirements, signs, and landscaping. Restrictive covenants usually relate to the feneral use of the land, to the nature of specific improvements and their location, and to undeveloped property. Any snace standard which the sponsor thinks is not properly covered in the zoning code may be included: such as setbacks, side yards, off-street parking, off-street truck loading, percent of site covered by structures, and height of buildings. Covenants can decrease intensity of land use, but cannot increase site coverage beyond that provided in the zoning, ordinance.

The kinds of controls and protective covenants recommended are not merely prohibitions and limitations of land and building use. Workable industrial park controls emphasize function and performance standards. They are specifically geared to the needs and requirements of the kind of industry that the developer is seeking, to attract to the nark.

Performance standards establish the type of limitations on use and occupancy that are employed. Whatever form the controls take, they must be binding on all occupants of the park for the same long-term period. While flexibility in planning and design of the district is an important virtue for development purposes, flexibility in the application of restrictive covenants is not. Some citizens groups prefer the upgrading of industrial land standards, through amendment of existing zoning codes, to privately enforced controls. Because of the private nature of covenants, a strong enforcement section is necessary in the covenants. The establishment of controls is one of the most critical aspects of park planning. Controls set the park's character for the future. Minimum standards and controls tend to insure compatability among occupants of the district, 
as well as between the park and the community. The final set of covenants should reflect and be responsive to reasonable concerns of adjacent land owners, occuDants, and citizens organizations.

\section{5) Factors Affecting Development Costs}

The financial feasibility of an industrial park is dependent in large degree on the ability to buy land at a low price and to hold it for a number of years before receiving a return on the investment. The sponsor will have to weigh the question of how much land to buy. It may be desirable to execute a phased development program. In this case more land should probably be purchased than can be immediately developed with the current appropriation. The reason is partly to obtain lower land prices, but even more to assure that adequate land is available for comnleting the project. On the other hand, there may be negative effects on the community if land is held out of productive use for long periods of time. The fine line between obtaining enough land for expansion and protection against misuse of potentially productive (socially or economically) property, is a difficult one to draw.

Caution should be exercised in selecting the land for the site. There is always the danger that very low-priced land may be too far from good transnortation facilities, raw materials, and markets, and that this may jeopardize the success of the project. On the other hand, it is important for private developers to buy land cheaply so that they can keen their taxes low, and compensate for the income lost while holding the land. Because of the high cost of holding land, good location and aggressive development are essential for getting the property into effective industrial use as nuickly as possible.

The cost of improving raw land varies considerably with the general to-

nography of the tract. 67 This determines the amount of work required for clearing, gradinf, and drainage. The denth of the lot and the type of development, such as 
is represented by the design of the street system, are the other major determining factors. The shorter the depth of the lot the higher development costs may run, since more improvements are required per acre.

The type of material used and the width of the streets largely determine the cost of street construction. The length of the street system, which is dependent on the size and shape of the blocks, is the other major cost determinant. The cost of installing utilities include the cost of extending sewge, gas, water and power lines, and storm drains. Costs of installation will vary in accordance with labor and material costs. The cost of installing basic utilities may be lessened under certain conditions by seeking the cooperation of the municipality. The municinality may take responsibility for the streets or it may share the original cost of streets and of connecting sewers and water mains to the industrial park. Naturally, the costs of constructing buildings, if provided, will vary greatly from place to place, depending, upon differential costs of labor and materials. Perhaps more important is the design of the buildings planned and the materials used in construction.

Breakdown of development costs also should be made for each phase of the development. 68 This is necessary in order to properly evaluate cash flow needs which affect the costs of financing the project. The cost per acre for developing the first phase of a project may be substantially higher than the average cost per acre for the entire project. This frequently occurs because of the need to construct complete storm and sanitary sewerage and outlet facilities, which will ultimately serve the total project, during the first phase.

Actual costs will not be known until the development work is completed. However, forecasting costs as accurately as possible is vital to the developer. The Urban Land Institute lists the following items which are normally included in the development cost estimate: 69 


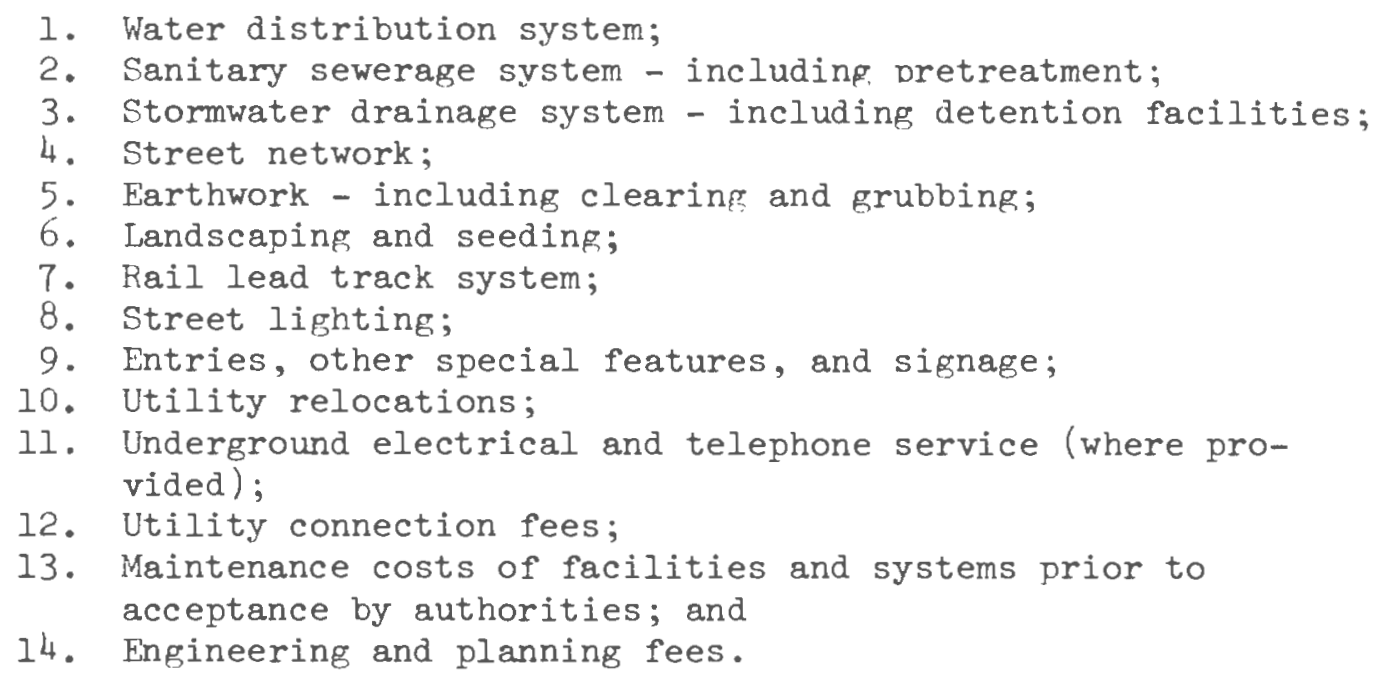

\section{6) Selling vs. Leasing}

Both selling and leasing are effective marketing devices used in successful industrial park developments. With either option the firm has the use of its plant over a long period of time. In many instances industrial park developers utilize both techniques. ${ }^{70}$ The advantage to the developer of a policy which includes both sales and leasing is that it offers one more element of flexibility in the disposition program. By providing a choice for the industrial firm, the developer of the planned industrial district can add considerably to the potential effectiveness of his marketing program.

The decision to sell or lease depends on the types of facilities offered. If the sponsor develops building space in his park, in the form of a shell building or a customized structure, then leasing may be better received as an alternative. Traditionally most industrial park developers do not lease sites independently of buildings. 71

Ieasing on an indefinite basis provides the lowest financial barrier to entering businesses because it requires no large down payments. However, from the standpoint of the industrial park sponsor, there are some disadvantages to leasing. For example, since the industrialist has no equity invested in the property, a lease may make it cheap for him to move from the nark unless safeguards are 
provided to prevent this. One way of preventing this type of situation is to provide lease agreements which are written to run for a number of years before they provide for a break.

In view of these problems, it may be preferred to sell property so that the equity invested will encourage the industrialist to build his future on the future of the community where he is located.

A rise in the value of industrial properties resulting from community growth has implications for selling or leasing policy. Such long-term increases in property values usually result from increasing competition for land. During inflationary periods, the value of factory buildings, other facilities, and land will also rise. Selling the property transfers the right to future capital gains to the buver. It is true that some of the gains might be recaptured by property and capital gains taxes, but this is an advantage possessed by the municipality, not the sponsor. ${ }^{72}$

Leasing of industrial property would permit the management to raise future rents, insofar as the lease agreements permits, to the level of competitive rental on properties outside of the park. Such a policy is desirable in the interests of equity and of maintaining competitive relationships. Furthermore, the recovery of additional long-term revenue in excess of the original investment costs may be necessary to compensate for rising costs of providing additional factory space for expanding the park. Thus, by retaining ownership and leasing properties the management company participates in future increases in the value of the property, which provides a hedpe apainst inflation and higher replacement costs.

$\Lambda$ major argument in favor of selling industrial property is that it permits a rapid turnover of funds invested. The release of funds invested enables the management company to speed up the development of the park. This policy of 
selling may be a vital factor in facilitating the expansion program, especially of a private development company. It also may be significant for a public sponsor faced with an inadequate appropriation or with insufficient funds due to rising construction costs. In other words, a policy of selling properties to clients may require a smaller government investment in the industrial park program. Therefore, under such a policy, moneys anpropriated for industrial development go further. By selling properties, such a program can be executed by a government agency on a limited budget by use of a revolving investment fund.

\section{E. Financing}

Three basic financial approaches can be utilized to cover the development of a tract through actual development, either in combination or in separate stages. 73 These approaches are: investment group financing, institutional financing, and government programs. The basic incentive for investment groups is return on investment. Financial institutions view industrial develonment as leading to the creation and development of new customers and new business. This concept not only encompasses an individual industry, but more importantly, the employees who will become part of the community. The government programs - whether sponsored by local, state or federal governments - are usually predicated on the theory that if an industry locates in a particular area, it will add substantially to the economic level of the community or the entire region.

$$
\text { According to the Urban Land Institute there are four primary lending }
$$

sources for industrial development: ${ }^{74}$ life insurance companies, commercial banks and savings banks, real estate investment trusts (REITs), and a final category which includes many other sources of investment capital.

Insurance Companies. Insurance companies are not only one of the chief repositories of the nation's savjngs, but are one of the leading institutional sources of long-term mortgage financing. With the excention of REITs, insurance 
companies generally have broader lending powers than other lending sources.75 Because of this they operate with greater flexibility and their financial activities cover a wider range. Being less conservative and less restricted than banks, insurance companies may finance projects which are not attractive to - or which may not be nermissible for - banks, and savings and loan associations. Insurance companies may also take on an equity or ownership position as well as a mortgage. Joint venture financing, whereby they provide the debt financing, receive a return on their investment, and participate in the profits of the development, is also of interest to insurance companies.

Commercial Banks. Commercial banks represent the most important source of short-term or interim financing in the industrial real estate field.76 Although commercial banks in some areas tend to avoid long-term industrial mortgages, or make them available only as an accommodation to important depositors, they will still be active in the construction phase of industrial financing. The basic reason for this reluctance is economic. They do not want to tie up large portions of their real estate portfolios with one loan for long periods of time.

Commercial banks are business corporations operated by and for the stockholders. Except for small numbers of banks located in the nation's largest financial centers, commercial banks which provide funds for industrial development have a local focus. 77 Lending practices for commercial banks can be expected to vary widely since these banks adapt their practices to the competitive position they occupy in the market place.

Real Estate Investment Trusts (REITs). Real Estate Investment Trusts are another major source of funds for the industrialist. There are four specific types of REITs. ${ }^{78}$ The most common type of REIT, known as the short-term trust, focuses on construction and development loans much like the commercial banks do. They are closely tied to the short-term outlook of real estate and the real estate 
market as a whole. Long-term mortgage REITs finance permanent mortgages. The difference between long-term mortgage REITs and other sources of funds lies in the fact that they obtain funds by issuing securities and stocks rather than by inviting deposits. Equity REITs go one step further, in that they invest directly in the project as an ownership group. These investors are looking for a good return on their investment, along with the partially or totally tax-free income flow through long-term capital gains and the potential for sheltering income through the depreciation of property. Some REITs specialize in land purchase leasebacks. In this case, they purchase the ground under a completed property and enter into a long-term leaseback.

Other Lending Sources. Additional lending sources include individuals (partnerships or joint ventures); corporate, institutional, union, and government pension funds; public development companies (as a joint venture partner); mutual banks; saving and loan associations; and syndications.

Because of the nature of the case study which follows a more indepth examination of government financing methods is needed. Government loans have helped numerous small industrial firms get started, expand, grow, and prosper. The loans, provided by all levels of government, have been used by firms to construct, expand, or convert facilities; purchase or lease building and equipment; or obtain materials and working capital.

The federal government alone has nineteen separate agencies supervising over ninety different programs that can fund industrial development ventures. 79 For industrial park development the most important program is funded by the Economic Development Administration in the Department of Commerce.

Economic Development Administration loans and grants are made for upgrading economically depressed areas by providing financial assistance that will result in the creation of permanent jobs and higher incomes for the area's inhabitants. 80 The Public Works and Development Facilities Program is directly 
linked to industrial park development. This program can benefit industrial development activities by helping to reduce a firm's capital outlay and operating costs. The program provides direct and supplementary grants and loans to communities only for purposes such as the construction or up-grading of industrial parks, utilities, streets and access roads; water and sewage facilities, primarily serving industrial and commercial users; port facilities for industrial expansion; regional airports; skill centers for the training or retraining of employed and underemployed adults; certain tourist facilities and other facilities to stimulate economic development. ${ }^{81}$ The Economic Development Administration also provides technical assistance to the community to help plan its development program.

State and local governments also provide financial assistance to promote industrial development. There are four main types of state and local assistance programs. Two of these, state industrial finance authorities and local industrial bond financing, provide funds obtained from public sources. The other two, statewide development corporations and local development corporations, are quasi-public in nature and advance funds acquired primarily from private sources. While these programs are not designed strictly for industrial park development, they often work in conjunction with Economic Development Administration loans for industrial park development.

State Industrial Finance Authorities. State industrial finance authorities include two different types: one guarantees industrial loans made by private lenders, and the other makes direct loans of state funds to industrial firms. State loan guarantee authorities insure the repayment of mortgage loans made by private lenders. States pledge their credit as hacking for the loans and usually provide reserve funds to pay claims in case of default. Some state direct loan authorities restrict their loans to ventures that can be financed jointly with federal government agencies, while others limit loans to ventures located in labor 
surplus areas. Others, however, have no such restrictions. The loans are used to finance fixed assets, primarily land and nlant costs.

Local Industrial Bond Financing. Through the sale of industrial bonds local Eovernments finance the purchase of land and the construction of manufacturing plants for resale or lease to industries. The industry agrees to lease the oroperty, paying, all costs incidental to the use of the real estate, with the rental paid by the firm equal to an amount that will retire the bonds over the term of the lease - usually just sufficient to cover the debt's principal and interest and the maintenance of the pronerty.

Two types of industrial bonds are used; some states permit only general oblipation bonds, others authorize only revenue bonds, and still others allow both. General obligation bonds are secured by the taxation nower of the government issuing the bonds, while revenue bonds are secured by the industrial property acquired by the bond sale. Because of this, investors prefer general oblifation bonds over revenue bonds, which have no real guarantee of payment from the government that issues them. The premise of debt financing is that there is a reasonable exnectation of an adequate return on investment to cover the principal and interest.82 Statewide Development Corporation Loans. State business development or credit corporations are chartered by states to help finance high-risk ventures that exhibit promise of success. Although state chartered, the corporations are privately financed organizations formed by individuals and businesses interested in advancing the prosperity and economic welfare of their areas. Loans also are made to local development corporations. State development corporation loans are made to purchase land or to provide buildings and equipment. However, they also can be made to provide working capital to expand production and employment. Local Development Corporation Loans. Local development corporations may be called industrial development commissions, industrial development coroorations, industrial development foundations or community development corporations. 
Most have been established in the past two or three decades and are organized as nonprofit corporations. Others are profit cornorations, and still others are charitable trusts. A large number were either promoted or established by local chambers of commerce, and many today still operate directly under chamber of commerce supervision.

The local development corporation can be either a profit or a nonprofit organization. Initial capital is raised by the sale of capital stock, memberships, or debt securities to local residents and other individuals or to firms doing business in the community. Sometimes grant funds are made available to the local development corporations from state or federal agencies, EDA, FmHA, model cities or urban renewal programs. Other funds are borrowed from banks, insurance companies, federal government agencies, state development corporations, private lenders, and state finance authorities.

Funds raised by local development corporations are used for a variety of purposes, primarily to finance the construction of industrial plants for individual firms. 83 other funds are used to provide loans to industrial firms for the purchase of land, plants, and equipment, for plant construction and modernization, and for working capital.

Before seeking funds for industrial development, industrial park planners need to determine the total amount of financing required. Lenders will need not only this information, but also a good deal more knowledge about the profect before they can evaluate loan requests. Once the total amount of costs is determined, it is important for the park planners to prepare financial forecasts to determine the amount of financing required and also the type of financing that would best fit the future cash flow of the park. For example, because of the difference in interest rates, it would not be advisable to finance on a long-term basis if the cash flow indicated that the park developer had the ability to repay shorter-term 
loans. Financing on a short-term basis would be inappropriate if the forecast indicated that it would nlace a strain on the capability of the park to repay. Lenders expect management to demonstrate a basic understanding of their projections and how they were developed and to be able to explain and substantiate the validity of the major premises upon which the projects are based. Projections are so basic to the planning of a project that some leaders mav view a working, knowledge in this area as an indication of the ability of management to operate the proposed park successfully. It is important that they include realistic provision for all start-up and operating costs until the park reaches the break-even point.

\section{F. Marketing Techniques}

Warketing of an industrial park should start as early in the development

process as is nossible. 84 Acquisition of seed tenants and advertising of the project is usually begun with informal contacts by the sponsor and major national companies or prestigious regional and local firms. Attracting high quality companies at the outset can be instrumental in determining the long-term success of the park.

The marketing program or strategy must be coordinated with the conclusions drawn in the detailed market analysis and with the goals and objectives of the sponsor and the community. Once the community and sponsor have pinpointed the type of industries they wish to attract, they must attempt to discover which companies are planning new or expanded facilities.

Ascertaining a list of these comnanies is possible, but requires the aid of outside sources. Among the best sources for develoning, a nrospect list are the local public utilities. ${ }^{85}$ Utilities develop a substantial amount of information in resnonse to industrial inquiries, and therefore, they are in a position to provide the names of those industries that have expressed interests. Another source 
a community can approach is its own state Industrial or Economic Development Department. Because of the fierce competition for expanding industry among the various states, these agencies are often extremely helpful in providing contacts. State and local Chamber of Commerces are also important sources of information regarding prospective businesses, as are planning commissions, redevelopment agencies, and other public or quasi-public entities.

The most inexpensive method of marketing the property is to deal with brokers in the community. ${ }^{86}$ If this approach is used, regular sales meetings should be held with brokerage firms to inform them of new developments in the project, such as changes in the plan, pricing modifications, and current sales or leases which have been made.

There are several other popular marketing techniques. Spot advertising can be placed in trade journals or professional publications associated with industry. Brochures sent directly to prospects and cooperation with brokers provide the best avenues for marketing the property. 87 Naturally, for the marketing strategy to be most effective, the thrust of the program must be directed toward the potential clients identified in the market analysis. Signs on the project site, particularly if highway visibility is good, also can convey the quality of the development and serve as an effective marketing tool.

Regardless of what marketing strategies are employed, there are two documents which should be a part of the marketing program: (I) the technical services package, and (2) the sales brochure. 88

The technical service package consists of statistical data and descriptive materials of interest to prospective tenants and includes information relating to population, labor, financing, taxes, utilities, and transportation services. A summary of the protective covenants, development constraints, building setbacks, landscaping requirements, and building exterior qualities should be provided. These 
regulations should be set forth in a positive way rather than as negative controls. The potential tenants need to be convinced that these covenants were created for their benefit - rather than as a way to prevent abuse.

The sales brochure describes the sponsor and its development experience, sets forth the theme or concept for the development, and identifies the seed tenants. A map of the site, showing specific sites, interior road networks, utility lines, and rail access should also be included. Similarly, a location map showing the relationship of the site to the total community and the general road and rail networks which provide access to the property, should also be included. A.lso included in the sales brochure is a synopsis of community characteristics, which can be drawn from the market analysis studies.

Industry sources have recommended that the total cost of the marketing program should be somewhere between three and five percent of the total projected revenues of the industrial park. ${ }^{89}$ The development expertise of the sponsor and the nature of the competition will help to determine the actual allocation. Marketing flexibility during the course of development is also critical. In the event that a given strategy is proving ineffective, the developer must be prepared to modify his approach.

Those involved in industrial development must define their market with the greatest care. The sponsor must try to gain the attention of that very limited number of companies that might use the park, and the community, most effectively. Various marketing techniques can be used, with varying degrees of effectiveness. Some of these techniques are described and evaluated below:

Space Advertising. Advertising in national or regional magazines or newspapers is the most frequently used method of attracting industrial prospects to a community. 90 The cost of this type of advertising can be quite high depending on the type of publications used. 
f.dvertising, space in snecialized trade puklications with smaller, more select, circulations is usually far less exnensive than in his?-circulation newsnaners or magazines. Tor the community, taretire on a fer selected industries trade pullications can be used not only for advertisine iut also as a method of ronitorinf, activities of these target industries.

Putlicity. While advertising involves nurchased tire or snace, nuclicity is concerned with "free" time or space blaced as a result of such techniques as press releases, exclusive articles, interviev, or press conferences. The news release offers two advantages: ${ }^{9}$ (1) it is free, and (2) it is often more effective to have a third party (such as the media) speak favorably of a product or a community than for the company to act as its own spolsesman.

On the other hand, putlicity is also hiphly competitive. The key to raking the front pare or business column depends on qualjty, not quantity. 52 of course, local support for the program is essential in order to senerate food local news coverage which may attract more regional or national attention.

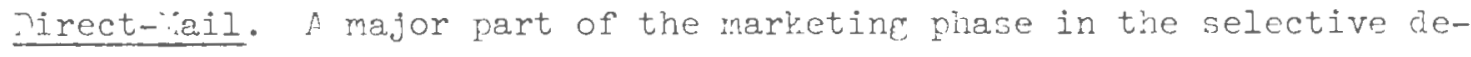
velonment anproach is the use of direct-mail. The direct-mail form of promotion is viewed as the most selective, since the development croun can pick its tareets and make an effort to attract only the selected industries. The direct-mail method provides total control by the sponsor, and the success of the campaign is easily measured by the rate of response.

The problem with the direct-mail approach is that every major site locator in the country is deluged with direct mail, and your message must be special to warrant further consideration. The letter must be well written, brief and concise, and include three essential ingredients: (1) the eve-catcher, (2) the facts, and (3) the offer of further information." 3

Brocinures. As mentioned earlier, brochures are essential to the marketing profram. The brochure has two purposes - to provide freneral information about 
the community and to arouse enough interest in the community to induce a specific request from the industrialist for more detailed information. Brochures should avoid concentrating too much on the visual effects of printing and photographs because the experienced businessman looks for pertinent information, not fancy packaging. Similarly it is important that up-to-date statistics be used, and that the promoter avoid filling the brochure with indiscriminate facts that make it so voluminous that it is unreadable.

Promotional Meetings. One way of attracting industrial prospects to a particular area is the so-called development trip, or a trip by the sponsor to the corporate offices of prospective industries. Obviously, development trips to large cities are costly. Another problem is getting the right people, at the top of the corporate ladder, to attend these meetings - rather than their powerless subordinates. Even if you do get the top people, it is usually difficult to avoid the dangers of oversell or undersell. The positive benefits of face-to-face meetings with corporate heads is obvious, but the above-mentioned problems also must be addressed.

Follow-up. Often overlooked, but perhaps the most important of all the promotion techniques is the direct sponsor-to-prospect contact which results from interest provoked by earlier promotional contact. Only communities with a unique set of extremely desirable characteristics can afford to simply wait for opportunities to host prospects who venture into the community. 94 In order to achieve real success in industrial develooment activities, most communities need to act, rather than react or respond; they must aggressively seek prospects to bring into the community. Follow-up requires good data, good timing, and most importantly, good staff. Sponsors or promoters, and community leaders, must carefully evaluate individua? situations and determine precisely what level of response and effort is warranted in each case. 
Patience is an important factor. Too many communities want quick dynamic results and are often unwilling to spend the necessary time to achieve their goal. Because of the complexities of the economy, as well as industry decisionmaking, it can sometimes take years to work out the necessary details before a decision about locating a new plant is made. Those communities willing to take the time and exnend the energy are more likely to succeed.

All marketing techniques can be used with some degree of success. Budget constraints necessitate the careful evaluation of the specific project, the tenants you are trying to attract to the project, and the effectiveness of the various marketing techniques. Overall the objective is to blend them together in a formula that yields the greatest results for the least expense. Appendix I may help to calculate the appropriate blend - it shows industry responses towards development information provided by industrial development agencies. 95 It suggests, as a general pattern, that industrialists find little value in unsolicited Industrial Develonment agencies information, and may be an indication of the secretive nature of the location-decision process. 


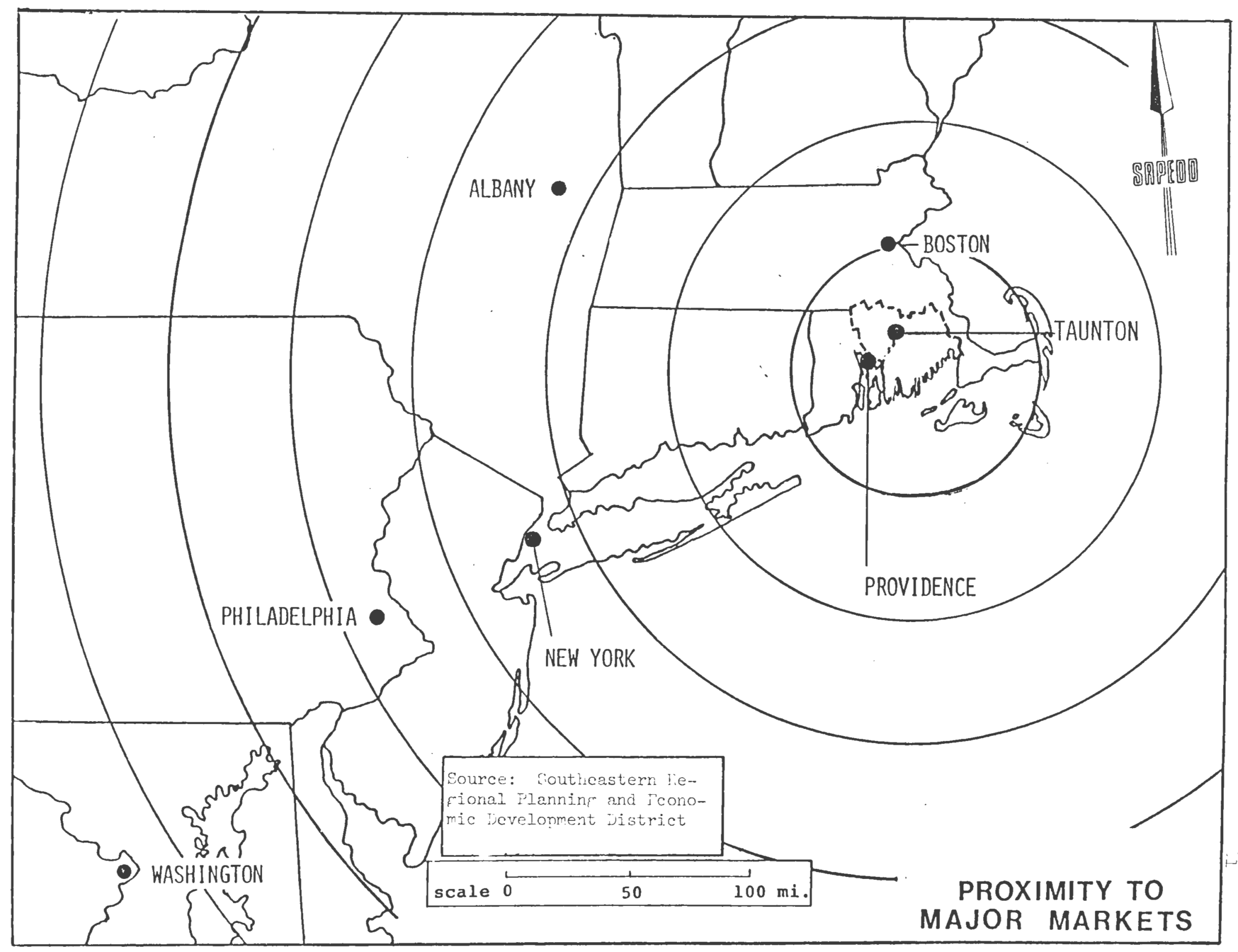




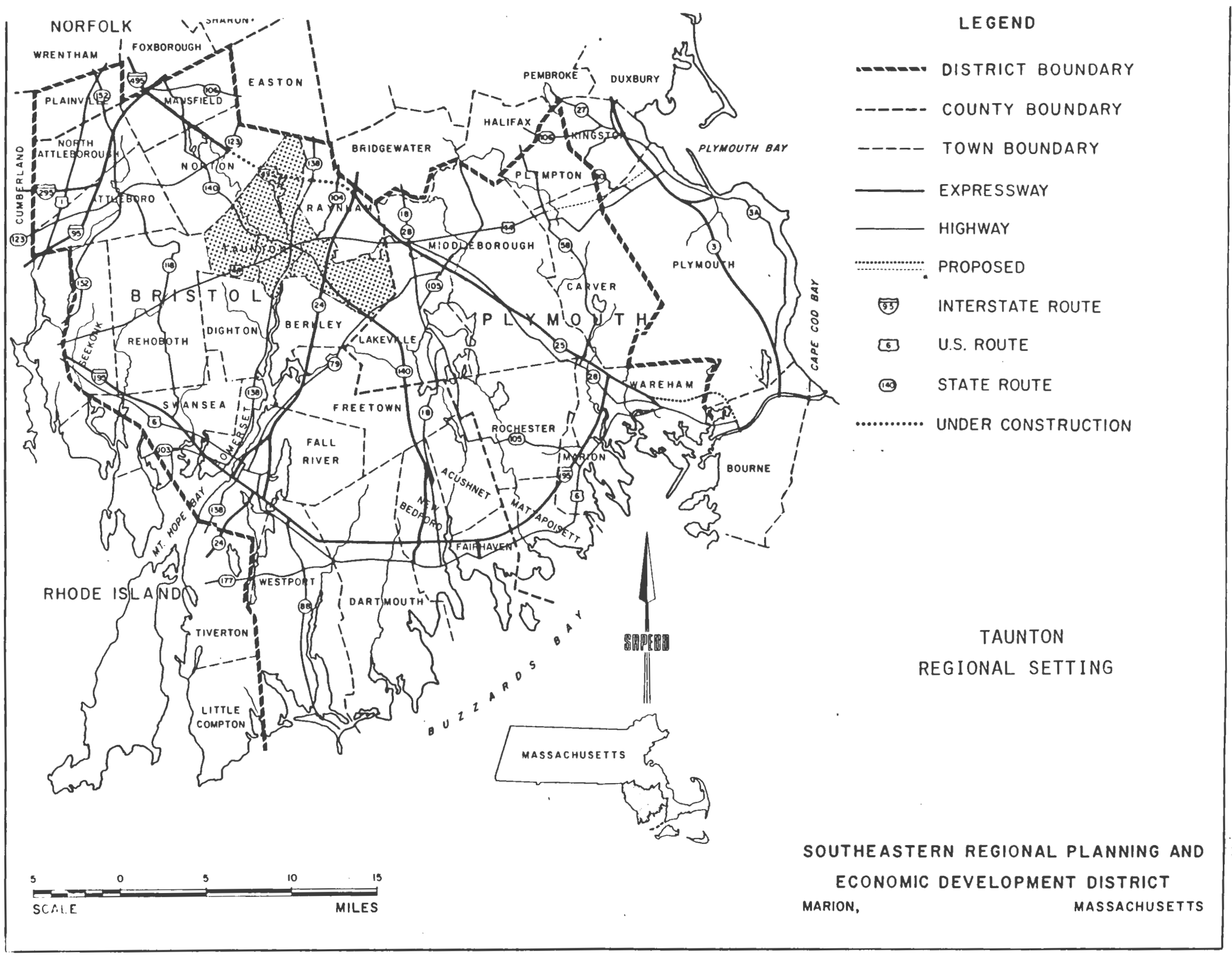


III

CASE STUDY - :YYLES STAITDISH INDUCMPIAL

PARY, MAUIMON, YASEACHUSETTS

\section{A. Maunton}

Taunton, the seat of Bristol County, is an industrial city located on the Taunton Piver in southeastern "assachusetts. Located apnroximately 32 miles south of Soston at the reographical center of southeastern lassachusetts, Mauntcn is strategically placed within twenty miles of five major urban areas: $n t-$ tleboro, Brockton, Fall Piver, Neh Bedford, and Providence, Thode Island. It is the largest city, in terms of land area, in ilassachusetts - with more than 49 square miles of land. 96

Whe city is governed by a 'ayor and :unicinal Council. Ixcent for the management and control of the public school syster, the "ayor and Council have jurisdiction over the peneral management of city affairs and over the functioning of all city denartments. Mhe "unicipal Council consists of nine members who, like the :ayor, are elected to a two-year term.

The community was founded $k y$ Elizabeth Pole, the only voman ever to found a city in this country. Pole moved from England to "assachusetts in 1633 and in I637 Eartered with the Tamnanoag Indians for a portion of their woodlands. Following, her lcad, a year later, forty-six men and women bought additional land from Yassasoit, the chief of the Vamnanoags. They purchased, for two shillings per acre, the plantation known by the Indians as Cohannet, "the land of quicli-running: water", consisting of sixty-four square miles. Fole was honored by tne authorities as beine the founder of the town and was given lands in the first purchase. These lands were laid out for her by Captain :yles ctandish, one of the original pilgrims. In 1640 the settlement was named Taunton in honor of Taunton, Insland. Fhe city 
seal bears the motto "Dux Femina Facti", meaning: "A woman was leader of that which was done". It was incorporated as a town in 1639 and as a city in 1864.97

Today the Taunton area is said to be the third most highly diversified industrial area in New England, ranking behind Worcester and Bridgeport, Connecticut. Some of Taunton's industries include: silverware, textiles, machinery and machinery parts, chemicals, dresses, sporting goods, rivets, jewelry, and bronze and copper ware.

Taunton has several industrial areas and three industrial parks: a private park with 65 acres bordering on route 140; Dighton Industries Co. Industrial Park with 350 acres on the Dighton-Taunton line; and the city's Myles Standish Industrial Park with 437 acres.

The Myles Standish Park will be the major industrial area affected by the completion of Interstate 495 in north Taunton. The park has the potential for creating 4,000 to 6,000 jobs. 98 overall development of the park, which has been funded with Economic Development Administration money, hinges on the completion of I-495. The construction of I -495 is expected to make the city more attractive for development.

Secondary effects of route 495-induced growth may include: (1) development pressures in environmentally-sensitive areas, aquifers, and farmlands; (2) increased demand for water and for other services; and (3) changes to community character and tax rate.

The major pressure for commercial development in the city is expected to occur on Bay Street. 99 Traffic volume is projected to increase from the 1975 total of 3,000 average daily trips to more than five times that in $1990 .{ }^{100}$ At present Bay Street is zoned for low density residence, and is still rural in character. The road passes through Watson Pond State Park, and Iake Sabbatia, and overlies a high yield aquifer that may be used for future water supply. 
The north Whittenton and Oakland areas may also feel the effects of new travel patterns and residential development pressures. Because land for development on Bay Street is limited by the parks, lakes and conservation land, continued growth can be expected along Field Street and parts of the Oakland area occupied by farms. While the abundance of appropriately zoned land in the area will limit demand for industrial land, farmland in the area may be very susceptible to commercial and residential development pressures. Until recently Taunton has tried to attract industry to the city on its own, without the cooperation of surrounding communities. This attitude is probebly attributable to the feeling in the community that Taunton's abundance of land places it in a favorable competitive nosition. But recently the groundwork has been laid for a more regional approach to economic development. Government officials and industry leaders from the entire southeast region have formed the Southeastern Massachusetts Economic Development Committee, which is trying to make industry aware of the region's potential. Their efforts are described later in this paper. 


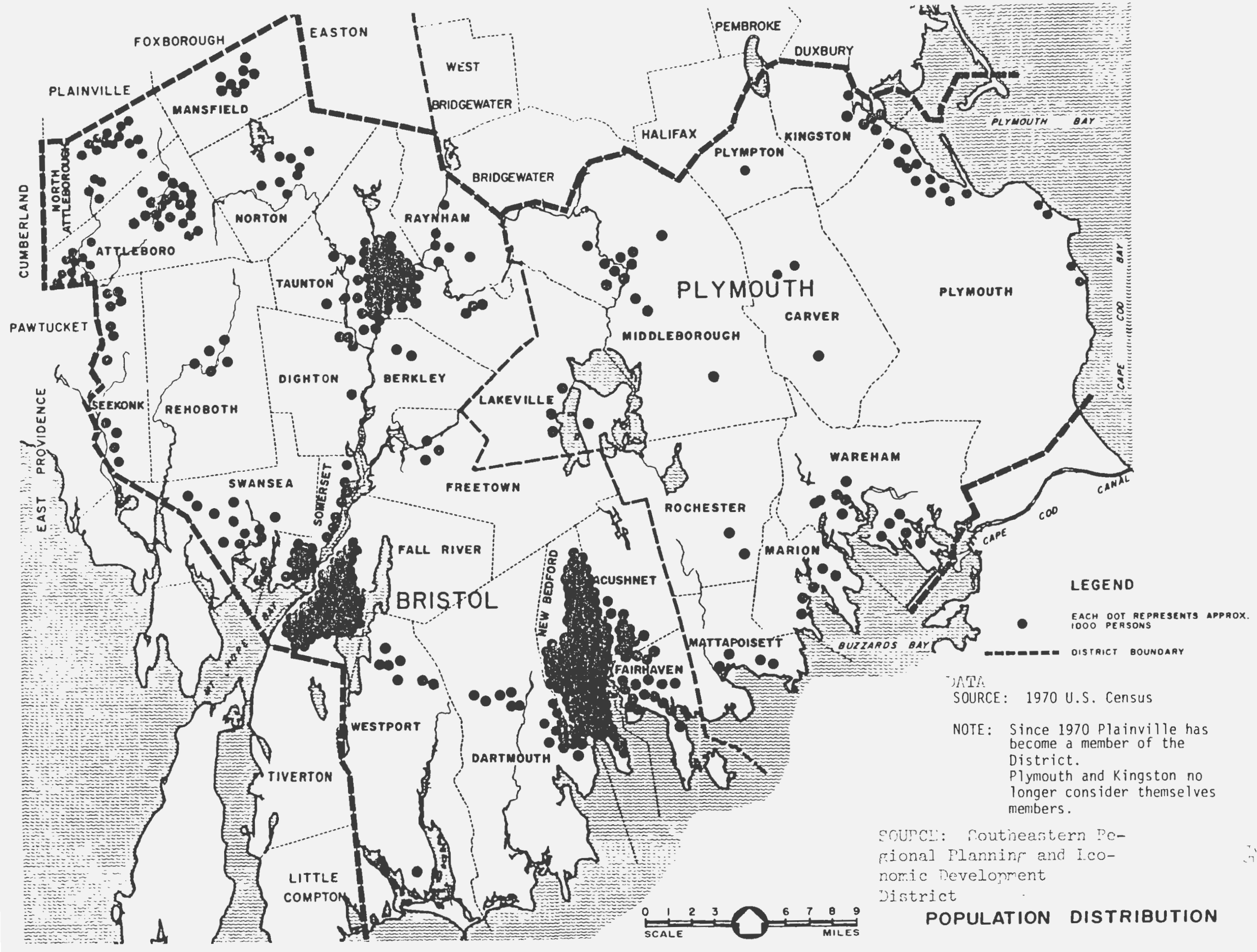


B. Southeastern Massachusetts

The southeast region of Massachusetts has multiple centers, led by Fall

River and New Bedford, each of which has populations of about 100,000.101 Taunton is a smaller city $(45,001)$, similar in function and nopulation characteristics to New Bedford and Fall River. 102 Attleboro, on the suburban fringes of both Boston and Providence, is still growing $(34,221) .103$

Although the shoe and apparel industries have eroded and the entire southeast region suffers from higher unemployment rates than the rest of the state, fishing and jewelry are still very strong industries. The region has three city sponsored industrial parks with excellent highway locations in New Bedford, Fall River, and Taunton. However, these parks compete with one another as well as with privately owned parks such as the "Interstate 95 Industrial Center at 495 " in Mansfield.

Even though double digit inflation and high interest rates have hampered progress, the region continues to make major strides in its efforts to transform the area into a dynamic economic area. From 1966 to 1980, the EDA has invested a total of $\$ 21,159,800$ in the region. ${ }^{104}$ The agency has funded six industrial parks (a \$7.758 million investment): ${ }^{105}$ Fall River Industrial Park; New Bedford Industrial Park; North Attleborough Industrial Park; Plymouth Industrial Park; Wareham Industrial Park; and Taunton's Myles Standish Industrial Park.

Since 1966 the EDA has invested \$10.149 million to improve the infrastructure and other necessary facilities of the four cities in the region. ${ }^{106}$ The impact of this investment can be observed in the many ongoing revitalization efforts in the cities. In 1980 industrial revenue bonds represented an investment of $\$ 60,694,800$ in the region. ${ }^{107}$ Total investment, including industrial revenue bonds, urban development action grants, private investment, and other state and federal grants, was $\$ 89,868,803.108$ 
The refion holds much hope for the acerage available in its industrial parks. Compared to the rest of the nation, Nassachusetts has fared well economically because of the strength of the computer industry concentrated around Boston in the route 128 area.

The high-technology field is one of the fastest growing in the region. In the Taunton-Attleboro-l. ansfield area, nearly a quarter of all the factory employees work in high-technology firms. However, for high level jobs the institutions of higher education serving the region are supplying less than 10 percent of the actual demand. 109

New England manufacturing is becoming increasingly specialized in the production of capital goods such as computers, instruments, aircraft parts, and defense equipment. Consumer goods such as apparel, textiles, and shoes, however, have experienced significant reductions in growth. The high-technology industries are currently leadinf this new growth in production. The growth of the newer industries and services in this part of the country in recent years is an indication of the role of small business in creating jobs. Many of the products produced in New England today did not exist twenty years ago. Studies indicate that two-thirds of all new jobs are created by firms with twenty or less employees. 110 Furthermore, about 80 percent of jobs are created by companies that are four years old or less. ${ }^{111}$

Today, almost 40 percent of the Massachusetts economy employs workers in industries with prospects of rapid growth in the 1980 s. $^{112}$ Because most Massachusetts industries are labor intensive rather than capital intensive, companies are less affected by the lack of equity and debt. The computer manufacturing industry is a good example of a labor intensive industry.

In order for southeastern Massachusetts to follow the steps of the state and New England, it must become more aggressive in its approach to attracting hightechnology and other growing industries. But, it is important that the region 
also maintain its manufacturing base, which still represents almost half of all existing jobs. Retention of existing industries and retraining to suit the needs of new companies will help to stabilize the area's economy.

The population of the region has been growing at a steady pace. This growth is expected to continue, particularly in the smaller towns which are referred to as "bedroom communities" for Boston and Providence. Evidence of suburban movement can be found throughout the region. This is occurring in spite of central business district revitalization projects. The continued development of shopping centers along major highways could, however, prove to be a serious detriment to downtown renewal efforts. Some examples of potentially conflicting interests can be seen in Fall River, Swansea, Dartmouth (New Bedford) and Raynham (Taunton).

The three largest cities in the region are also the growth centers for the region. Fall River, New Bedford and Taunton, maintain a level of economic activity which generates jobs for people in other towns. Similarly, to a large extent, they provide the necessary social and governmental services. In an index ranking 39 cities in the state in order of fiscal constraints (long-term debt; short-term debt; costs of nine selected services; and tax effort) New Bedford ranked 16th, Fall River ranked 19 th and Taunton ranked $24 \mathrm{th} .^{113}$ In the recent past, the three cities have committed large amounts of federal and private funds to revitalize their central business districts and improve their infrastructures.

The region has a number of characteristics which offer great potential for economic development. These characteristics include:114 a plentiful supply of fairly inexpensive land; an abundant supply of water, in comparison with the rest of the state and the nation; a transportation network which offers access to all areas of the region and major areas such as Boston, Providence and Cape Cod; two major seaports, in Fall River and New Bedford; established urban areas with 
available land, building space and other amenities for industrial and commercial development including updated infrastructure; and a versatile labor force, including fairly inexpensive labor. Despite the many positive features the region has gone relatively unnoticed by new or expanding industries. Because of this more effort needs to be put into making the region's attributes known to industry. Some of the region's biggest constraints are beyond local or regional control but follow state and national trends. They include the higher costs of doing business in this part of the nation; generally higher tax rates and insurance premiums; costly and less available energy supplies; and higher shipping costs because of the distance to the new population and market centers in the country.

More specific constraints include: $:^{15}$ a declining manufacturing sector and increased reliance on lower paying jobs; lack of attention to restrictedgrowth or declining industries such as apparel and textile industries; the lack of sufficient manpower training programs to reach the unemployed; and an over reliance on local industrial development commissions which are composed of part-time volunteers.

Two other constraints must be addressed: (1) "Proposition $21 / 2$ " and (2) President Reagan's proposed budget cuts. Proposition 2 1/2 affects all i.assachusetts communities. By cutting city revenues, there may be a strong anti-growth tendency inherent in the statute. Reagan's attempt to cut EDA and other urban revitalization grants could combine with Proposition $21 / 2$ cuts to cause disasterous results in the region's cities. Three of the region's industrial parks are still looking to the FDA for additional assistance to develop more space to attract growth industries. It is unlikely that the region's oldest cities would be able to finance these investments alone. 


\section{Tigh-Icch anä "assachusetts}

The hich-technology incustries in "assachusetts represent the most important element in the overall picture of the :iassachusetts conory. It has rlayed a major role in insulatinf the state from the recession which has nit the rest of

the nation. 116 Because southeastern :assachusetts has, until now, ret witr. little success in acquiring expanding industries from the Poston-route $12 ?$ aree, efforts are now being made to attract industries from the troubled "Silicon Valley" of northern California.

The silicon Valley, named after tiny semi-conductors manufactured with silicon chips there in the late 1960s, grew at a rapia pace. "any of its industries are now looking to expand. The trouble is, the industry has out prown its environs. 117 It has grown so bie so fast that it has used un virtually all the land available for expansion and absorbed all of the local skilled labor. Even worse, dense concentration has driven housing prices in the area so high that the hifh-tecil comnanies can no longer attract the enfineers and managers they neeri from other parts of the country. As a result, many Silicon Valley companies have been looking elsewhere as they prepare for future growth. The things which make prospective new sites attractive are the very thines that the rilicon valley no longer offers: large nools of skilled and trainable labor, affordable housine. for employees and plentiful land for future exransion.

Figh-technology industries in "assachusetts have similar problems, but at nowhere near the same scale. They do, however, worry about where their lahor force is coming from. 113 The industry in vassackusetts gets almost all of its emplorees from in-state, but the state's colleges can't keen pace with the projected demand. 11 A labor shortfall means no crowth, and that could lead to the fradual erosion of the industry here.

To circumvent tinis problem. Fovernor Ldward Kine has proposed a 40 million education and research center designed to make the state more competitive in 
the high-technology field.120 The center is designed to train electrical, mechanical and chemical engineering students, as well as technicians and high-technology industry personnel in the design, development and production of semi-conductor devices.

The Southeastern Massachusetts Economic Development Committee would like to see this center developed, particularly if it opens the doors for high-tech development in their region. The region, like much of the rest of the state, seems willing to place its future in the hands of the high-technology industries. 

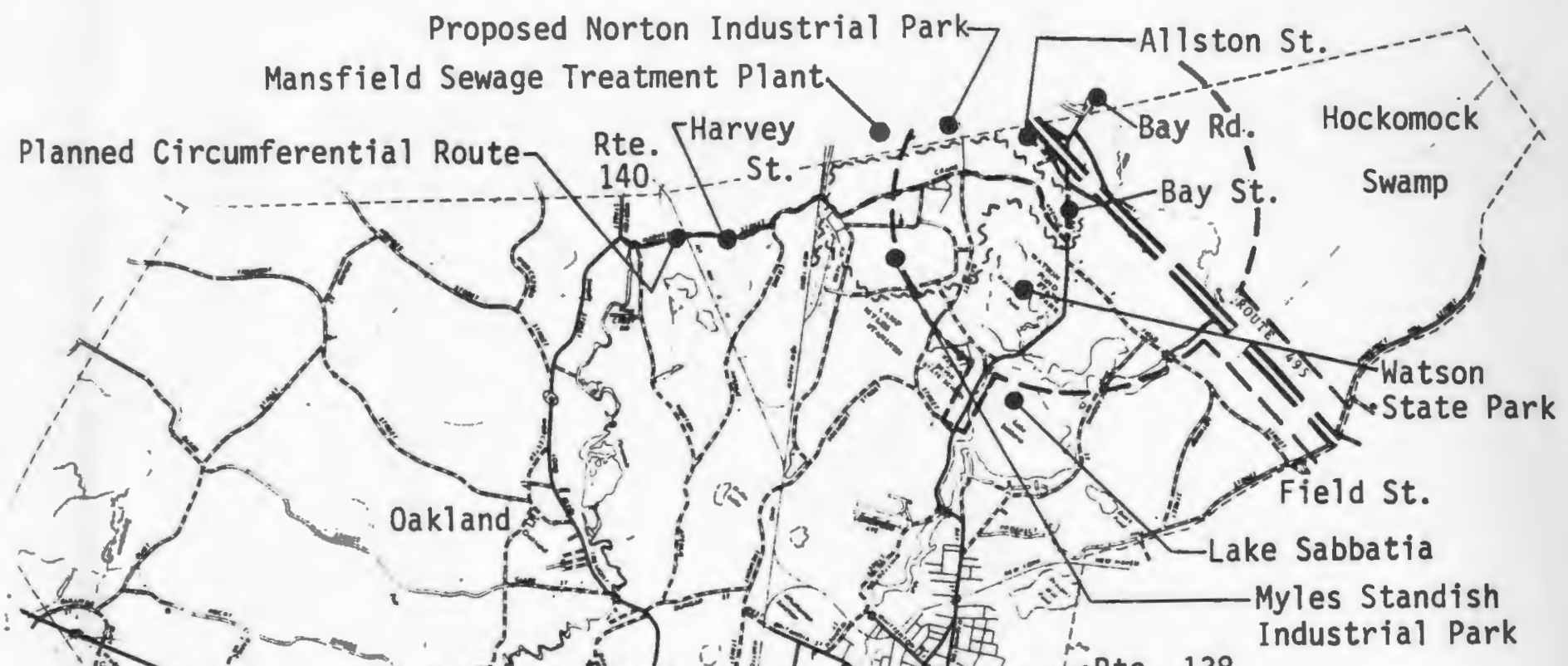

vorth Walker St. HSt Whillage

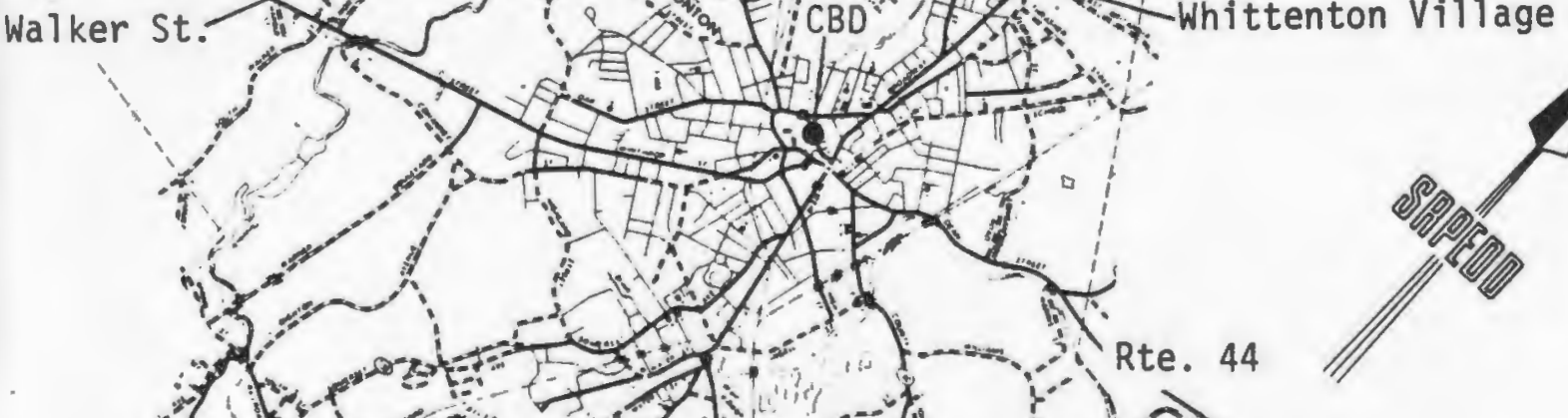

Rte. 138

Treoven ne countegr of the massuchuserts

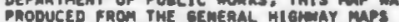

DATED 1975, PAEPARED IY PHE IR BUREAU OF

IN COOPERATIOA WITH THE FEDERAL NIGHAT

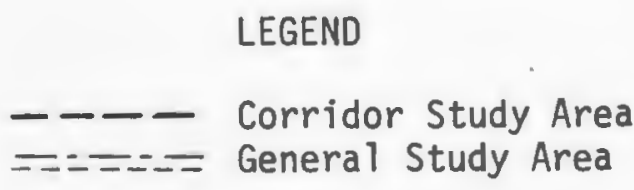

May 1978
AREAS DISCUSSED IN TAUNTON ANALYSIS

SOURCE: Southeastern Re- CITY OF gional Planning and Eco- TAUNTON nomic Development District 


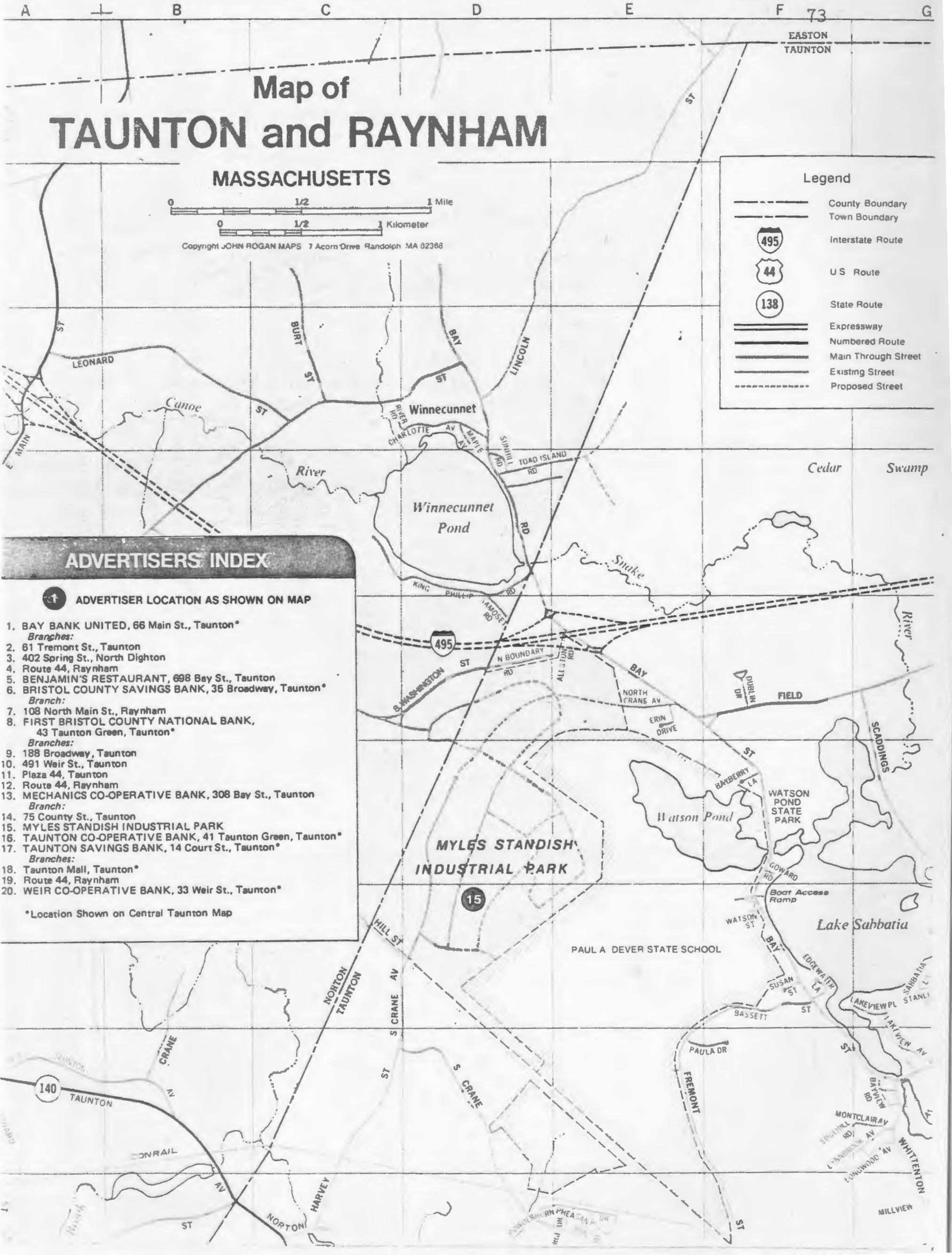


- Desirably Located in the Heart of Southeastern Massachusetts

- Diversified Industrial Community

- Total Land Area - 437 Acres

- Direct Access to Interstate 495 (u.c.)

- Direct Access to Route 140
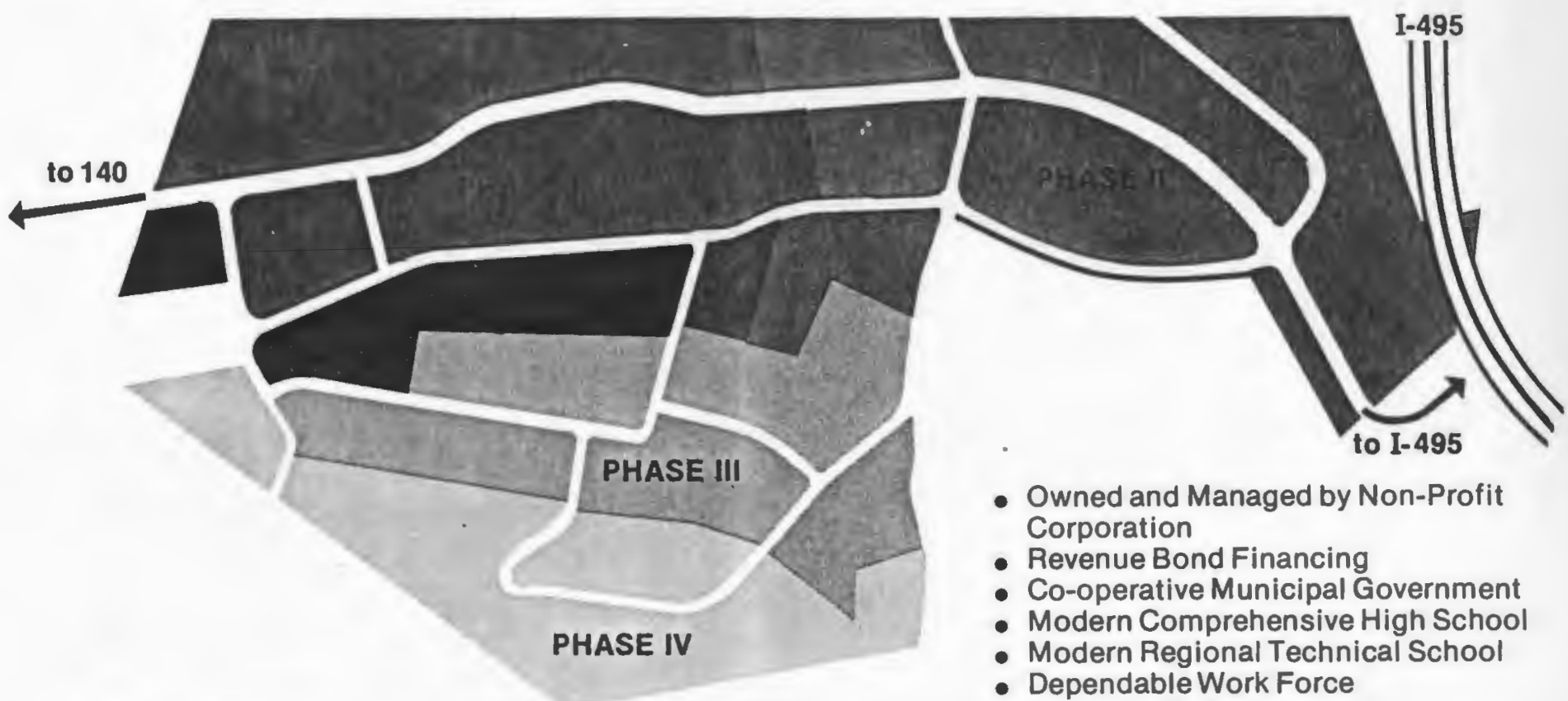

- Owned and Managed by Non-Profit Corporation

- Revenue Bond Financing

- Co-operative Municipal Government

- Modern Comprehensive High School

- Modern Regional Technical School

- Dependable Work Force

- Favorable Suburban Living

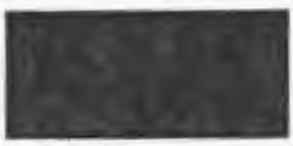

\section{PHASE I - 117 ACRES}

- Available for Immediate Construction

- Reasonably Priced

- Selectively Site Cleared

- Municipal ... Power - Sewer - Water

- Well planned Road Network

- Access to Rail 


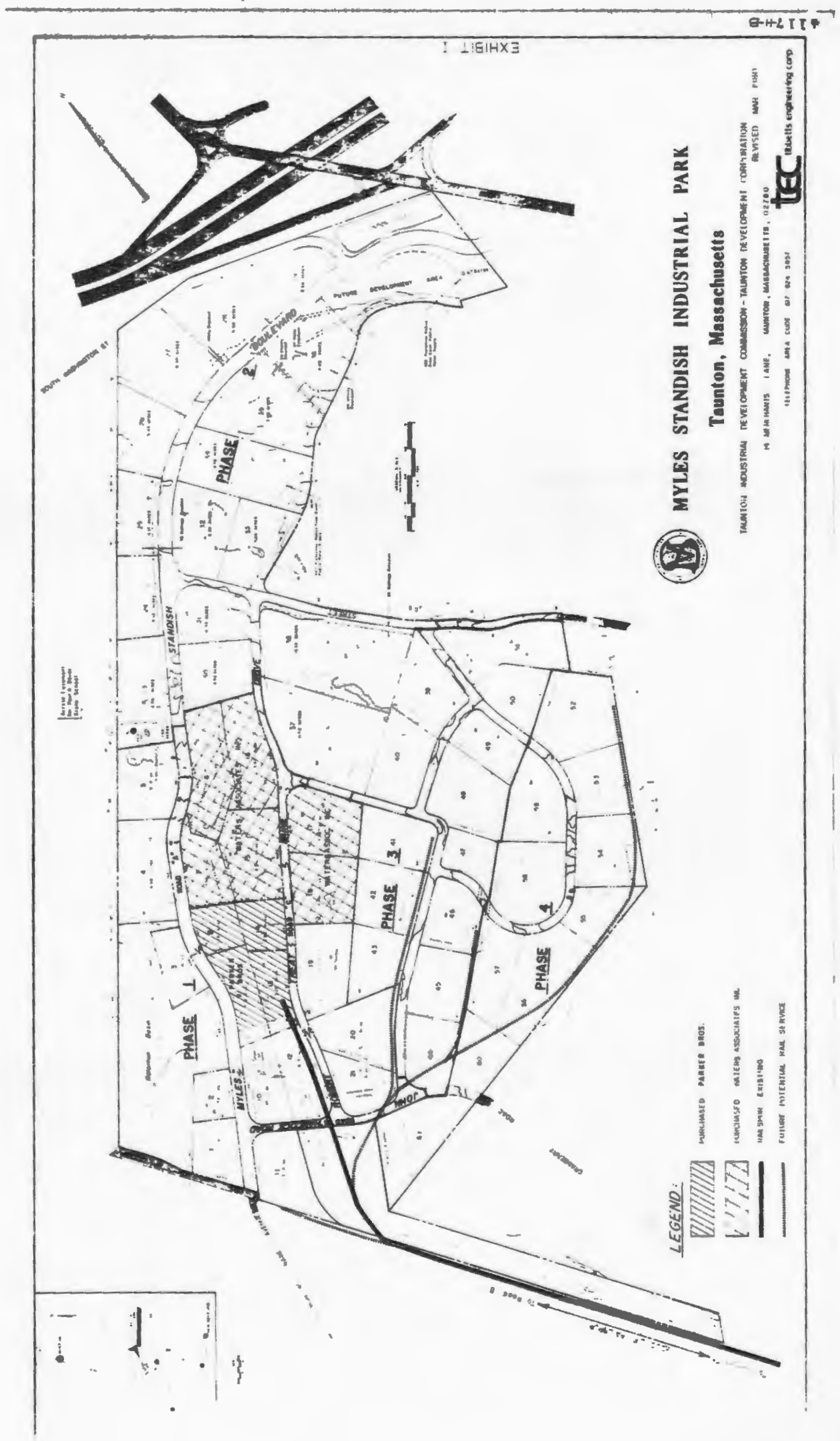




\section{Myles Standish Industrial Park}

Taunton began its push for industrial expansion later than many other industrial cities in Massachusetts. Similarly, its efforts to attract industry lagged behind other cities in southeast Massachusetts. ${ }^{121}$ The first sustained effort to attract industry sprung out of an industrial committee formed under the Chamber of Commerce during the mid-sixties. In 1968 this industrial committee merged with a newly created Industrial Development Commission which began to work on developing industry throughout the city. The Commission was created on the basis of Chapter 297 of the Massachusetts Acts and Resolves of 1954.

In May, 1970, the Taunton Industrial Development Commission was reorganized to play a more active role, and in September James $\mathbb{E}$. Chase was appointed its first chairman. ${ }^{122}$ On May I, 1971, Chase resigned (for personal reasons) and the TIDC was to wait until December before it would appoint its new executive director, William A. McAloon. 123

The Taunton Industrial Development Commission's interest in developing an industrial park near the Paul A. Dever State School was made apparent by its opposition, in late 1972, to a zoning variance request to build 15 homes on Fremont Street - near the perimeter of the talked about industrial park site. 124

The original concept of developing an industrial nark in the northwest sector of Taunton was initiated during the mid-1960s. Mayor Benjamin A. Friedman and State Senator John F. Parker began the negotiations which would eventually lead to the transfer of a large section of undeveloped Paul A. Dever State School property to the City of Trunton.

The State School property totaled approximately 1,650 acres. The site was originally acquired by the United States Army in 1942 to establish Camp Myles Standish, a major embarkation point on the east coast for the troops going to Europe during World War II. ${ }^{225}$ In 1948, with the war ended and attempting to 
divest itself of surplus lands, the federal government deeded the area to the Commonvealth of Massachusetts - to be used solely for the housing and hospitalization of the mentally handicapped. Consequently, the Massachusetts Department of ivental Health would be the eventual recipient of this land. The deed carried the condition that the limitation on use be maintained for a twenty-five year period.

When the twenty-five year period expired in 1973, the community intensified its efforts to acquire a site for industrial park develonment. Farlier, in the fall of 1972, Ratheon had announced the closing of its plant in the neighboring town of Iorth Dighton. Because of the implications for Taunton, Mayor DeSilva organized a task force which was to analyze the impact of this plant closing on the City of Taunton. Wembers of the task force included state legislators, officials of various federal agencies, U.S. Senator Edward Yennedy, and U.S. Renresentative Margaret Heckler of the Tenth Congressional District. Margaret Heckler's involvement was to prove vital to the eventual acquisition of the site at the Paul A. Dever State School site.

When the Taunton Industrial Develonment Commission first began to negotiate with the state for acquisition of the land, it spoke in terms of acquiring more than 700 acres of land. The negotiating process was to whittle this amount down to the eventual 437 acre site. Because it was state property, lepislation was needed to transfer the deed to the City of Taunton.

$$
\text { Mayor Theodore Aleixo, Jr., } 126 \text { Representative Raymond J. Boffetti and }
$$

Senator John F. Parker filed the initial lefislation to have 571 acres turned over to the city for use as an industrial site. The plan met with stiff resistance from the State Denartment of Mental Health and the school trustees. ${ }^{127}$ While city and state officials were involved in negotiations concerning the land, legislation stalled in the House Committee on State Administration. ${ }^{128}$ This committee was chaired by Representative John J. Long of Fall River. ${ }^{129}$ 
Long and House Speaker David M. Bartley suggested that Taunton be required to pay the Department of Mental Health for the land it wished to accuire. The suggestion stimulated a sharn debate between Aleixo and Bartley on the House floor. ${ }^{130}$ Representative Donald J. Manning of Waltham moved for reconsideration arguing that the measure should contain a stipulation that the property should be anpraised to determine its actual value. Aleixo debated hanning for over one hour. When the motion to reconsider was put to a vote, it was rejected by a 17145 margin.

Eventually a compromise agreement was worked out whereby Taunton would pay the state $\$ 1,200$ for every acre which the city sold. ${ }^{131}$ while this was more than the $\$ 800-\$ 900$ the city had proposed paying, the House was still not prepared to approve the legislation without further information. With time running out for EDA grant application approval the House requested, during a Thursday session, two independent appraisals of the value of the land - and they wanted this information by the following Monday. 132 It was done.

The Taunton Industrial Development Commission had received $\$ 15,000$ from the Economic Development Administration in June of 1973 to aid in planning for the location of an industrial park at the Dever State School site. ${ }^{133}$ The unsettled status of the legislation needed to acquire the land was now holding up action on a $\$ 900,000$ grant application to develop the site. The EDA would not award any funds until the city held title to the Dever land - this in turn prevented the city from borrowing funds to match the anticipated EDA grant.

After months of meetings and hearings marked by stiff resistance, the city acquired the land on June 24,1974 - six days before the June 30, 1974, deadline set by the Economic Development Administration. ${ }^{134}$ In that six days finalized EDA grant applications were hand-carried between Taunton, Boston, Washington and Philadelphia to get appropriate signatures and reviews. 
One of the reasons the Dever Land Bill was approved was the unprecedented agreement reached between the state and the city. ${ }^{135}$ Taunton agreed to work to guarantee that ten percent of the jobs created at the industrial park would be filled by residents of the Dever School. The city also agreed to provide safeguards for the Dever School residents along the Penn Central railroad tracks which run through the land. In a separate agreement signed by the Commissioner of the Department of Mental Health and local maunton authorities, the city agreed to: (1) maintain services for the mentally retarded, such as clinical advisories and sheltered workshops; (2) include representatives of the Department of liental Health and the Dever State School on the governing board of the proposed new park; (3) seek funding for training programs for retarded citizens; and (4) guarantee at least ten percent of the positions at the industrial park to retarded people. ${ }^{136}$ The EDA grant was approved in the amount of $\$ 858,000.137$ Representative Margaret Heckler's position as a member of a House Committee dealing with the Defense Department helped to secure the first funding for the project by obtaining the support of the Department of Defense for the proposed acquisition of the former Camp Standish site. 138 Six months later the city obtained a second grant of $\$ 421,800$ to aid in the construction of additional public works. 139

As this entire process was unfolding other important decisions were being made which would affect the proposed park development. Of critical importance to the success of the park was the proposed plan to extend Interstate 495. The tentative plans called for the road to pass through north Taunton very close to the site. The extension of 495 was to complete the loop around Boston by constructing 16 miles of new interstate between Interstate 95 in Mansfield and route 25 in Bridgewater. The Southeastern Regional Planning and Economic Development District Commission considered this to be the "missing link" that would open up southeast Massachusetts to industry and business. 140 Similarly, this roadway would be crucial to the success of the industrial park being planned for Taunton. 
On February 27, 1974, Governor Francis Sargent appeared at a meeting at the Department of Public Works offices in Taunton and assured the community that funds would be set aside for the road. 141 Sargent also indicated that the "link" would be placed at the top of the Commonwealth's priority list for federal funds from the Department of Transportation. 142

There were, however, long delays before the federal government authorized an Environmental Impact statement for the proposed project. By this time Michael Dukakis was the Governor of the Commonwealth, and he appeared to be only mildly interested in seeing the roadway completed. 143 At a meeting attended by Governor Dukakis and state transportation and public works officials, the SRPEDDC made a very strong push for the roadway. 144 SPPEDDC cited the positive benefits which the region would derive from this roadway. Dukakis approved the extension in lay of 1976.

Those opposed to the highway were mostly concerned with its affect on wetlands, wells, and property values in the area. The Environmental Impact Statement was accepted for the entire roadway, with the exception of a decision concerninf the location of one interchange which the Town of Norton and the City of Taunton disagreed on. Six alternatives were eventually boiled down to two possible locations. Taunton, quite naturally, wanted an interchange which would intersect with Bay Street, thereby providing direct access to its industrial park site. Norton wanted the interchange placed further to the west in order to provide access to an industrial park site which it hoped to develop - also on Dever School pronerty. The Bay Street interchange was accepted and Taunton's proposed industrial park came closer to being. Construction of the "missing link" began in 1977 and is expected to be comnleted sometime this fall. 145

The evolving role of the Taunton Industrial Development Commission was 
also noteworthy. During the period from July, 1974 to October, 1977, the Commission was supported by an FDA technical assistance grant of $\$ 104,000.146$ This money was appropriated in order to broaden the scone of the Commission in its effort to attract industry to the city, and to assist in expansion efforts of existing firms in the city. 147

As early as 1973 the Commission began to realize that the industrial park would best be managed by a non-profit corporation. 148 The commissioners of the Taunton Industrial Development Commission went before the Municipal Council and proposed the concept of a non-profit corboration made up of members of the Taunton business community. This proposal was adopted by the Council and approved by Mayor Rudolph Desilva in August of 1973. 149

The directors of the new corporation were selected by the fifteen commissioners of the Industrial Development Commission. Sixty candidates were narrowed to fifteen finalist from whom the 11 members and 9 directors were selected. The directors of the new corporation came from a broad segment of the city's business community: ${ }^{150}$ Joseph I. Quinn, owner of the Alan Walker Insurance Co.; Robert $W$. Boyden, former president of Boyden Plastics; Joseph C. Murray, president of the Taunton Cooperative Bank; Edward A. Roster, a local attorney; Harry H. Carey, a board member of the First Bristol National Bank; Addison L. Jannings, a local CPA; Stuart W. McBride, chairman of BayBank United; Charles Colton, a trustee of the Dever School; William C. O'Connell of Taunton-Davol Printing; Charles E. Volkman, executive vice president of the Chamber of Commerce; and Sinclair Weeks, Jr., chairman of the board of Reed and Barton. Quinn was named chairman of the Taunton Development Corporation, a position he still holds today.

Three other directors were also added to protect "the interests of the city": the mayor in his or her term of office; the president of the Municipal Council in his or her term of office; and, the chairman of the Industrial Development Commission. 
By 1974 the Industrial Development Corporation had been formed and was beginning to play an active role in the industrial park project. But legally the corporation did not have the real authority to make decisions. ${ }^{151}$ During the later part of 1974 and 1975 an agreement was worked out between the Industrial Development Commission, the Development Corporation, and the Municipal Council. The autonomous nature of the Development Corporation was authorized by the Municipal Council in October of 1975 and received the final approval of the Council in June of 1976.152 The management agreements which gave the Development Corporation total management responsibility including development, marketing and management of the park, was formally signed in October of $1976 .^{153}$ At this time the 437 acre site was deeded to the corporation.

Giving control of the site, and project, to a non-profit corporation meant that future EDA grants would be made directly to the corporation rather than through a city agency. The result of this would be that future investment, which would require $30 \%$ matching funds, would come from the corporation rather than from the city itself. ${ }^{154}$ This way the corporation, not the city assumes the costs. ${ }^{155}$ The management agreement stipulated that the sale of land would be the corporation's only source of profits and that these profits would be reinvested in the continuing development of the park. The corporation was able to establish a line of credit, with community banks, of over one million dollars - based on the park's potential value.

The first development plan for Myles Standish was prepared by the Taunton Industrial Development Commission and a task force made un of representatives of those city agencies whose services would be involved. The master plan for the 437-acre site called for development to proceed in four nhases, each phase consisting of approximately 100 acres. The development time-table for each phase would be dependent on the marketing success of the previous phase. ${ }^{156}$ Preliminary engineering for a new phase would begin when $50 \%$ of the land in the previous phase had been sold. 
Because of the location and attributes of the site, the Commission and its task force decided to develop a garden-style industrial park. The basic concept in a garden-style park is to preserve wooded areas, encourage landscaping and design buildings and sites so that they are integrated into the natural landscape. The original plan was produced by using aerial photographs of the area. Governing the companies' landscaping and building plans are a set of deed restrictions or standards, adopted by the Taunton Development Corporation on April 14, 1978. Companies must have written approval from the TDC before any construction of site improvements can begin. The twenty-four deed restrictions serve to reinforce existing municipal and state zoning ordinances and regulations. They are designed to protect the intent of a garden-style industrial park and prevent poor design or maintenance from detracting from the value of neighboring facilities. In developing these covenants and restrictions a blend of several sample restrictions, obtained from the Association of Industrial Parks, was used by the Development Corporation.

In December of 1974 engineering got underway for the development of the approximately 117 acres included in the first phase of Myles Standish Industrial Park. This area was to be developed first because of its access to Crane Avenue, (keep in mind - the interstate was not even approved at this point) which provides access to route 140, and its proximity to an abandoned railroad right-of-way which might someday provide rail service to the park. ${ }^{157}$

Up and until the fall of 1975 the industrial park carried the simple name of "Northwest". However, this was a temporary name used because of the need for a name when filing for the EDA grants. 158 Therefore, a contest was developed whereby Taunton High School students would choose a more appropriate name and logo for the park. A committee, consisting, of three members of the local news media, selected the name Myles Standish because of the historical value of the name. 159 
Three EDA grants were authorized and three contracts awarded by October of 1975: one for the on-site work; one for the off-site sewer main; and one for the off-site water main. Over a ten-month period in 1976-1977 a \$94,000 grant was used for selective site clearance in the Phase One area. ${ }^{160}$ Construction for the large infrastructure grants was begun in the spring of 1976 and completed by late 1977. Two other FIDA grants, totaling $\$ 1,479,000$, were used to construct a 20,000 lineal foot 12-inch water main; a 15,000 lineal foot sewer main; 6,600 lineal feet of road surface; a surface drainage system; and street lighting. ${ }^{16 l}$ The first phase of development was completed by 1978 with federal and city sponsored EDA grants. But certain additional work and the work for Phase Two would be the responsibility of the Taunton Development Corporation. One of the major accomplishments of the corporation was to make rail service available to sites in the park. This was accomplished in large part because of funds left over from an IDA Erant for a water main tie-in on Ray street. The corporation had to convince the EDA that the original grant wasn't so much for the water main as for the development of the park. 162 of the total cost of $\$ 550,000$, approximately $\$ 250,000$ came from the left over grant money and $\$ 300,000$ from the corporation. ${ }^{163}$ The money exrended by the corporation was obtained through the sale of land in Phase One of the develonment. The Taunton Punicipal Lighting. Plant purchased the abandoned railroad right-of-way that originally served Camp Nyles Standish. The utility then installed a new distribution system and provided the Development Corporation with an easement for the construction of a 9.000 lineal foot rail spur, which would connect with the existing line.164 Approximately 100 of the park's 437 acres can be served by this railroad spur. The main segment of the line was provided by the corporation, but the remaining tie-ins are the responsibility of the firms buying, the land. Another important project which the corporation was directly involved in 
was the development of a loop water system which both the fire department and industries considered essential. It involved constructing 6,000 lineal feet of water main from Norton Avenue, up Harvey Street and into the park at a cost of $\$ 165,0000^{165}$ A third project involved a change in the sewer interception. Although the park is tied into the city sewer system, at the time the lines from the park were tied into others, including those from the Dever State school. The cost of separating the park's lines from all the others was $\$ 130,500$ for the 4,000 lineal feet of line. 166

On June 23, 1978, Myles Standish Industrial Park was officially dedicated. The program included ground breaking ceremonies by Boyden Plastics of Taunton, and Waters Associates, Incorporated of Milford and Taunton - the two seed tenants in the park. Boyden Plastics, a division of General l.'ills, through the Parker Brothers Came Division, has constructed a 55,000 square foot manufacturing facility which emnloys almost 200 persons on its ll-acre site. 167 waters Associates, Inc., a designer, manufacturer and marketer of high performance liquid chromatograrhy instruments, accessories and supplies, has constructed a 32.000 square foot material synthesis building, where about 50 people are employed. ${ }^{168}$

In 1978 and 1979 the TDC sold 43 acres of land in the Phase One area of the park. Because of this progress, the EDA approved a grant for the development of Phase Two of the project, in the amount of $\$ 1,687,000.169$ The second phase was planned to complete the road network and utilities in time to coincide with the completion of Interstate 495. Phase Two involved the development of another 120 acres of land, concentratine on the road network connection with Bay street and, in turn, with the Bay street interchange on route 495.170 This interchange borders the northeast corner of the park's land. Also included in this phase was the establishment of a 2.1 million gallon water storage standpine to help the fire flow; an additional 20,000 lineal feet of underground utilities, includinf sewer and water lines, and underground wiring for liçhting. 171 
Now that the first two phases of development are nearly completed, the emphasis must be turned to the marketing of Myles Standish Industrial Park. With the opening of the route 495 interchange just months away, the park has sold a total of approximately 50 acres, to three tenants. I'he recently acquired third tenant is the Fepsi-Cola Bottling Froup, a subsidiary of Pepsico, Incorporated. Pepsi-Cola is in the process of constructing a 41,200 square foot building for warehouse and distribution use on its 7.1 -acre site. 172

The sites which companies may purchase are designed to be quite flexible. On plat maps of the area the building sites are shown as "paper lots", to give a rough estimate around which the roadwork and utility placements could be planned. The idea is to give a rough idea of how typically sized lots might appear in the completed park. This was necessary for the administrative approvals which the park required from the Economic Development Agency and the local planning board. ${ }^{173}$ The actual sizes and configurations of the lots are determined when the tenant purchases the land. Land prices in the Phase One area are set at $\$ 15,000$ an acre for land with no access to rail and $\$ 20,000$ an acre for land with access to rail. Land in the Phase Two area sells for $\$ 22,000$ an acre. Once the route 495 interchange is opened land prices in the park will probably average more than 25,000 an acre. 174 There are four groups involved in the marketing, of :iyles Standish: the Taunton Area Chamber of Commerce, the Taunton Industrial Development Commission, the Taunton Industrial Development Financing Authority, and the Taunton Development Corporation. The TIDC is responsible for attracting industry to the entire city, while the TDC is concerned only with the marketing of Hyles Standish Industrial Park. The Financing Authority handles industrial revenue bonds. The staterefulated revenue bond profram allows industry to borrow money for new development, or expansion, at low interest rates by using the city's credit as backing with the firm taking complete responsibility for repayment. The four groups mentioned above share offices in a downtown Taunton location. 
William McAloon plays the key role in the marketing, process. McAloon wears several hats - he is a member of the board of directors of the Taunton Development Corporation, secretary ex officio of the Taunton Industrial Development Financing Authority and executive director of the Taunton Industrial Development Commission. licAloon was named executive director of the TIDC in December of 1971. Prior to this he had worked as an administrative assistant to Mayor Flood since October of 1970. The majority of his career had been spent in various sales positions. His employers included the Taunton Gas Light Company in the 1930s and 1940s, and the Roper Company (which would eventually be sold to Sears) in the 1950s and 1960 s.

The actual marketing of the park is done by the Taunton Industrial Development Commission. Their role is to bring industry to all of Taunton. However, because of budget constraints, staffing is a problem. The TIDC has run about twenty ads a year in national publications. 175 Because of Proposition 2 1/2, the TIDC promotional budget has been cut, thereby reducing this number as well. As for personnel, Richard Bettencourt is the only person involved in the active promoting of industrial sites in Taunton. Bettencourt spends four days a week on-the-road making cold-calls on a predetermined list of industries. This list includes the high-tech industries around Boston and companies included in the one hundred leading growth industries. The objective as McAloon describes it is "to expose Taunton to these industries".176 A similar strategy has been used in the past with directmailings and target-mailings, designed to "get this information into the files of the important people". 177

The Taunton Industrial Development Commission's marketing packet includes a detailed profile of the city, a phamphlet setting forth the covenants and restrictions in effect at pyles Standish, a reprint of a Northeastern Industrial World article on Myles Standish Industrial Park, and various mans showing the region, the city, and the industrial nark layout itself. The amount of money allocated to the TIDC has been minimal because of the city's fiscal situation, and because of 
the city's desire to wait until I-495 was closer to completion. McAloon himself admits that "some people haven't been satisfied with the speed with which the park has been developed", but points out that the overall plan is a long-range one designed to ensure a park which is beneficial to the City of Taunton. ${ }^{178}$ McAloon feels that I-495 is the catalyst. "We have had considerable interest in Phase Two of the park and action has now come alive on the Bay Street interchange."179

Recent action by local administrators may prove beneficial to the development of Myles Standish. In the fall of 1981, the previous mayor, Joseph M. Amaral, doubled the TIDC funding because of the impending completion of Interstate 495.180 Originally it was felt that the Taunton Development Corporation should give an "exclusive" to an industrial realtor, but it was decided that such decisions should be postponed until the newly elected mayor, Richard Johnson, could offer his imput. $^{181}$

Even more important to the City of Taunton and the region has been the recent formation of the Southeastern Massachusetts Economic Development Committee. The committee, which includes government officials and industry leaders from raunton, Fall River and New Bedford, is trying to attract industries to the southeastern area. The committee has spent about $\$ 150,000$, largely for travel expenses and mass mailings to one thousand companies. ${ }^{182}$ Each community raised about $\$ 30,000$ from a combination of community block grants and local business development organizations; that, coupled with $\$ 40,000$ in state funds and the balance in private contributions, sent a group of about one hundred representatives to California to try and convince high-tech industries to expand in southeastern Massachusetts. 183

The group faces an uphill battle against low-tax states, the sun Pelt, and states like the Carolinas which offer lucrative incentives that most New Fngland states cannot match. Vore than one hundred industries were invited to meet with the proup in California, but only thirty-nine sent representatives. 184 
Fight of these industries have agreed to tour the southeastern Massachusetts region within the next few months and consider it as a spot for expansion. If nothing else, the trip to California has allowed Taunton to update its promotional materials with a $\$ 40,000$ grant from the Private Industrial Council. 185 That process is now underway and should be completed by the summer.

If I!cAloon and the Taunton Industrial Develonment Commission are correct, the next few months should nrove to be most influential to the final development pattern of Myles Standish Industrial Park. 
F. Recommendations and Comments

The following comments and recommendations are based on the analysis of Mvles Standish Industrial Park, using the criteria set forth in section II of this paper. Nany of the issues overlap the five areas of review: Site Selection, Management, Attractinf Industry, Marketing and General Issues.

Site Selection.

1. Regional Setting. The concept of an industrial park to serve southeastern Massachusetts was and remains a good one. The region needs additional industries and the employment which they bring. Locating the park in the northern part of the region made good sense because of its proximity to the route 128 growth area. On the other hand, the competition from the Cabot, Cabot and Forbes "Interstate 95 Industrial Center at 495" in lansfield should have been anticipated. However, because the need to create jobs and additional tax revenue was and still remains important, the selection of Taunton was warranted.

2. The Specific Site. While I-495 provides excellent access to the site, certain problems must be addressed. The specific location of the park and the highway interchange may place pressures for develonment on environmentally sensitive land, farmland, and residential areas currently zoned for low-density development. Traffic flow from I-495 and Myles Standish Industrial Park will place pressures on Bay Street and adjacent lands and neighborhoods. Similarly, the western access to the park, Harvey Street, may not be able to hande Myles Standish traffic and I-495 traffic which will use Myles Standish Industrial Park as a method of getting to route 140 and the Oakland neighborhood area. This may place additional pressures on Bay Street.

The site itself is an excellent physical specimen, and the style and layout used is practical and efficient. Generally, layout and utilities in industrial parks are designed for the specific type of client the management wishes to 
attract. It is unclear whether a specific group of industries has ever been targeted for the park.

The selection of the specific site was, of course, determined because of the availability of the Dever School land and its proximity to the proposed I-495 extension. None-the-less, alternative sites should always be considered in such large scale developments. Were there other suitable sites in the city which would have required less infrastructure costs and would have been more consistent with surrounding zoning? Obviously, I-495 makes this site very attractive, but alternatives may also have been attractive and required fewer capital investments.

Management.

1. Structure. The concept of private non-profit management is ideal. It reduces costs to the city and allows for reinvestment of all profits from the sale of land. It is unfortunate that the Taunton Development Corporation was not the original developer of the project. By turning over control at such a late stage, the city was made to bear the costs of $\$ 1.6$ million in matching funds for the Economic Development Agency grants.

One alternative would have been to allow a private developer to manage the project. Private manafement could offer more money for marketing of the park. It would also provide experienced professional approaches to marketing and management. Similarly, private funding would have made development of spec buildings likely, aplus for the eventual marketing of the park. Since the issue at hand is creating jobs and producing additional tax revenues, the profits on sales of land is a secondary issue which must be considered a trade-off to the ability of the private developer to produce results (jobs) in a shorter time frame.

2. Issues. The Taunton Development Corporation must define its longterm management plans more clearly. It must protect the city from having to absorb 
management responsibilities in the long-term. This might be done through a welldesigned tenants association which would assist the Taunton Development Corporation in monitoring on-going development of the park.

Management should spell out the type of industry they are seeking to attract. This list would ke based on a market study of industries, their growth potential, their requirements and their potential benefit to the community. This study should have been conducted prior to development of the park.

The covenants for the park are well thought out and show an obvious concern for the overall development plan. Sign specifications should be more specific, outlining size limitations and acceptable materials permitted in design of signs.

The phased develonment scheme is most logical. However, plans should be developed for determining what guidelines will be used to determine whether additional development is warranted. How long will undeveloped land be held, and what additional uses would be acceptable for such land?

The seed tenants in an industrial park often set the tenor for development. The seed tenants should be strong industries capable of generating interest (in the park) on the part of other growing industries. The seed tenants in this case may not have been strong enough to warrant the initial development costs. More, or stronger, seed tenants should probably have been considered. Particularly when one considers the competition ten miles up the road in Mansfield. The Taunton Development Corporation must also address the agreements made with the State Department of Mental Iealth and the Dever School authorities. Provision for implementing these agreements must be developed so that no negative public relations develon from this situation. To date, William licAloon of the Taunton Industrial Development Commission has done a superb job of maintaining good relations between local residents and park management. 
r.anagement must also address the issue of marketing. This will be discussed in further detail on the following nages.

\section{Attracting Industry.}

1. Taunton's Potential. Trunton appears to fulfill the requirements thich industrialists seek when locating their firms. There is an otvious supply of ready labor, low wages and housing in the area.

2. Issues. Despite the labor supnly, an emphasis should be placed on training programs designed to meet the needs of industry. The city and the region should support the King, proposal to develop a high-tech training college. Support should also be given to improving and exnanding existing technical schools and universities abilities to produce high-technology required skilled workers. This would also result in higher wage jobs for the community.

The regional approach to attracting industry should be maintained and expanded. The increased funding potential means increased contacts - this is most important to marketing success. Attracting industry to the region will benefit all the communities of the region.

When attracting industry, the city should stress not only land, utilities, labor force and wages, but locational qualities that make the city a nice place to live. This would include recreational opportunities available on Cape Cod and Narragansett Bay. Proximity to the Boston area and the mountains and lakes of northern New England might also be stressed.

Marketing.

1. Competition. The people of Taunton would like to see Myles Standish Industrial Park developed in a fashion similar to the Cabot, Cabot and Forbes park in lansfield. The two parks have actually competed for industry in the last few years, with the winner being quite apnarent. The Mansfield park still has 300 
acres which will be developed and marketed during the next five years. This means that Mansfield will be comneting with Myles Standish's 200 acres which will be available at the same time. T'he need for increased nrofessional marketing of Nrles Standish is apoarent.

2. Issues. The most apparent problem with the current marketing procedure is the lack of appropriate funding. After investing millions of dollars to develop this site, the Taunton Develonment Corporation and the maunton Industrial Develonment Commission are now marketing the site on a shoe-strinf budeet. The results are apnarent - one tenant, a distribution service, in the last four years. If the potential benefits of Myles Standish Industrial Park are so great, then a larfer marketing budpet will obviously pay for itself in a short time.

The Taunton Development Corporation should play an active role in the marketing of the park. Development of a phase of the park is dependent on the success of the marketing of the previous phase. The marketing process might actually be considered a nart of the development costs, and therefore the Develonment Corporation should be willing to bear this cost. Additional exnerienced professional staff is needed.

The marketing of the park should have begun in earnest at a much earlier time. Furthermore, it should have been more efficiently conducted given the size of the marketing budget. A shotgun approach to marketing provides few returns when the gun can only be loaded once.

The use of local real estate brokers should be ongoing. Meetings should be held periodically to remind ther of the park and its availability. This is narticularly important given the weak marketing effort currently used.

Development trins such as the recent California excursion are expensive but usualy more nroductive than other forms of unsolicited contact. The regional concent should be maintained and possibly exnanded upon. 
The use of cold-calls on industry is Eenerally ineffective. It reflects the insufficient fundins provided for marketing a multi-million dollar project.

General Issues.

There are several general issues which must be addressed:

The community could have required much more examination of the orifinal concept of development. maunton subdivision requlations allow for possible environmental and fiscal imract analysis to determine costs as well as henefits of development. This, quite obviously, should have been done with the park to determine the effect of new growth on service requirements such as police, fire, nublic works, schools and reneral government. Whe community should consider this at the present time in order to detcrmine future develonment-inspired services and the communty's akility to provide them in light of Proposition 2 1/2.

The communit: must maintain the develoment of its central rusiness district as its number one nriority. Increased industry is of little value if the downtown arca is allowed to depreciate, thereb" harming the "nuality of life" for resirients of the community.

The city must work to discourage snrawl. Growth policies must be defined so that the community can respond to future $I-495$ and 'yles ctandish Industrial Park induced develonment pressures. The potential for develoment of sensitive areas is great and must be dealt with.

Public transportation must be considered for travel to the parl: from. various areas of Taunton. This can heln to reduce traffic flow in sensitive areas.

Decommendations.

Fecause of the scattered annroach to zoninf anrarent in Taur.ton, the nari: my actually helr the city zoning process by reducing pressures for industrially zoned lands. 
The following recommendations are provided:

Bay Street Area. The current low-density residential development should be maintained so that aquifers, wetlands, conservation lands and other sensitive areas are protected. A specialized business district serving motorists and Myles Standish Industrial Park should be directed to the area fronting the park entrance. Driveway access to streets leading to the I-495 interchange should be restricted. Farmland. The community should consider preserving farmland which would be susceptible to development pressures. This could be done through the purchase of development rights and the implementation of the Farmland Assessment Act.

Open Space. The community should protect wetlands through the establishment of a wetlands zoning district which would back up existing state legislation. Purchase of development rights to open space should also be considered. Mapping and zoning to protect aquifers and wetlands should be encouraged.

Transportation. Traffic flow south on Bay Street should be reduced by encouraging travel west to route 140 . This could be done by using signs to direct traffic through the Myles Standish area. This would necessitate improvements to Harvey Street.

Interchanges. Special permit process should be encouraged for all non-residential development within a prescribed distance of the interchange. Another possible alternative is to impose a moratorium on certain types of development in these areas until the city can decide how to cope with the growth. Growth Policy. Consideration should be given to the growth policy recommendations set forth by the Southeastern Regional Planning and Economic Development District Commission. 
The following information is taken from an article entitled "Manufacturers' Attitudes Toward Industrial Development Information", originally published by the Office of Industrial Development Studies, University of Missouri, in October of 1970. The paper is reprinted in Guide To Industrial Development, edited by Dick Howard, published by Prentice-Hall, Inc. (Englewood Cliffs, N.J.), in 1972 .

Source Attributed With Presenting Site Ultimately Selected.

\begin{tabular}{|c|c|c|c|c|c|c|}
\hline & \multicolumn{3}{|c|}{ Town Size } & \multicolumn{3}{|c|}{ Company Size } \\
\hline & Total & Urban & Small & Large & Med. & Small \\
\hline Internal & 1 & 0 & 1 & 0 & 1 & 0 \\
\hline Chamber & 19 & 2 & 17 & 11 & 2 & 6 \\
\hline Utility & 2 & 2 & 2 & 2 & 0 & 1 \\
\hline State ID & 6 & 0 & 6 & 2 & 1 & 3 \\
\hline R.R./Trans. Co. & 3 & 0 & 3 & 2 & 1 & 0 \\
\hline Consultant & 3 & 2 & 1 & 2 & 1 & 0 \\
\hline
\end{tabular}

Unsolicited Contacts By Industrial Developers And Manufacturers' Attitudes.

$\begin{array}{ccc} & \text { Personal } & \text { Telephone } \\ \text { Manufacturer's Opinion } & \text { Visits } & \text { Calls }\end{array}$

\begin{tabular}{lcc}
\hline Very Useful & 7 & 2 \\
OK & 11 & 11 \\
Not useful unless project & 30 & 31 \\
$\quad$ for area underway & $\frac{52}{100 \%}$ & $\frac{56}{100 \%}$ \\
Not useful & 46 & 45 \\
Number of respondents & & 45 \\
\hline
\end{tabular}


Manufacturers' Attitudes Toward Unsolicited Contacts By Industrial Developers By Size of Company.

\begin{tabular}{lcccccc}
\hline Manufacturer's Opinion & $\begin{array}{c}\text { Personal } \\
\text { Visits }\end{array}$ & \multicolumn{3}{c}{$\begin{array}{c}\text { Telephone } \\
\text { Calls }\end{array}$} \\
\hline $\begin{array}{l}\text { Large } \\
\text { Very useful }\end{array}$ & 3 & 0 & 33 & 0 & 0 & 20 \\
$\quad$ OK \\
$\begin{array}{l}\text { Not useful unless project } \\
\text { for area underway } \\
\text { Not useful }\end{array}$ & 10 & 9 & 17 & 10 & 9 & 40 \\
$\begin{array}{l}\text { Number of respondents } \\
\text { Null }\end{array}$ & $\frac{59}{100 \%}$ & $\frac{45}{100 \%}$ & $\frac{33}{100 \%}$ & $\frac{62}{100 \%}$ & $\frac{45}{100 \%}$ & $\frac{20}{100 \%}$ \\
\hline
\end{tabular}

Manufacturers' Attitudes Concerning Selected Types of ID Reports.

Manufacturer's Opinion Mkts. Brochures Methods Bldgs.

\begin{tabular}{lcccc}
\hline $\begin{array}{l}\text { Very useful } \\
\text { Somewhat useful }\end{array}$ & 13 & 4 & 38 & 14 \\
Not useful unless area & 36 & 14 & 34 & 20 \\
$\begin{array}{l}\text { presently being con- } \\
\text { sidered }\end{array}$ & 8 & 37 & 0 & 37 \\
Not useful & $\frac{43}{100 \%}$ & $\frac{45}{100 \%}$ & $\frac{28}{100 \%}$ & $\frac{29}{100 \%}$ \\
& 53 & 49 & 29 & 35 \\
\hline
\end{tabular}

Manufacturers' Attitudes Toward ID Unsolicited Reports By Size of Company

\begin{tabular}{|c|c|c|c|c|c|c|c|c|c|}
\hline \multirow[b]{2}{*}{ Manufacturer's Opinion } & \multicolumn{3}{|c|}{ Market } & \multicolumn{3}{|c|}{ Bldgs. } & \multicolumn{3}{|c|}{ Methods } \\
\hline & L & $M$ & $\mathrm{~S}$ & $\mathrm{I}$ & $M$ & $\mathrm{~S}$ & $\mathrm{~L}$ & $M$ & $\mathrm{~S}$ \\
\hline Very useful & 0 & 18 & 50 & 5 & 13 & 50 & 46 & 28 & 33 \\
\hline $\begin{array}{l}\text { Somewhat useful } \\
\text { Not useful unless }\end{array}$ & 47 & 18 & 20 & 24 & 25 & 0 & 23 & 43 & 44 \\
\hline $\begin{array}{l}\text { project being } \\
\text { considered }\end{array}$ & 6 & 18 & 0 & 43 & 38 & 17 & 0 & 0 & 0 \\
\hline Not useful & $\frac{47}{100 \%}$ & $\frac{45}{100 \%}$ & $\frac{33}{100 \%}$ & $\frac{29}{100 \%}$ & $\frac{25}{100 \%}$ & $\frac{33}{100 \%}$ & $\frac{31}{100 \%}$ & $\frac{28}{100 \%}$ & $\frac{22}{100 \%}$ \\
\hline
\end{tabular}

$\begin{array}{lllllllllll}\text { Number of respondents } & 32 & 11 & 10 & 21 & 8 & 6 & 13 & 7 & 9\end{array}$ 
Manufacturers' Attitudes Toward Comparative Reports.

\begin{tabular}{lcccccc} 
& General & $\begin{array}{c}\text { Transnor- } \\
\text { tation }\end{array}$ & Power & Labor & raxes \\
\hline $\begin{array}{l}\text { Very useful } \\
\text { Somewhat useful }\end{array}$ & 39 & 29 & 30 & 38 & 37 \\
$\quad \begin{array}{l}\text { Not useful unless } \\
\quad \text { nroject considered }\end{array}$ & 56 & 21 & 22 & 21 & 42 \\
$\quad \begin{array}{l}\text { Not useful } \\
\text { Number of respondents }\end{array}$ & $\frac{29}{100 \%}$ & $\frac{43}{100 \%}$ & $\frac{37}{100 \%}$ & $\frac{35}{100 \%}$ & $\frac{16}{100 \%}$ \\
\end{tabular}

Manufacturers' Attitudes Toward Comparative ID Reports

By Size of Company.

\begin{tabular}{lccc} 
Manufacturer's Opinion & Large & Medium & Small \\
\hline Very useful & 26 & 33 & 70 \\
$\quad$ Somewhat useful & 26 & 33 & 70 \\
$\begin{array}{l}\text { Not useful unless project } \\
\text { being considered } \\
\text { Not useful }\end{array}$ & 0 & 22 & 0 \\
& $\frac{47}{100 \%}$ & $\frac{11}{100 \%}$ & $\frac{10}{100 \%}$ \\
Number of respondents & 19 & 9 & 10
\end{tabular}

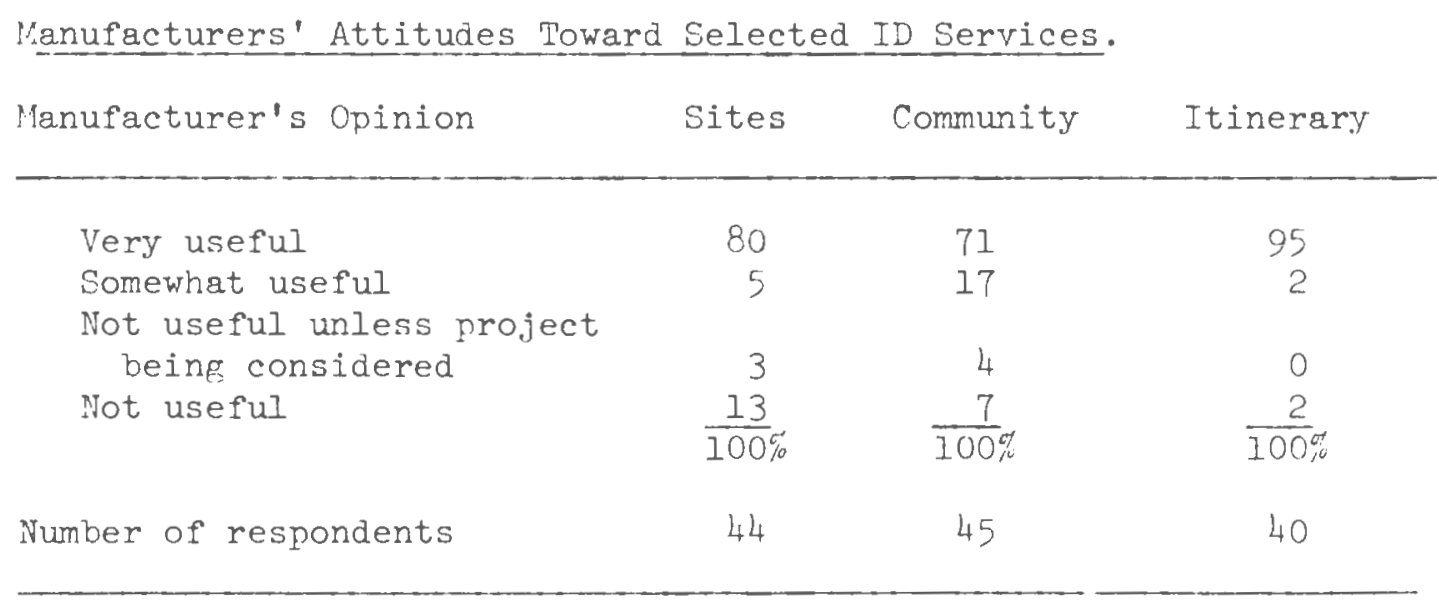


ADPEIDI: II

DAUTIOA DARA BA.CE
Ponulation

(projected)

(projected)

Tacial Compostion:
$1050 \ldots .40,100$

$1960 \ldots .41,132$

$1970 \ldots .43,756$

$1080 \ldots .45,001$

$1090 \ldots .45,750$

$2000 \ldots .47,350$

Faunton

Count $y$

c.tate

$\frac{1070}{43,756}$
444,301
$5,689,170$

444,301

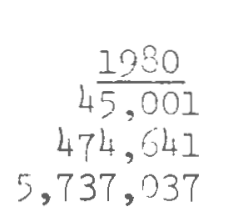

70-80

$\frac{c^{\prime} \text { Chance }}{2.8}$

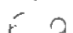

0.8

Dducation:

Yedian School Years Completed

Taunton 10.7

County 10.2

State 12.2

Ircome:

Per Capita Income.

$\begin{array}{lccc} & \frac{1060}{2,823} & 1077 & \frac{9}{1071} \\ \text { Maunton } & 2,936 & 5,004 & 66.9 \\ \text { County } & 2,407 & 5,026 & 70.4 \\ \text { State } & 3,407 & \end{array}$

$70-80$

\% Chanre

28.2

16.6

$\frac{396.2}{2.8}$ 
Labor Force:

$\begin{array}{lrrr} & & & 70-80 \\ \text { Labor Force } & \frac{1970}{8,325} & \frac{1980}{21,376} & \frac{\% \text { Change }}{16.7} \\ \text { Fmployment } & 17,556 & 19,682 & 12.1 \\ \text { Unemployment } & 772 & 1,694 & 119.4 \\ \text { Unemployment } & 4.2 & 7.9 & 88.1\end{array}$

lunicinal Finances:

\begin{tabular}{|c|c|c|}
\hline Assessed Valuation $(\$ 000)$ & $\frac{1980}{127,950}$ & $\frac{1981}{433,135}$ \\
\hline $\begin{array}{l}\text { Actual Tax Rates } \\
\text { (Per } \$ 1,000)\end{array}$ & 116.00 & 35.47 \\
\hline Assessment Ratio (\%) & 40 & 98 \\
\hline Full Value Tax Rate & 47.39 & 34.98 \\
\hline Massachusetts: & 1981 & \\
\hline Actual Tax Rates & $\overline{61.65}$ & \\
\hline Assessment Ratio & 61 & \\
\hline 11 Value Tax $R$ & & \\
\hline
\end{tabular}

Taunton's Moody Rating: A

Housing:

\begin{tabular}{|c|c|c|c|}
\hline Dwelling Units & $\frac{1970}{13.770}$ & $\frac{1980}{16,770}$ & $\begin{array}{l}70-80 \\
\% \text { Change } \\
21 . \overline{8}\end{array}$ \\
\hline Population Per & & & \\
\hline Unit & 3.1 & 2.7 & \\
\hline l-Unit & 6,981 & 7,657 & 9.7 \\
\hline $\begin{array}{l}2 \text { Units or more } \\
\text { Mobile Homes/ }\end{array}$ & 7,474 & 8,673 & 16.0 \\
\hline Trailers & 194 & 403 & 107.7 \\
\hline $\begin{array}{l}\text { Taunton } \\
\text { County } \\
\text { State }\end{array}$ & Dwelli & $\begin{array}{l}\frac{\text { Init } \%}{21.8} \text { Ch } \\
19.3 \\
16.8\end{array}$ & \\
\hline
\end{tabular}


Land Use:

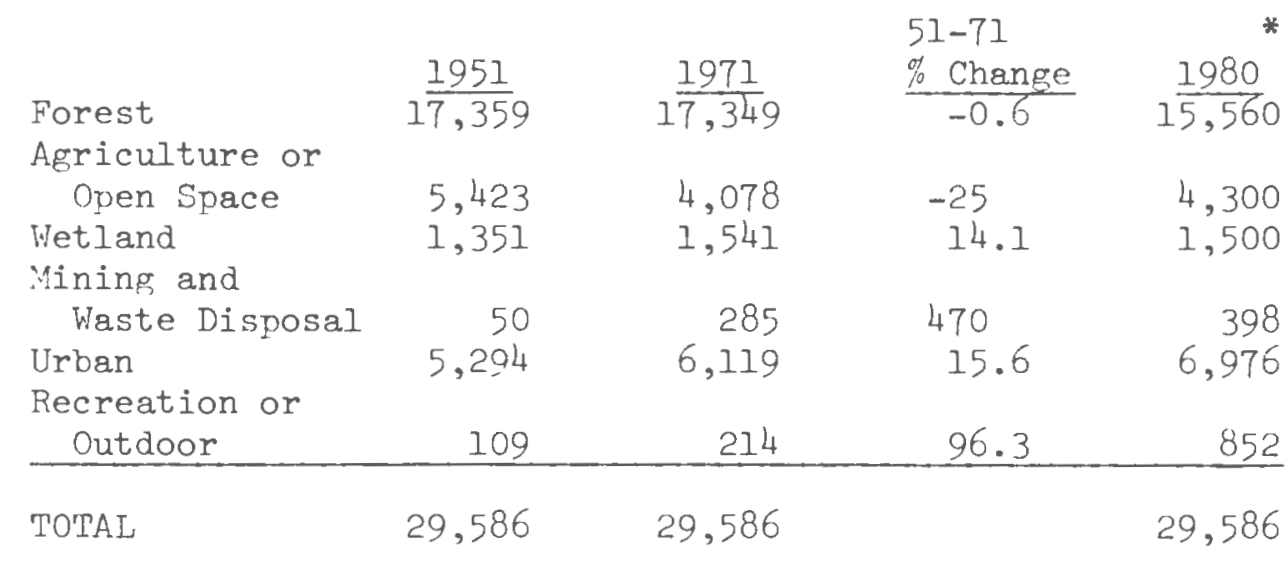

*Whereas McConnell Land Use Data was used for 1951 and 1971 data, the 1980 figures were estimated from the Open Space Master Plan for the City of Taunton. Much of the forest acerage in 1971 were categorized as recreation or outdoor in 1980.

All data in this Appendix comes from Data Base For The City of Taunton, prepared by the Southeastern Regional Planning and Economic Development District in 1982. This data base was used in preparing Southeastern Massachusetts Fact Book, 1982. 
EDA Grants to Municipalities for Industrial Park Development - Southeastern Massachusetts -

Fall River:
North Attleborough
Plymouth
New Bedford
Wareham
Taunton

$$
\begin{aligned}
& 1968 \ldots \ldots \ldots \ldots+032,000 \\
& 1970 \ldots \ldots \ldots \quad 200,000 \\
& 1968 \ldots \ldots \ldots 20,000 \\
& 1972 \ldots \ldots \ldots \quad 294,000 \\
& 1978 \ldots \ldots \ldots 1,670,000 \\
& 1968 \ldots \ldots \ldots .393,000 \\
& 1969 \ldots \ldots \ldots \quad 517,000 \\
& 1977 \ldots \ldots \ldots \quad 419,000 \\
& 1973 \ldots \ldots \ldots \quad 15,000 \\
& 1974 \ldots \ldots \ldots . \quad 858,000 \\
& \ldots \ldots \ldots \quad 38,000 \\
& 1975 \ldots \ldots \ldots . \quad 521,000 \\
& \text {....... 94,000 } \\
& 1979 \ldots \ldots \ldots 1,687,000 \\
& \$ 7,758,000
\end{aligned}
$$

Source: Southeastern Íassachusetts Regional Planning and Economic Development District. 1980 Annual Report and 1981 Program Projection of the Overall Economic Development Program, June 1981. 


\section{COVENANTS and RESTRICTIONS}

Said covenants and restrictions are as follows:

1. Site plans and specifications must be submitted to the Corporation and its written approval must be obtained prior to all construction on the conveyed premises. Site plans must include surface drainage, building locations, parking areas, landscaping, roadways, entrances and exits.

2. Location of roads, road widths, road surfacing and construction standards, as well as water, sewer and utility installations, must comply with all municipal or State rules, order, ordinances or regulations governing such facilities or installations.

3. No buildings or other improvements may be erected, placed or altered on the conveyed premises unless building, structural and architectural plans and specifications have been first submitted to the Corporation, and its written approval thereof obtained.

4. All structures erected on the conveyed premises (and the word "structure" shall include anything which requires location on or attachment to the ground, but does not include pavements or planting) must be so located on the conveyed premises that each part thereof is set back at least the following distances:

a. One hundred (100) feet from any street, highway or road upon which the structure in question fronts (it being understood that the Corporation reserves the right to approve the direction which any structure will face).

b. Fifty (50) feet from any other boundary line of the conveyed premises or, if the conveyed premises include two or more contiguous subdivision lots, from the exterior boundary of such lots.

If a site plan is submitted to the Corporation which shows the location of a proposed structure and said plan is approved in writing by the Corporation and then erection of said structure at the location shown on the site plan is begun and continues for ninety $(90)$ days without the institution of a suit to enjoin said construction on the ground that it violates the minimum set-back provisions of this subparagraph, it shall be conclusively presumed (against anyone to whom the benefits of this subparagraph runs) that the minimum set-back provisions have been complied with.

5. The area of the conveyed premises covered by buildings shall at no time exceed $50 \%$ of the total area of the conveyed premises.

6. No building or structures shall be erected or maintained except the same shall have exterior walls faced with brick, precast concrete, metal panels, or other equally aesthetically acceptable material approved by the Corporation or its successors as to color, permanence and architectural conformity with a garden-type industrial park, nor shall any buildings or structures be erected, or exterior structural alterations or additions made except pursuant to plans first approved in writing by the Corporation or its successors as to landscaping, and architectural conformity to a garden. type industrial park, which approval shall not be withheld unreasonably. Reasonable care shall be used to maintain the exterior appearance of said premises and all structures thereon in accordance with such plans.

7. The conveyed premises shall not be used or occupied at any time for any purpose other than the purpose of corporate headquarters, services industries, manufacturing, processing. wholesaling, distribution, and jobbing or warehousing which is in connection with on site manufacturing processing, wholesaling and distribution; or for the purpose of operating a business of a nature kindred to the ones specified.

8. Among those uses of the conveyed premises which are prohibited are residential uses and commercial uses of a retail nature except, in the latter case, such uses as may be incidental and of an insubstantial nature in comparison with the permitted commercial use of the premises; provided that any such exceptional retail use shall nevertheless be conducted only with the prior written ap. proval of the Corporation. 
9. No obnoxious or offensive trade or activity shall be carried on, nor shall anything be done on the conveyed premises which may be or may become an annoyance to the occupants of the other premises in the area, including but not limited to unsightliness, excess emission of odors, waste, dust, fumes, smoke, noise, vibration, heat, glare or toxic gases.

10. No waste material or refuse shall be dumped upon or permitted to remain upon any part of the conveyed premises outside of buildings constructed thereon. In addition, the conveyed premises shall not be used for any industry whose primary business requires industrial sewage unless the governing municipal and State bodies authorize the use of the available sewage disposal facilities. All liquid or solid wastes must be treated to conform with applicable standards of the Massachusetts Department of Health or any other regulations of any governing municipal or state body. Nothing in this paragraph shall prevent the owner of any portion of the premises from constructing thereon a "settling pond" to receive materials discharged in the process of the manufacture of its product so long as said pond or its use is neither unsightly, offensive, unsanitary or in violation of any state or municipal regulation or order.

11. Any and all parking, including parking for visitors, employees or customers shall be "off street" and there shall be no less than one (1) parking space for every two (2) workers employed on the conveyed premises. Parking shall be permitted between the front lot line and the building or buildings and out to a line forty (40) feet from the front lot line. All roads and parking areas shall have a minimum surfacing of asphaltic concrete. Curbings shall be installed in all parking areas between the front lot line and the building set-back line.

12. Any and all loading, unloading or deliveries on the premises shall be "off-street", located at the rear or sides of the building. All loading or unloading areas shall have a minimum surfacing of asphaltic concrete with curbing. Curbings shall be installed in all loading and unloading areas between the front lot line and building set-back line.

13. No materials or supplies shall be stored or permitted to remain on any part of the conveyed premises outside the buildings constructed thereon.

14. The Zoning and Building Code regulations in effect from time to time shall be deemed as minimum requirements.

15. The area between the buildings and the property lines is to be used either for open land. scape and green areas, or for off-street parking. The area is to be landscaped attractively with lawns, trees, shrubs, etc. according to plans first approved by the Corporation. Any landscaped area shall be properly maintained in a sightly and well-kept condition.

16. Every owner of a portion of the premises shall maintain the roads and structures within his own property in good condition, and the grounds, such roads, parking areas, grass, shrubs and trees in a clean and tidy manner.

17. No fence or permanent construction shall be permitted between the building line and any street, highway or road or elsewhere on the parcel, over three (3) feet in height of an opaque nature without prior consent of the Corporation.

18. No billboards or advertising sign, other than those identifying the main business and products of the firm occupying the premises shall be permitted. All such signs shall be approved by the Corporation. No unshaded, flashing or open lights shall be allowed on such signs.

19. No part of the conveyed premises shall be further sub-divided by any owner nor any portion thereof transferred or conveyed so as to cause the remainder thereof to fail to comply with any pro. vision of these restrictions.

20. In the event that the owner of any portion of the premises shall intend to sell the conveyed premises, or any portion thereof, it shall first offer to reconvey the same unto the Corporation on the following terms: 
a. If there shall be no building on the land, the price shall be the same price per square foot at which the premises were originally sold by the Corporation to the original grantee.

b. If a facility is situated upon said land, the Corporation shall have the first refusal to purchase said land and facility at the same price and other terms which any prospective purchaser may be willing to pay as indicated by a written offer submitted by said prospective purchaser.

c. If the Corporation within thirty (30) days after receipt of notice of such offer does not agree to meet it, the owner shall be free to sell to the offeror. This right of first refusal shall not be binding on any mortgagee which acquires title to said premises or any portion thereof through foreclosure or deed in lieu thereof and shall not be operative in the event of any foreclosure by sale with respect to the premises or any portion thereof.

21. If, after the expiration of two (2) years from the execution of a deed by the Corporation to any grantee for a portion of the premises, such grantee or any subsequent owner of the conveyed premises shall not have begun, in good faith, with reasonably complete arrangements to carry through to completion, the construction of a building on the conveyed premises approved by the Corporation under the foregoing restrictions and provisions, the Corporation shall have an option to repurchase the site for the price paid by the grantee or owner. The Corporation may extend the foregoing two (2) year period whenever it deems it desirable to do so. The Corporation's aforesaid option must be exercised in writing within one (1) year after it accrues; otherwise the option shall expire.

22. All and each of the above restrictions and covenants herein contained shall remain in effect for the period specified above, except that they may be amended by a proper vote of the Corporation provided that the amendment imposes no more onerous conditions on any existing owner.

23. The Corporation may from time to time by written instrument in recordable form grant variances from or waivers of any one or more of the foregoing restrictions and covenants where, in the opinion of the Corporation, as certified in the instrument, desirable relief can be granted without substantial detriment to the development of the premises as a garden-type industrial park and without substantial detriment to the portions thereof theretofore built upon.

24. The Corporation may from time to time by written instrument in recordable form grant ap. proval to an existing or proposed use or structure or certify as to compliance with any of the preceding covenants and restrictions, and any such instrument, when duly recorded, shall be con. clusive evidence of such approval and/or compliance binding upon all who may be entitled to en. force these restrictions. Any such written approval or certificate of compliance shall be signed by the President of the Corporation or by such other officer as the Corporation may designate by vote duly adopted and evidenced by a certificate of vote duly recorded with the Bristol County North District Registry of Deeds. At such time as the Corporation shall cease to own any portion of the premises, it shall designate by instrument duly executed and suitable for recording one or more of the record owners of a portion or portions of the premises to succeed to all of the functions and duties of the Corporation under these covenants and restrictions, such designation to become effective upon recording of such instrument and of the written acceptance thereof by such designated owner or owners with said Registry of Deeds. 
Executed as a sealed instrument this 14th day of April, 1978.

TAUNTON DEVELOPMENT CORPORATION

By:

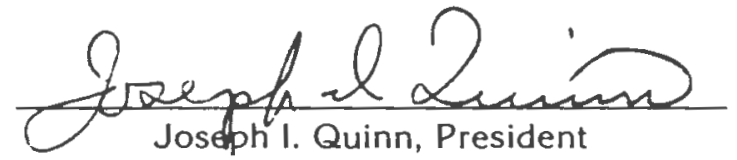

By:

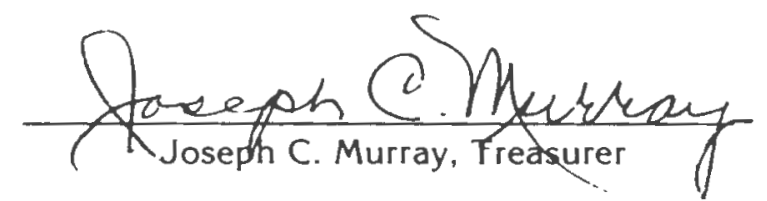

Attest:

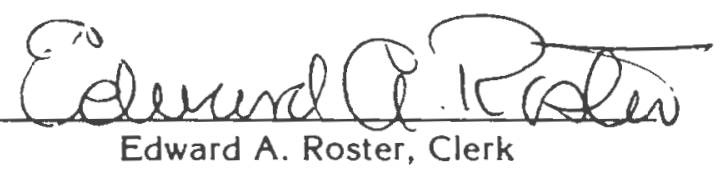

Edward A. Roster, Clerk

\section{COMMONWEALTH OF MASSACHUSETTS}

Bristol, ss.

April 14, 1978

Then personally appeared before me the above named Joseph I. Quinn, President of said Corporation, and acknowledged the foregoing to be the free act and deed of said Corporation, before me.

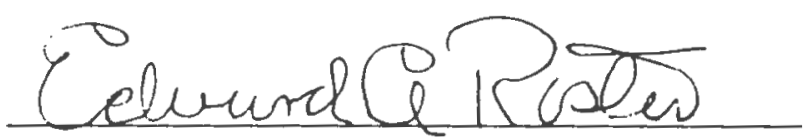

Edward A. Roster, Motary Public

My Commission Expires: March 30, 1984 
FOOTNOTES

1. Robert E. Boley, "Industrial Districts: Principles in Practice," Technical Bulletin No. 44, Washington, December 1962, pp. 10-11.

2. J.R. Lee and G.K.H. Wong, An Analysis of Organized Industrial Districts (Menlo Park: Stanford Research Institute, 1958), p. 8.

3. Ibid.

4. Barry M. Moriarty, Industrial Location and Community Development (Chapel Hill: University of North Carolina Press, 1980), D. 71.

5. Ibid., p. 70 .

6. Dick Howard, ed., Guide to Industrial Development (Englewood Cliffs, N.J.: Prentice-Hall, Inc., 1972), p. 196.

7. William A. McAloon, interview held at Taunton Industrial Develonment Commission Office, Taunton, Massachusetts, February 25, 1982.

8. This situation may develop in isolated rural communities but is unlikely to occur in metropolitan areas.

9. For a look at the consequences of poor planning see the article Richard Muther, "How to Develop Industrial Slums," Technology Review, February/ March 1981, pp. 10-11. Also see: Real Estate Research Corporation, The Costs of Sprawl (Washington: Council on Environmental Quality, the Department of Housing and Urban Development, and the Environmental Protection Agency, April 1974).

10. R.I. Statewide Planning Program, Industrial Zoning Guidelines, (Providence, R.I., October 1980), p. 10.

11. James E. Tonere, Industrial Development In A Rapidly Growing Community (Boston: Financial Publishing Company, 1972), pp. 16-18.

12. Ibid., pp. 18-19.

13. Ibid., pp. 19-22.

14. For examples see: Moriarty Industrial Location and Community Development, 89-120; Howard Guide to Industrial Development, 480-485; Robert Foster, "Economic And Quality of Life Factors In Industrial Location Decisions," Social Indicators Research, July 1977, pp. 247-265.

15. Foster, "Economic And Quality of Life Factors In Industrial Location Decisions," 247-265. 
16. According to John Dyckman the intangible considerations more than occasionally include decisions based on happy hour conversations between corporate heads. John Dyckman, John Hopkins Center for Metropolitan Planning and Research, Johns Hopkins University. Lecture at the University of Rhode Island, February 25, 1982.

17. Alfred J. Watkins, The Practice Of Urban Economics (Beverly Hills: Sage Publications, 1980), pp. 17-18. See :

18. "More elbowroom for the electronics industry," Business Week, March 10, 1980, pp. 94-100.; Foster, "Economic And Quality Of Life Factors In Industrial Location Decisions," 247-265.

19. Information on these industries is taken from Watkins Urban Economics, 43-48.

20. Watkins Urban Economics, 60.

21. Foster, "Economic And Duality of Life Factors In Industrial Location Decisions," 252.

22. Information on these industries is taken from Watkins Urban Economics, $43-48$.

23. Ibid., p. 47 .

24. Ibid., pp. 60-64.

25. Howard Guide to Industrial Development, 91.

26. Moriarty Industrial Location and Community Development, 100-113.

27. Ibid., p. 102 .

28. David Gordon, "Capitalism and the Roots of the Urban Crisis," in R.E. Alcaly and D. Mermelstein (eds.) The Fiscal Crisis of American Cities (New York: Vintage, 1976), pp. 103-104.

29. Moriarty Industrial Location and Community Development, 181-192.

30. Ibid., p. 187 .

31. See: Watkins Urban Economics, 74-77.; Moriarty Industrial Location and Community Development, 246-256.; Howard Guide to Industrial Development, 324-330.

32. Bennett Harrison and Sandra Kanter, "The Great State Robbery," Working Papers for a New Society, 4 (Spring, 1976), n. 62.

33. "A Counterattack in the War Between the States," Business Week, June 21, 1976, p. 71.

34. Urban Land Institute, Industrial Development Handbook (Washington: Urban Land Institute, 1975), p. 192. 
35. Maria Gooch, Fconomic Development Coordinator, interview at Southeastern Regional Planning and Economic Development Listrict, Marion, Massachusetts, February 16, 1982.

36. ULI Handbook, 190-193.

37. Ibid., p. 193.

38. This sequence has been adapted from Howard Guide to Industrial Development, $41-42$.

39. For an understanding of how "industrial slums" are created see Muther, "How to Develop Industrial Slums," 10-1l.

40. Particularly if infrastructure improvements are needed.

41. Maria Gooch interview.

42. R.I. Statewide Planning Program, "Industrial Zoning Guidelines," Technical Paper Number 92 (Providence, R.I., October 1980), pp. 7-9.

43. See earlier discussion of location theory.

44. Indeed this is the argument which "free market" proponents, who frown on the government sponsored part concept, expound.

45. As mentioned in earlier discussion of location theory.

46. Howard Guide to Industrial Development, 45.

47. H. James Brown, Chairman, City and Regional Planning Harvard University. Lecture at University of Rhode Island, April 14, 1982.

48. See ULI Handbook, 76-77 for Cabot, Cabot, and Forbes criteria.

49. R.I. Statewide Planning Program, "Industrial Zoning Guidelines," Technical Paper Number 92, p. 3.

50. Ibid., p. 30.

51. U.S. Department of Housing and Urban Development, Innovative Zoning: A Local Officials Guidebook (Washington, August 1978), p. 15 .

52. Ibid., pp. 15-16.

53. Ibid., pp. 10-12.

54. For example, management and maintenance problems.

55. Muther "How to Build Industrial Slums," Technology Review, 11.

56. ULI Handbook, 30 .

57. Ibid., p. 98 .

58. Ibid. 
59. Kevin Lynch, Site Planning (Cambridge, Massachusetts: The M.I.T. Press, 1971), pp. 51-58.

60. For further information on these laws see: Moriarty Industrial Location and Community Development, 227-243.; Donald G. Hagman, Public Planning And Control of Urban And Land Development (St. Paul: West Publishing Co., 1980), pp. 1168-1253.

61. ULI Handbook, 78 .

62. Ibid.

63. Ibid., p. 79.

64. Obviously local community leaders would be very involved in making there determinations.

65. Howard Guide to Industrial Development, 135-136.

66. Most of these recommendations were suggested three decades ago by T.K. Pasma, "Organized Industrial Districts in the United States," U.S. Department of Commerce Bulletin, (Washington, June 1954), n. 45.

67. Lynch Site Planning, 289-295.

68. ULI Handbook, 147.

69. Ibid., 146.

70. According to Howard Guide to Industrial Development, p. 61, a 1963 study showed that $70 \%$ of industrial parks utilize both leasing and sales. Only $8 \%$ used leasing-only, and $21 \%$ used slaes-only.

71. Howard Guide to Industrial Development, 66.

72. Obviously this is more important to the private develoner than to the public sponsor.

73. Tonere Industrial Development In A Rapidly Growing Community, 62.

74. ULI Handbook, 170.

75. Ibid.

76. Tonere Industrial Development In A Rapidly Growing Community, 74.

77. ULI Handbook, 170.

78. For further information on REITs see: ULI Handbook, 171.; Anthony J. Yudis, "REIT's making a strong comeback, "The Boston Globe, April 25, 1982, p. A-33.

79. Moriarty Industrial Location and Community Develonment, 276.

80. Ibid., ก. 279. 
81. Ibid.

82. David Kolzow, "Should Industrial Land Be Preserved?," Urban Land, March 1981, pp. 13-15.

83. Howard Guide to Industrial Development, 294.

84. It is not too early to begin informal marketing once the developer has purchased an option on a tract of land.

85. Tonere Industrial Development In A Ranidly Growing Community, 32.

86. ULI Handbook, 189.

87. Ibid., p. 190.

88. Ibid., p. 189.

89. Ibid.

90. Moriarty Industrial Location and Community Development, 344.

91. Ibid., p. 345 .

92. Ibid., p. 344.

93. Ibid., p. 343.

94. Ibid., p. 347 .

95. This study was based on responses from 70 manufacturing companies concerning 71 plant locations, and was published by the Office of Industrial Development Studies, University of Missouri, in October of 1970. It is republished in Howard Guide to Industrial Development, 199-221.

96. Larry Laughlin and Shari Polikoff, "No Right or Wrong Way to Attract Industry," Taunton Daily Gazette, May 18, 1974, p. 1.

97. Information on history of Maunton comes from: Encyclopedia Americana Volume 26, (Danbury Ct.: Grolier Inc., 1981), p. 314; Taunton, lass. Industrial Profile, p. 2.

98. Southeastern Regional Planning and Economic Development District, 1980 Annual Report and 1981 Program Projection of the Overall Economic Development Program, June 1981, p. 24.

99. Southeastern Regional Planning and Economic Development District, I-495 Areawide Approach to Growth, October 1978, p. 2.

100. Ibid., p. T-3.

101. Massachusetts office of State Planning, Nassachusetts Growth Policy Report, September 1977 , D. 26. 
102. Inid.

103. Ibid.

104. SPPEDD Annual Report, 12-13.

105. Ibia.

106. Ibid., D. 14 .

107. Ibid.

108. Ibid.

109. Ibid., p. 28.

110. Ibid., ค. 34.

111. Ibid.

112. Ibid.

113. Ibid., p. 51.

114. Ibia., p. 53 .

115. Ibid., n. 55.

116. John Powers, "High tech lobby's fast-lane clout," Boston Globe, April 18, 1982, p. A-1.

117. Thomas J. Murray, "Whether Silicon Valley?," Dun's Business Nonth, February 1982, F. 79.

118. "High tech lobby's fast-lane clout," Boston Globe, p. A-4.

119. Ibid.

120. Ronald Rosenberf and Ben Bradee, "40 million high-tech 'college' nroposed," Boston Globe, April 29, 1982, p. 38.

121. Larry Laughlin and Shari Polikoff, "Local People Key to Success," Taunton Daily Gazette, March 30, 1974, D. 1 .

122. Jim Souza, "City Industrial Comission Reorganized," Taunton Daily Gazette, Hay 27, 1970, D. 1; "Industrial Commission Picks Retired Colonel as Secretary," maunton Daily Gazette, September 4, 1970, p. 1. Chase salary: \$8,000 a year.

123. "James Chase Resigns from Industrial Panel," Taunton Daily Gazette, April 20, 1971, R. I; "UcAloon Selection Wins Flood Praise," Taunton Daily Gazette, December 29, 1971, p. 1. McAloon salary: $\$ 10,000$ a year.

124. The variance was denied. "Variance Opposed By IIDC," Taunton Daily Gazette, October 25, 1972, p. 1 . 
125. The camp nrocessed as many as 40,000 men weekly for overseas duty. William A. McAloon. "The Making of an Industrial Park," Northeastern Industrial World, December 1978, reprint - pages unnumbered.

126. Aleixo also served as a State Representative.

127. "Local Peonle Key to Success," Taunton Daily Gazette, March 30, 1974, p. 1 .

128. Tbid., p. 3 .

129. Ibid.

Fall River was and still remains one of Taunton's biggest comnetitors in attracting incustry.

130. Ibid.

131. William McAloon interview.

132. William McAloon interview.

133. "Industrial Park $\$ 15,000$ Grant Okayed by EDA," Taunton Daily Gazette, June 23, 1973, p. 1 .

134. By this time the size was down to 437 acres - determined in part by a concern for aquifers, wells and ponds in the area. Final boundaries were "drawn with a ruler" at a meeting with various city and state of ficials. This information comes from the William licAloon interview.

135. "Dever Land Bill Signed by Sarge," Taunton Daily Gazette, June 25, 1974, p. 1.

136. Ibid.

137. SRPEDD, 1980 Annual Report and 1981 Program Projection, p. 12.

138. William McAloon interview.

139. William McAloon, "The Making of an Industrial Park," Northeastern Industrial World, December 1978, unnumbered.

140. Ibid.

141. "No Right or Wrong Way to Attract Industry," Taunton Daily Gazette, Nay 18,1974, p. 9.

142. Ibid.

143. William lcAloon interview.

144. William McAloon interview.

145. William McAloon interview. According to McAloon this site would have necessitated construction of a state road to provide access to the proposed industrial park. 
146. William McAloon interview.

147. "City Unit Gets $\$ 50,000$ Grant," Taunton Daily Gazette, May 31, 1974, p. 3 .

148. Kathy Morgan, "Industrial Park linked to downtown," Taunton Daily Gazette, 1981 Progress Edition, p. 32A.

149. Ibid.

150. Ibid.

151. Ibid.

152. Ibid.

153. "Control of Industrial Park Changes Hand," Taunton Daily Gazette, October 20, $1976, \mathrm{p} .3$.

154. EDA guidelines had changed proportions from 50-50 to 70-30.

155. By the time the TDC was given control the city had already assumed responsibility for the major infrastructure improvements reguired in Phase One.

156. Revenue obtained from the sale of land would be used to finance development of the next phase.

157. "The Making of an Industrial Park," Northeastern Industrial World, December 1978, unnumbered.

158. This name was also used in Attleboro and other communities. "Students to Name Industrial Park," Taunton Daily Gazette, September 16,1975, p. 2 .

159. See earlier history of Taunton.

160. "The Haking of an Industrial Park," Northeastern Industrial World, December 1978, unnumbered.

161. Ibid.

162. "Industrial Park linked to downtown," Taunton Daily Gazette, 1981 Progress Edition, p. 32A.

163. Ibid.

164. "The Making of an Industrial Park," Northeastern Industrial World, December 1978, unnumbered.

165. "Industrial Park linked to downtown," Taunton Daily Gazette, 1981 Progress Edition, D. 32A.

166. Ibid.

167. "The Making of an Industrial Park," Northeastern Industrial World, December 1978, unnumbered. 
168. Ibid.

169. SRPEDD, 1980 Annual Report and 1981 Program Projection, D. 13.

170. An additional 9,000 lineal feet of roadway.

171. William l!cAloon interview.

172. "Pepsi company to locate here," Taunton Daily Gazette, March 16 , 1982, n. 1.

173. "Blending Industrial Park With the Environment," Taunton Daily Gazette, February 29, 1980, p. 28A.

174. Richard Bettencourt interview.

175. William McAloon interview.

176. William McAloon interview.

177. William McAloon interview.

178. "Industrial Park linked to downtown," Taunton Daily Gazette, 1981 Progress Edition, p. 32A.

179. Mike Williams, "New Acres for industry," Taunton Daily Gazette, March 3, 1982, p. 21A.

180. William McAloon interview.

181. William McAloon interview.

182. "Come East, high tech," Boston Globe, April 6, 1982, p. 54.

183. Ibid.

184. Vicki-Ann Gay, "Hi-tech firms lured here," Taunton Daily Gazette, April 30, 1982, p. 1.

185. Ibid. 
Alcaly, R.I. and Mermelstein, D. (eds.). The Fiscal Crisis of American Cities. New York: Vintage, 1976, np. 82-112.

Bredo, William. Industrial Estates - Tool For Industrialization. International Industrial Development Center, Sanford Research Institute. Glencoe, Illinois: The Free Press, 1960.

Burchell, Robert $W$. and Hughes, James. Planned Unit Development: New Communities American Style. New Brunswick, N.J.: Transaction Books, 1972.

Hagman, Donald G. Public Planning And Control of Urban And Land

Development. St. Paul: West Publishing Co., 1980.

Howard, Dick (ed.). Guide to Industrial Development. Englewood Cliffs, N.J.: Prentice-Hall, Inc., 1972.

Lee, J.R. and Wong, G.K.H. An Analysis of Organized Industrial Districts. Menlo Park, California: Stanford Research Institute, 1958.

Lynch, Kevin. Site Planning 2nd ed. Cambridge: The M.I.T. Press, 1971.

Moriarty, Barry M. Industrial Location and Community Development. Chapel Hill: The University of North Carolina Press, 1980.

Tonere, James E. Industrial Development In A Rapidly Growing Community.

Boston: Financial Publishing Company, 1972.

Urban Land Institute. Industrial Development Handbook. Community Builders Handbook Series. Washington, D.C.: The Urban Land Institute, 1975.

Watkins, Alfred J. The Practice Of Urban Economics. Beverly Hills: Sage Publications, 1980.

REPORTS AND ARTICLES

"A Counterattack in the War Between the States." Business Week, June 21, 1976, p. 71.

Boley, Robert E. "Industrial Districts: Principles in Practice." Technical Bulletin No. 44, Washington D.C., December 1962.

"Brain drain: A worry for New England." Business Week, October 25, 1976 , p. 32 .

Council on Environmental Quality. The Growth Shapers, Washington, D.C., l.hy 1976.

Dotson, Borne and Epstein, Herbert. "Pare Down That Zoning Ordinance." Planning volume 46, number 1 (January 1980), 16-18. 
Ebert, Ronald J. and Adam, Everett E. Jr. "The Iluman Factor in Facilities Location Planning." Business Horizons, November 1977, pp. 35-42.

Foster, Robert. "Economic And Quality of Life Factors In Industrial

Location Decision." Social Indicators Research, July 1977, pp. 247-265.

Hanushek, Eric A. and Song, Byung Nak. "The Dynamics of Postwar Industrial Location." The Review of Economics And Statistics, November 1978, pp. 515522 .

Harrison, Bennet and Kanter, Sandra. "The Great State Robbery." Working Papers for a New Society 4 (Spring 1976): 57-66.

Kolzow, David. "Should Industrial Land Be Preserved?" Urban Land, March 1981, pp. 13-15.

IfAloon, William A. "The Making of An Industrial Park." Northeastern Industrial World, December 1978.

Massachusetts Division of Fmployment Security. Taunton, Massachusetts Labor Area Mannower Information for Affirmative Action Programs - 1979, prepared by David R. Farmer.

Massachusetts Office of State Planning. City and Town Centers: A Program for Growth, The Massachusetts Growth Policy Report, September 1977.

"More elbowroom for the electronics industry." Business Week, March 10, 1980 , pp. 94-100.

Murray, Thomas J. "Whither Silicon Vallev?" Dun's Business Month, February 1982, pp. 79-80.

Muther, Richard. "How to Develop Industrial Slums." Technology Review, February/liarch 1981, no. 10-11.

New England Regional Commission. The New England Regional Plan: An Economic Development Strategy, Hanover, N.H.: University Press of New England, 1981.

"Organized Industrial Districts in the United States." U.S. Department of Commerce Bulletin, by T.K. Pasma, June 1954.

Real Estate Research Corporation, for CEQ, HUD, EPA. The Costs of Sprawl, April 1974.

R.I. Statewide Planning Program. Industrial Zoning Guidelines Technical Paper Number 92. Providence, R.I., October 1980.

Southeastern Regional Planning and Economic Development Commission. Interstate 495: Areawide Approach to Growth, October 197?.

- 1980 Annual Report and 1981 Program Projection of the Overall Economic Development Program, June 1981. 
- Southeastern Massachusetts Fact Book, i'ay 1982.

- State of The Region, 1981.

Taunton Development Corporation. Covenants and Restrictions, April 14 , 1978.

Taunton Industrial Development Commission. Build Your Future In The Winner's Circle - Taunton, Mass. Industrial Profile, 1979.

Urban Land Institute. "A Survey of Leveraging in Older Cities." Urban Land, December 1980, pp. 6-11.

- "Factors Shaping Development in the '80's." Urban Land, December 1981 , pp. 8-16.

U.S. Department of Housing and Urban Development. Innovative Zoning: A Local Officials Guidebook, Washington, D.C., August 1978.

- The Private Development Process: A Guidebook for Local

Government, Washington, D.C., 1979.

\section{NEWSPAPER ARTICLES}

"Atco Wire Inks Finance Papers." Taunton Daily Gazette, August 1, 1974 , p. 1 .

Black, Chris. "Legislators urge state land-sale fight." Boston Globe, March 27, 1982, p. 1.

"Census shows income shifts." Boston Globe, April 26, 1982, p. 7.

"City Unit Gets \$50,000 Grant." Taunton Daily Gazette, May 31, 1974 , p. 3.

"Come East, high tech." Boston Globe, April 6, 1982, p. 54.

"Control of Industrial Park Changes Hands." Taunton Daily Gazette, October 20, 1976, p. 3 .

"Dever Bill Passes, 38-0." Taunton Daily Gazette, June 13, 1974, p. 1.

"Dever Land Bill Gets Senate OK." Taunton Daily Gazette, June 11, 1974, p. 1.

"Dever Land Bill Saved by Aleixo." Taunton Daily Gazette, June 4, 1974, p. 1.

"Dever Land Bill Signed by Sarge." Taunton Daily Gazette, June 25, 1974 , p. 1 .

Dever Park Target Date is Set July 15." Taunton Daily Gazette, February 21, 1975, p. 1.

"Fewer firms, but coast trip seen success." Taunton Daily Gazette, April 29, 1982, p. 1.

Gay, Vicki-Ann, "Hi-tech firms lured here." Taunton Daily Gazette, April 30, 1982, p. 1 . 
Golden, Daniel. "Census: What the 170 s meant to Bay State." Boston Globe, April 21, 1982, p. 21.

Harrison, Bryan. "Optimism Expressed Concerning Industrial Development of Taunton." Tqunton Daily Gazette, January 26, 1971, .. I.

"Industrial Commission Picks Retired Colonel as Secretary." Taunton Daily Gazette, September 4, 1970, D. 1.

"Industrial Commission Reports 56 Prospects." Taunton Daily Gazette, May 6, 1972, p. 18.

"Industrial Park \$15,000 Grant Okayed by EDA." Taunton Daily Gazette, June 23, 1973, p. 1.

"James Chase Resigns From Industrial Panel." Taunton Daily Gazette, April 20, 1971, p. 1.

Jones, Ann T. "Route 495 brings changes to old Bay Road." Taunton Daily Gazette, March 3, 1982, p. 16A.

Kenlan, Joe. "Industrial Financing Authority Set." Taunton Daily Gazette, June 6, 1972, p. 1 .

Kennedy, MaryEllen. "Massachusetts has 'optimism'." Boston Clobe, March 9, 1982 , p. 56.

"King, 3-city unit on same hi-tech path." Taunton Daily Gazette, April 27, $1982, \mathrm{p} .1$.

Kuttner, Bob. "Taxachusetts? It's just a myth." Boston Globe, March 15, $1982, \mathrm{p} .11$.

Laughlin, Larry and Polikoff, Shari. "Local Feople Key to Success." Taunton Daily Gazette, March 30, 1974, p. 1 .

. "No Right or Wrong Way to Attract Industry." Taunton Deily Gazette, May 18, 1974, p. 1.

"McAloon Selection Wins Flood Praise." Taunton Daily Gazette, December 29 , 1971 , p. 1.

McGovern, Ted. "Raynham officials differ on Route 495 impact." Taunton Daily Gazette, March 3, 1982, p. IIA.

Merseth, Gale. "Letter to the Editor." Boston Globe, March 21, 1982, p. A-26.

Morgan, Kathy. "Industrial Park linked to downtown." Taunton Daily Gazette, 1981 Progress Edition, p. 32A.

"Pepsi company to locate here." Taunton Daily Gazette, March 16, 1982 , p. 1. 
Polikoff, Shari. "Blending Industrial Park With the Environment." Taunton Daily Gazette, February 29, 1980, p. 28 A.

Powers, John. "High tech lobby's fast-lane clout." Boston Globe, April 18, 1982, p. A-l.

Rosenberg, Ronald and Bradlee, Ben. "\$40 million high-tech 'college' proposed." Boston Globe, April 29, 1982, p. 1 .

"Sargent Delays on Dever Bil1." Taunton Daily Gazette, June 24, 1974, p. 1. Souza, Jim. "City Industrial Commission Reorganized." Taunton Daily Gazette, May 27, 1970, p. 1.

"Students to Name Industrial Park." Taunton Daily Gazette, September $16,1975, \mathrm{p} .2$.

"Tri-city 'invaders' safe in SF." Taunton Daily Gazette, April 26, 1982, p. 1 .

Trigoboff, Dan. "Taunton Industrial Park Project Already \$125,000 in Red." Taunton Daily Gazette, June 24, 1976, p. 1.

"20 companies view tri-city slide, display." Taunton Daily Gazette, April 28, 1982, p. 1 .

"Variance Opposed By TIDC." Taunton Daily Gazette, October 25, 1972, p. 1 .

Williams, Mike. "New acres for industry." Taunton Daily Gazette, March 3, 1982, p. 11A.

Yudis, Anthony J. "Brokers acknowledge it's getting harder to make a deal." Boston Globe, March 9, 1982, p. 53.

P. A33. - "REITs making a strong comback." Boston Globe, April 25, 1982 , - "The outlook for '82: 'It's not better than last year'." Boston Globe, March 9, 1982, p. 53.

\section{INTERVIEWS}

McAloon, William A. Fxecutive Director, Taunton Industrial Development Commission, Taunton, Massachusetts. Interview, February 25, 1982.

Bettencourt, Richard. Taunton Development Corporation, Taunton, Massachusetts. Interview, May 7, 1982.

Brown, H. James. Chaiman, City and Regional Planning, Harvard University. Lecture at University of Rhode Island, April 14, 1982.

Dyckman, John. Johns Hopkins Center for Metropolitan Planning and Research, Johns Hopkins University. Lecture at the University of Rhode Island, February 25, 1982. 
Gooch, Maria. Economic Develonment Coordinator. Interview at Southeastern Regional Planning, and Economic Develonment District, Marion, Massachusetts, February 16, 1982.

Heap, Russell. Planning, and Zoning Coordinator, Taunton, Massachusetts. Interview, May 7, 1982.

Johnson, Richard. Mayor, Taunton, Massachusetts. Interviews January 28, February 22, 1982 . 